\title{
Global distribution and climate forcing of carbonaceous aerosols
}

\author{
Serena H. Chung and John H. Seinfeld \\ Department of Chemical Engineering, California Institute of Technology, Pasadena, California, USA
}

Received 15 October 2001; revised 12 April 2002; accepted 13 June 2002; published 15 October 2002.

[1] The global distribution of carbonaceous aerosols is simulated online in the Goddard Institute for Space Studies General Circulation Model II-prime (GISS GCM II-prime). Prognostic tracers include black carbon (BC), primary organic aerosol (POA), five groups of biogenic volatile organic compounds (BVOCs), and 14 semivolatile products of BVOC oxidation by $\mathrm{O}_{3}, \mathrm{OH}$, and $\mathrm{NO}_{3}$, which condense to form secondary organic aerosols (SOA) based on an equilibrium partitioning model and experimental observations. Estimated global burdens of $\mathrm{BC}$, organic carbon (OC), and SOA are 0.22, 1.2 , and $0.19 \mathrm{Tg}$ with lifetimes of $6.4,5.3$, and 6.2 days, respectively. The predicted global production of SOA is $11.2 \mathrm{Tg} \mathrm{yr}^{-1}$, with $91 \%$ due to $\mathrm{O}_{3}$ and $\mathrm{OH}$ oxidation. Globally averaged, top of the atmosphere (TOA) radiative forcing by anthropogenic $\mathrm{BC}$ is predicted as +0.51 to $+0.8 \mathrm{~W} \mathrm{~m}^{-2}$, the former being for $\mathrm{BC}$ in an external mixture and the latter for $\mathrm{BC}$ in an internal mixture of sulfate, $\mathrm{OC}$, and $\mathrm{BC}$. Globally averaged, anthropogenic $\mathrm{BC}, \mathrm{OC}$, and sulfate are predicted to exert a TOA radiative forcing of -0.39 to $-0.78 \mathrm{~W} \mathrm{~m}^{-2}$, depending on the exact assumptions of aerosol mixing and water uptake by OC. Forcing estimates are compared with those published previously. INDEX TERMS: 0305 Atmospheric Composition and Structure: Aerosols and particles (0345, 4801); 0360 Atmospheric Composition and Structure: Transmission and scattering of radiation; 0365 Atmospheric Composition and Structure: Troposphere-composition and chemistry

Citation: Chung, S. H., and J. H. Seinfeld, Global distribution and climate forcing of carbonaceous aerosols, J. Geophys. Res., 107(D19), 4407, doi:10.1029/2001JD001397, 2002.

\section{Introduction}

[2] Anthropogenic-induced changes in the atmospheric abundance of tropospheric greenhouse gases and aerosols are estimated to make significant contributions to climate change over the next century [Houghton et al., 2001]. A number of studies have focused on the global distribution of sulfate aerosols [Langner and Rodhe, 1991; Luecken et al., 1991; Penner et al., 1994; Benkovitz et al., 1994; Chin et al., 1996; Feichter et al., 1996; Pham et al., 1996; Roelofs et al., 1998; Adams et al., 1999; Lohmann et al., 1999; Koch et al., 1999; Barth et al., 2000; Rasch et al., 2000] and their direct radiative forcing [Charlson et al., 1991; Kiehl and Briegleb, 1993; Taylor and Penner, 1994; Chuang et al., 1997; Feichter et al., 1997; Penner et al., 1997, 1998; Koch et al., 1999; Kiehl et al., 2000; Tegen et al., 2000; Adams et al., 2001]; fewer corresponding global threedimensional studies of carbonaceous aerosols exist [Liousse et al., 1996; Cooke and Wilson, 1996; Penner et al., 1998; Cooke et al., 1999; Kanakidou et al., 2000]. Several studies have addressed the direct radiative forcing of carbonaceous aerosols [Haywood and Shine, 1995; Haywood et al., 1997; Schult et al., 1997; Haywood and Ramaswamy, 1998; Myhre et al., 1998; Penner et al., 1998; Jacobson, 2000, 2001a, 2001b; Tegen et al., 2000; Koch, 2001].

Copyright 2002 by the American Geophysical Union. 0148-0227/02/2001JD001397
[3] Carbonaceous particles consist of a complex mixture of chemical compounds. Such particles are usually divided into two fractions, black (or elemental) carbon (BC) and organic carbon (OC). $\mathrm{BC}$ is a strong absorber of visible and near-IR light; therefore, $\mathrm{BC}$ concentrations are traditionally determined by light-absorption measurements of particles collected on filters [Lindberg et al., 1999]. In contrast, aerosol OC represents an aggregate of hundreds of individual compounds with a wide range of chemical and thermodynamic properties, making concentration measurements difficult using any single analytical technique. Instead, aerosol OC content is usually determined from the difference between total carbon and $\mathrm{BC}$ contents [Turpin et al., 2000].

[4] OC can be emitted directly into the atmosphere as products of fossil fuel combustion or biomass burning. This is called primary organic aerosol (POA). By contrast, secondary organic aerosol (SOA) is formed in the atmosphere as the oxidation products of certain volatile organic compounds (VOCs) condense on preexisting aerosols. Both anthropogenic and biogenic VOCs (BVOCs) can lead to $\mathrm{SOA}$; on a global scale, biogenic hydrocarbons are estimated to be the predominant source (except isoprene, which does not form aerosol upon oxidation [Pandis et al., 1991]). Experimental studies indicate that the aerosol yield (ratio of the mass of SOA formed to that of VOC reacted) exhibits a wide range of values for different parent hydrocarbons [Hoffmann et al., 1997; Odum et al., 1997; Griffin et al., 1999a, 1999b]. 
[5] Among global modeling studies on carbonaceous aerosols, only Liousse et al. [1996], Griffin et al. [1999b], and Kanakidou et al. [2000] have considered SOA. Liousse et al. [1996] estimated the global burden of SOA by assuming a constant aerosol yield of $5 \%$ for all biogenic species. On the basis of compound-specific, laboratoryderived aerosol yields, Griffin et al. [1999a] estimated the global production of biogenic SOA to lie in the range of 13-24 $\mathrm{Tg}_{\mathrm{yr}}^{-1}$, but their work did not directly employ a global three-dimensional transport model and did not include explicit calculation of the gas-particle partitioning of SOA into POA. Kanakidou et al. [2000] used a global chemical transport model with $\alpha$ - and $\beta$-pinene as representative of all biogenic hydrocarbons and considered only oxidation of the pinenes by $\mathrm{O}_{3}$ as a source of SOA. While they allowed for the partition of semivolatile oxidation products into the organic aerosol phase, they did not include transport of semivolatile products that remain in the gas phase. Kanakidou et al. [2000] estimated the production of SOA to be $17-28 \mathrm{Tg} \mathrm{yr}^{-1}$ for preindustrial times and $61-$ $79 \mathrm{Tg} \mathrm{yr}^{-1}$ for present-day. One issue, therefore, is understanding the relatively large discrepancy between the global SOA production estimates of Griffin et al. [1999a] and Kanakidou et al. [2000].

[6] In this work, we simulate the three-dimensional, global distribution of present-day and preindustrial carbonaceous aerosols, including BC, POA, and SOA. Oxidation of the five most important classes of biogenic hydrocarbons by $\mathrm{O}_{3}, \mathrm{OH}$, and $\mathrm{NO}_{3}$ is included to account for the different aerosol yield potentials of the reaction products of the parent molecules. The global distributions of $\mathrm{BC}, \mathrm{POA}$, and SOA are then used to estimate annual direct radiative forcing by all three classes of carbonaceous aerosols. Previous work has shown that the direct radiative forcing of aerosol $\mathrm{BC}$ depends importantly on the manner in which that $\mathrm{BC}$ is mixed with nonabsorbing aerosols such as sulfate [e.g., Jacobson, 2000; Myhre et al., 1998; Haywood et al., 1997]. Therefore, effects of the mixing state of the aerosol are considered.

\section{Model Description}

[7] Three-dimensional global transport of tracers is simulated online in the Goddard Institute for Space Studies General Circulation Model II-prime (GISS GCM II-prime) [Hansen et al., 1983; Rind and Lerner, 1996], together with imported fields of $\mathrm{OH}$ (C. Spivakovsky, personal communication, 1998), $\mathrm{O}_{3}$, and $\mathrm{NO}_{3}$ [Wang et al., 1998a].

\subsection{Tracer Model}

[8] The model includes a total of 37 prognostic species as tracers: 4 classes of primary carbonaceous aerosols, 5 reactive hydrocarbon groups, and 28 organic oxidation products.

\subsubsection{Primary Carbonaceous Aerosols}

[9] BC and POA are included as tracers in the model. For the purpose of representing wet scavenging, each of these two classes of aerosol is divided into hydrophobic and hydrophilic categories, for a total of 4 primary carbonaceous aerosol classes. Increased solubility of carbonaceous particles is generally considered to result from coating of the aerosol by soluble species such as sulfuric acid or sulfate.
Table 1. Classes of Reactive Terpenes

\begin{tabular}{cc}
\hline $\begin{array}{c}\text { Hydrocarbon } \\
\text { class }\end{array}$ & Composition \\
\hline I & $\alpha$-pinene, $\beta$-pinene, sabinene, $\Delta^{3}$-carene, terpenoid ketones \\
II & limonene \\
III & $\alpha$-terpinene, $\gamma$-terpinene, terpinolene \\
IV & myrcene, terpenoid alcohols, ocimene \\
V & sesquiterpenes \\
\hline
\end{tabular}

Accurate modeling of solubility would require knowledge of the rate at which ambient carbonaceous aerosols acquire a coating of hydrophilic material and also the hygroscopic behavior of the resulting particles, information that is not generally available. In the absence of such information, we adopt the estimate from the work of Cooke et al. [1999], that ambient conversion of carbonaceous aerosol from hydrophobic to hydrophilic occurs with an exponential decay lifetime of 1.15 days.

\subsubsection{Reactive Hydrocarbons}

[10] In order to represent the formation of SOA, the parent hydrocarbons that, upon atmospheric oxidation, lead to semivolatile products that form aerosol must be included as tracers in the model. Hydrocarbons with potential to form aerosols include monoterpenes and sesquiterpenes, which are biogenic in origin, as well as aromatics, long-chain carbonyls, and high-molecularweight alkenes, all of which are predominantly anthropogenic. Based on measured aerosol yield parameters [Wang et al., 1992; Hoffmann et al., 1997; Odum et al., 1997; Griffin et al., 1999a, 1999b], reac-tion rate constants with $\mathrm{O}_{3}, \mathrm{OH}$, and $\mathrm{NO}_{3}$ [Atkinson, 1994, 1997; Atkinson et al., 1995; Shu and Atkinson, 1995], and estimated global emissions [Piccot et al., 1992; Guenther et al., 1995; Griffin et al., 1999a], only hydrocarbons of biogenic origin are found to contribute significantly to global SOA formation. Table 1 lists the reactive hydrocarbons included as tracers, grouped into five categories according to the values of their experimentally measured aerosol yield parameters [Griffin et al., 1999b]. Because of lack of explicit experimental data, aerosol yield parameters of terpenoid ketones are assumed, because of their structural similarities, to be the same as those of sabinenes.

\subsection{Oxidation Products}

[11] While explicit molecular product identification of SOAs has shown that the number of products formed for each reaction can be large [Yu et al., 1999; Calogirou et al., 1999], Hoffmann et al. [1997] and Griffin et al. [1999b] have shown that a two-product model is sufficient for the purpose of representing experimentally observed SOA yields. Because the contributions of $\mathrm{O}_{3}$ and $\mathrm{OH}$ oxidation to SOA formation cannot generally be separated experimentally, oxidation by $\mathrm{O}_{3}$ and $\mathrm{OH}$ is considered together for the purpose of assigning aerosol products. Because of lack of experimental data on $\mathrm{NO}_{3}$ oxidation for all the terpenes, $\mathrm{NO}_{3}$ oxidation of $\beta$-pinene is used to represent $\mathrm{NO}_{3}$ oxidation of all hydrocarbons; in this case, a one-product model is sufficient [Griffin et al., 1999b].

[12] For each of the first four primary reactive hydrocarbons listed in Table 1, there are therefore three oxidation products, two for combined $\mathrm{O}_{3}$ and $\mathrm{OH}$ oxidation and one 
Table 2. Reaction Rate Constants for Hydrocarbon Oxidation $\left(\mathrm{cm}^{3}\right.$ molecule $\mathrm{s}^{-1}$ at $\left.298 \mathrm{~K}\right)$

\begin{tabular}{cccc}
\hline Hydrocarbon class & $k_{\mathrm{O} 3} \times 10^{18}$ & $k_{\mathrm{OH}} \times 10^{12}$ & $k_{\mathrm{NO} 3} \times 10^{12}$ \\
I & 56 & 84 & 7 \\
II & 200 & 171 & 12 \\
III & 7700 & 255 & 89 \\
IV & 423 & 199 & 15 \\
V & 11,650 & 245 & 27 \\
\hline
\end{tabular}

Sources: Atkinson et al. [1995], Shu and Atkinson [1995], and Atkinson [1997]. Rate constants for each hydrocarbon class are computed based on the arithmetic mean for the compounds listed in Table 1. The temperature dependence of reaction rate constants is given by

$$
\frac{k\left(T_{2}\right)}{k\left(T_{1}\right)}=\exp \left[-\frac{E}{R}\left(\frac{1}{T_{2}}-\frac{1}{T_{1}}\right)\right]
$$

where $T_{1}$ and $T_{2}$ are temperatures in $\mathrm{K}, E$ is the activation energy, and $R$ is the ideal gas constant. In the absence of explicit activation energy data for all the individual hydrocarbons, $E / R$ for the oxidation of $\alpha-$ pinene is used for all hydrocarbons: $732,-400$, and $-490 \mathrm{~K}$ for $\mathrm{O}_{3}$, $\mathrm{OH}$, and $\mathrm{NO}_{3}$ reactions, respectively [Atkinson, 1994].

for $\mathrm{NO}_{3}$ oxidation. In the case of sesquiterpenes, only two products are required (one for combined $\mathrm{O}_{3}$ and $\mathrm{OH}$ oxidation and one for $\mathrm{NO}_{3}$ oxidation) [Griffin et al., 1999a, 1999b]. All products are semivolatile and partition between the gas and aerosol phases; consequently, each product requires two tracers, one gas phase and one aerosol phase, for a total of 28 tracers in this group.

\subsection{Gas-Phase Chemistry and SOA Formulation}

[13] The chemical representation of SOA formation is based on the work of Hoffmann et al. [1997] and Griffin et al. [1999b]. A parent hydrocarbon, $\mathrm{HC}_{i}$, reacts in the gas phase with an oxidant, $\mathrm{OX}_{j}$, either $\mathrm{OH}, \mathrm{O}_{3}$, or $\mathrm{NO}_{3}$, to form a set of products, $\mathrm{G}_{i, j, k}$,

$$
\mathrm{HC}_{i}+\mathrm{OX}_{j} \rightarrow \alpha_{i, j, 1} \mathrm{G}_{i, j, 1}+\alpha_{i, j, 2} \mathrm{G}_{i, j, 2}+\cdots
$$

where $\alpha_{i, j, k}$ 's are mass-based stoichiometric coefficients. Monthly average three-dimensional $\mathrm{O}_{3}$ and $\mathrm{NO}_{3}$ fields are imported from the Harvard Chemical Transport Model (CTM) [Wang et al., 1998a, 1998b, 1998c]. Threedimensional fields of 5 day average $\mathrm{OH}$ radical concentrations are from C. Spivakovsky (personal communication, 1998). To account for the diel variation in $\mathrm{OH}$ and $\mathrm{O}_{3}$ concentrations, the instantaneous value is obtained by scaling with the cosine of the solar zenith angle. Daily $\mathrm{NO}_{3}$ concentrations are converted from monthly averages based on the number of dark hours during the day and are considered to be nonzero only during hours of no sunlight.

[14] Group-averaged reaction rate constants for $\mathrm{O}_{3}, \mathrm{OH}$, and $\mathrm{NO}_{3}$ oxidation are listed in Table 2. $\beta$-Caryophyllene and $\alpha$-humulene are used to represent all sesquiterpenes. Laboratory-derived values for the mass-based stoichiometric coefficients $\alpha_{i, j, k}$ are listed in Table 3. Again, for each reactive hydrocarbon group, the stoichiometric coefficient is taken as the arithmetic average of the values of the compounds in that group, as listed in Table 1. Properties of $\beta$ caryophyllene and $\alpha$-humulene are used to represent those of all sesquiterpenes.

[15] Once formed in the gas phase, the semivolatile reaction products $\mathrm{G}_{i, j, k}$ will partition between the gas and
Table 3. Mass-Based Stoichiometric Coefficients for Semivolatile

\begin{tabular}{|c|c|c|c|}
\hline \multirow[t]{2}{*}{ Hydrocarbon class } & \multicolumn{2}{|c|}{$\mathrm{O}_{3}+\mathrm{OH}$ oxidation } & \multirow{2}{*}{$\frac{\mathrm{NO}_{3} \text { oxidation }^{\mathrm{a}}}{\alpha_{i, 2,1}}$} \\
\hline & $\alpha_{i, 1,1}$ & $\alpha_{i, 1,2}$ & \\
\hline I & 0.067 & 0.354 & 1.0 \\
\hline II & 0.239 & 0.363 & 1.0 \\
\hline III & 0.069 & 0.201 & 1.0 \\
\hline IV & 0.067 & 0.135 & 1.0 \\
\hline $\mathrm{V}$ & 1.0 & $\ldots$ & 1.0 \\
\hline
\end{tabular}
Products from the Oxidation of Hydrocarbons

${ }^{\text {a }}$ Based on value of $\beta$-pinene for all compounds.

Sources: Griffin et al. [1999a, 1999b]. Stoichiometric coefficients for each hydrocarbon class are computed based on the arithmetic mean for the compounds listed in Table 1.

aerosol phases. We consider this partitioning to occur to the entire organic aerosol phase. Particles will generally contain some water, and water-soluble organic compounds do partition to the aqueous portion of the aerosol as well [Seinfeld et al., 2001]; however, we do not consider that process here. This should not lead to an appreciable error in estimating global SOA formation. The fraction of each product that partitions to the organic aerosol phase is governed by an equilibrium partition coefficient $K_{o m, i, j, k}$ [Pankow, 1994a, 1994b],

$$
[\mathrm{G}]_{i, j, k}=\frac{[\mathrm{A}]_{i, j, k}}{K_{o m, i, j, k} M_{o}}
$$

where $[\mathrm{G}]_{i, j, k}$ is the product concentration in the gas phase, $[\mathrm{A}]_{i, j, k}$ is the product concentration in the aerosol phase, and $M_{o}$ is the concentration of total organic aerosol, i.e.,

$$
M_{o}=[\mathrm{POA}]+\sum_{i, j, k}[\mathrm{~A}]_{i, j, k}
$$

where [POA] is the concentration of POA. The partition coefficients $K_{o m, i, j, k}$ corresponding to $\alpha_{i, j, k}$ in Table 3 are listed in Table 4.

[16] The partition coefficient can be expressed as follows [Pankow, 1994b]:

$$
K_{o m, i, j, k}=\frac{760 R T}{10^{6} M W_{o} \zeta_{i, j, k} p_{L, i, j, k}^{0}}
$$

where $\zeta_{i, j, k}$ is the activity coefficient of compound $\mathrm{G}_{i, j, k}$ in

\begin{tabular}{|c|c|c|c|}
\hline \multirow[t]{2}{*}{ Hydrocarbon } & \multicolumn{2}{|c|}{$\mathrm{O}_{3}+\mathrm{OH}$ oxidation } & \multirow{2}{*}{$\frac{\mathrm{NO}_{3} \text { oxidation }^{\mathrm{a}}}{K_{o m, i, 2,1}}$} \\
\hline & $K_{\text {om }, i, 1,1}$ & $K_{o m, i, 1,2}$ & \\
\hline I & 0.184 & 0.0043 & 0.0163 \\
\hline II & 0.055 & 0.0053 & 0.0163 \\
\hline III & 0.133 & 0.0035 & 0.0163 \\
\hline IV & 0.224 & 0.0082 & 0.0163 \\
\hline $\mathrm{V}$ & 0.0459 & $\ldots$ & 0.0163 \\
\hline
\end{tabular}
the organic aerosol phase, $M W_{o}$ is the molecular weight of the organic aerosol phase, and $p_{L, i, j, k}^{0}$ (torr) is the vapor

Table 4. Equilibrium Gas-Particle Partition Coefficients of Semivolatile Compounds $\left(\mathrm{m}^{3} \mu_{\mathrm{g}}^{-1}\right)$

${ }^{a}$ Based on value of $\beta$-pinene for all compounds.

Sources: Griffin et al. [1999a, 1999b]. Partition coefficients for each hydrocarbon class are computed based on the arithmetic mean for the compounds listed in Table 1. 
pressure of the compound at the temperature of interest (subcooled, if necessary). Using the Clausius-Clapeyron equation and assuming that $\zeta_{i, j, k}$ is constant, the temperature dependence of $K_{o m, i, j, k}$ is given by

$$
\frac{K_{o m, i, j, k}\left(T_{2}\right)}{K_{o m, i, j, k}\left(T_{1}\right)}=\frac{T_{2}}{T_{1}} \exp \left[\frac{\Delta H_{i, j, k}}{R}\left(\frac{1}{T_{2}}-\frac{1}{T_{1}}\right)\right]
$$

where $\Delta H_{i, j, k}$ is the enthalpy of vaporization. From the CRC Handbook of Chemistry and Physics [Lide, 2001], $\Delta H / R \approx 5 \times 10^{3} \mathrm{~K}$ for organic compounds, and this value is used for all compounds considered. This value translates into a range of values of $K_{o m, i, j, k}$ over about three orders of magnitude for tropospheric temperatures.

[17] As gas-phase reaction proceeds in each GCM grid cell, the semivolatile products repartition to establish equilibrium over a GCM time step. Using equation (1) and mass balance on each product, $M_{o}$ can be determined from

$$
\sum_{i, j, k}\left[\frac{K_{o m, i, j, k}\left(\alpha_{i, j, k} \Delta \mathrm{HC}_{i, j}+[\mathrm{A}]_{i, j, k}^{o}+[\mathrm{G}]_{i, j, k}^{o}\right)}{\left(1+K_{o m, i, j, k} M_{o}\right)}\right]+\frac{[\mathrm{POA}]}{M_{o}}=1
$$

where $\Delta \mathrm{HC}_{i, j}$ is the concentration of hydrocarbon $i$ that reacts with oxidant $j$, over the time step and $[\mathrm{A}]_{i, j, k}^{o}$ and $[\mathrm{G}]_{i, j, k}^{o}$ are the gas-phase and aerosol-phase concentrations at the beginning of the time step. The left-hand side of equation (5) is a monotonically decreasing function of $M_{o}$. If $[\mathrm{POA}]=0$, for example, and

$$
\sum_{i, j, k}\left[K_{o m, i, j, k}\left(\alpha_{i, j, k} \Delta \mathrm{HC}_{i, j}+[\mathrm{A}]_{i, j, k}^{o}+[\mathrm{G}]_{i, j, k}^{o}\right)\right]<1
$$

then $M_{o}=0$, and all products stay in the gas phase. Otherwise, $M_{o}$ is determined implicitly from equation (5), and $[\mathrm{A}]_{i, j, k}$ is determined by

$$
[\mathrm{A}]_{i, j, k}=\frac{K_{o m, i, j, k} M_{o}\left(\alpha_{i, j, k} \Delta \mathrm{HC}_{i, j}+[\mathrm{A}]_{i, j, k}^{o}+[\mathrm{G}]_{i, j, k}^{o}\right)}{\left(1+K_{o m, i, j, k} M_{o}\right)}
$$

Then, $[\mathrm{G}]_{i, j, k}$ is obtained from equation (1).

\subsection{Emissions}

[18] Anthropogenic emissions of carbonaceous aerosols are mainly from fossil fuel and biomass burning. Monthly emissions of $\mathrm{BC}$ and POAs are taken from the emission IPCC scenario A2 for the year 2000. Emissions are based on the work of Liousse et al. [1996] for biomass POA and BC and fossil fuel POA and the work of Penner et al. [1993] for fossil fuel BC. Globally averaged, $45 \%$ of $\mathrm{BC}$ and $55 \%$ of POA emitted are from fossil fuel burning. Annual emissions are shown in Figures 1 and 2. Of the total $\mathrm{BC}$ emitted, $80 \%$ is assumed to be hydrophobic, while $50 \%$ of the POA is assumed be to hydrophobic; the remaining portions are assumed to be hydrophilic [Cooke et al., 1999].

[19] While Liousse et al. [1996] provide the only inventory of carbonaceous aerosols from biomass burning, other emission inventories of carbonaceous aerosols from fossil fuel are also available, including those of the work of Cooke and Wilson [1996] (BC), Cooke et al. [1999] (BC and POA), and Bond [2000] (BC). The emission inventory we use is that designated as IPCC scenario A2 for the year 2000. The emission factors, which relate the mass of fuel burned to mass of aerosol emitted, vary by several orders of magnitude for different fuel types and burning efficiency and are highly uncertain. The BC inventory for fossil fuel used here from the work of Penner et al. [1993] is approximately a quarter of the emissions given by Cooke and Wilson [1996] and about half of those of Cooke et al. [1999] and Bond [2000] for North America. Primary emission of OC from fossil fuel is even more uncertain, as the $\mathrm{OC}$ inventory is inferred from the $\mathrm{BC}$ inventory. Also, the inventory used here was developed using data from the Food and Agriculture Organization for 1980 [Liousse et al., 1996], and increases in emissions would have occurred since then.

[20] Global monthly emission inventories of total monoterpenes and other reactive VOCs (ORVOCs) from biogenics are obtained from the Global Emissions Inventory Activity (GEIA) and are based on the work of Guenther et al. [1995]. Global annual emission distributions are shown in Figures 3 and 4. By determining the predominant plant species associated with the ecosystem types and the specific monoterpene and ORVOC emissions from these plant species, the contributions of individual compounds can be estimated. The percent contribution of each compound to total monoterpene and ORVOC emissions is reported by Griffin et al. [1999a] and is assumed to be constant geographically. Emissions of monoterpenes and ORVOCs vary diurnally as emission rates change with the light and leaf temperature [Guenther et al., 1995]. For simplicity, to obtain the instantaneous emission rate of biogenic hydrocarbons, monthly averages are scaled by the solar zenith angle. A summary of emissions used in the current work is given in Table 5 .

\subsection{GISS GCM II-Prime}

[21] Tracer processes are handled online in the GISS GCM II-prime [Hansen et al., 1983; Rind and Lerner, 1996]. Recent improvements relevant to the GISS GCM II-prime are discussed by Rind and Lerner [1996]. The resolution is $4^{\circ}$ latitude by $5^{\circ}$ longitude, with nine $\sigma$ layers in the vertical direction, from the surface to 10 mbar. The vertical layers are centered approximately at 959, 894, 786, 634, 468, 321, 201, 103, and 27 mbar. The model surface layer is 50 mbar thick. The top one or two layers are situated in the stratosphere. The boundary layer parameterization uses a new scheme that incorporates a finite modified Ekman layer [Hartke and Rind, 1997]. The dynamic time step for tracer processes is 1 hour. The GCM utilizes a fourth-order scheme for momentum advection. Tracers, heat, and moisture are advected each time step by the model winds using the quadratic upstream scheme, which is mathematically equivalent to the second-order moment method of Prather [1986].

\subsubsection{Wet Deposition}

[22] Wet deposition of dissolved tracers generally follows the GCM treatment of liquid water, which is described by Del Genio and Yao [1993] and Del Genio et al. [1996]. The GCM distinguishes between large-scale (stratiform) and convective clouds. During in-cloud scavenging, gas-phase 


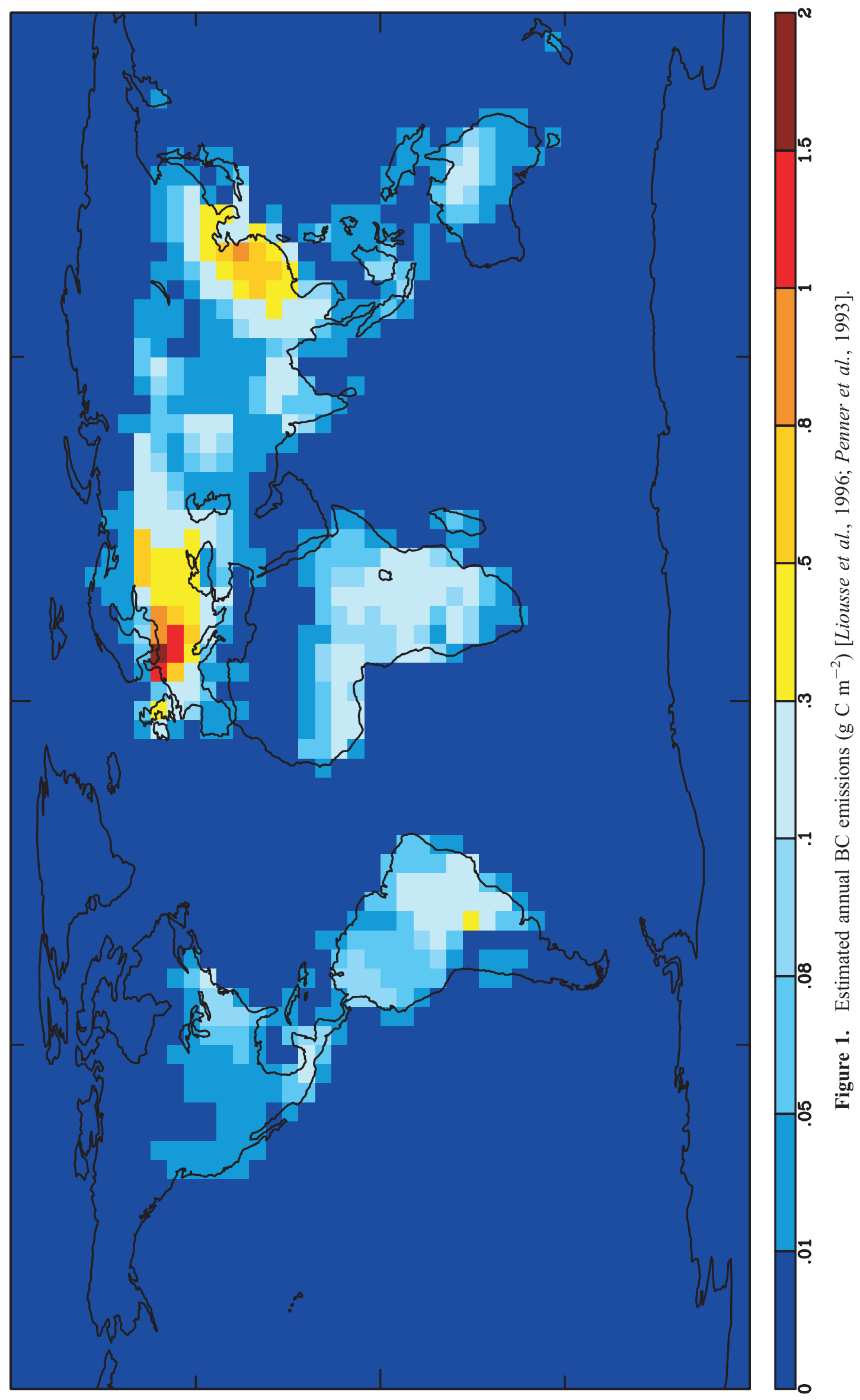


AAC $14-6$ CHUNG AND SEINFELD: DISTRIBUTION AND CLIMATE FORCING

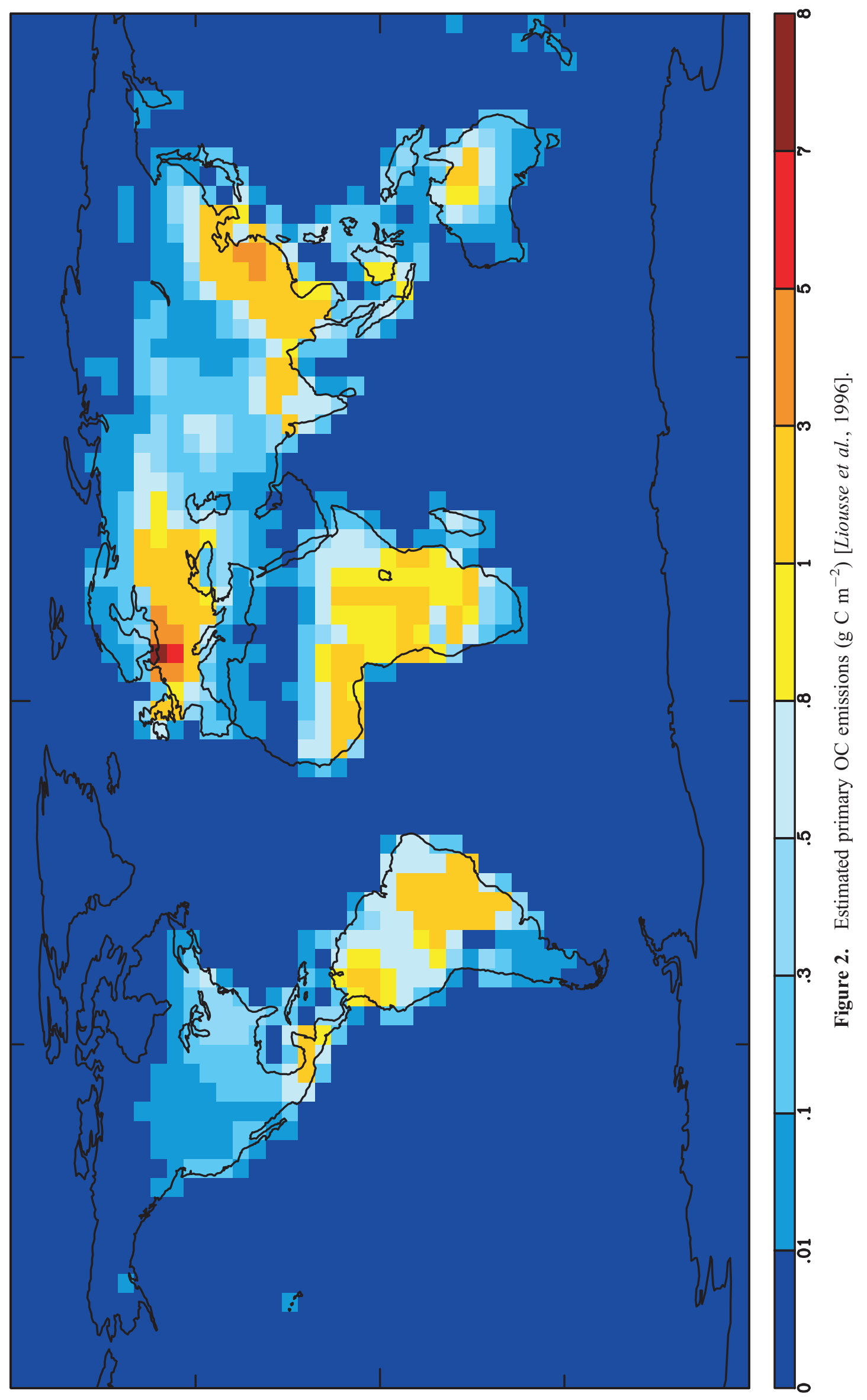




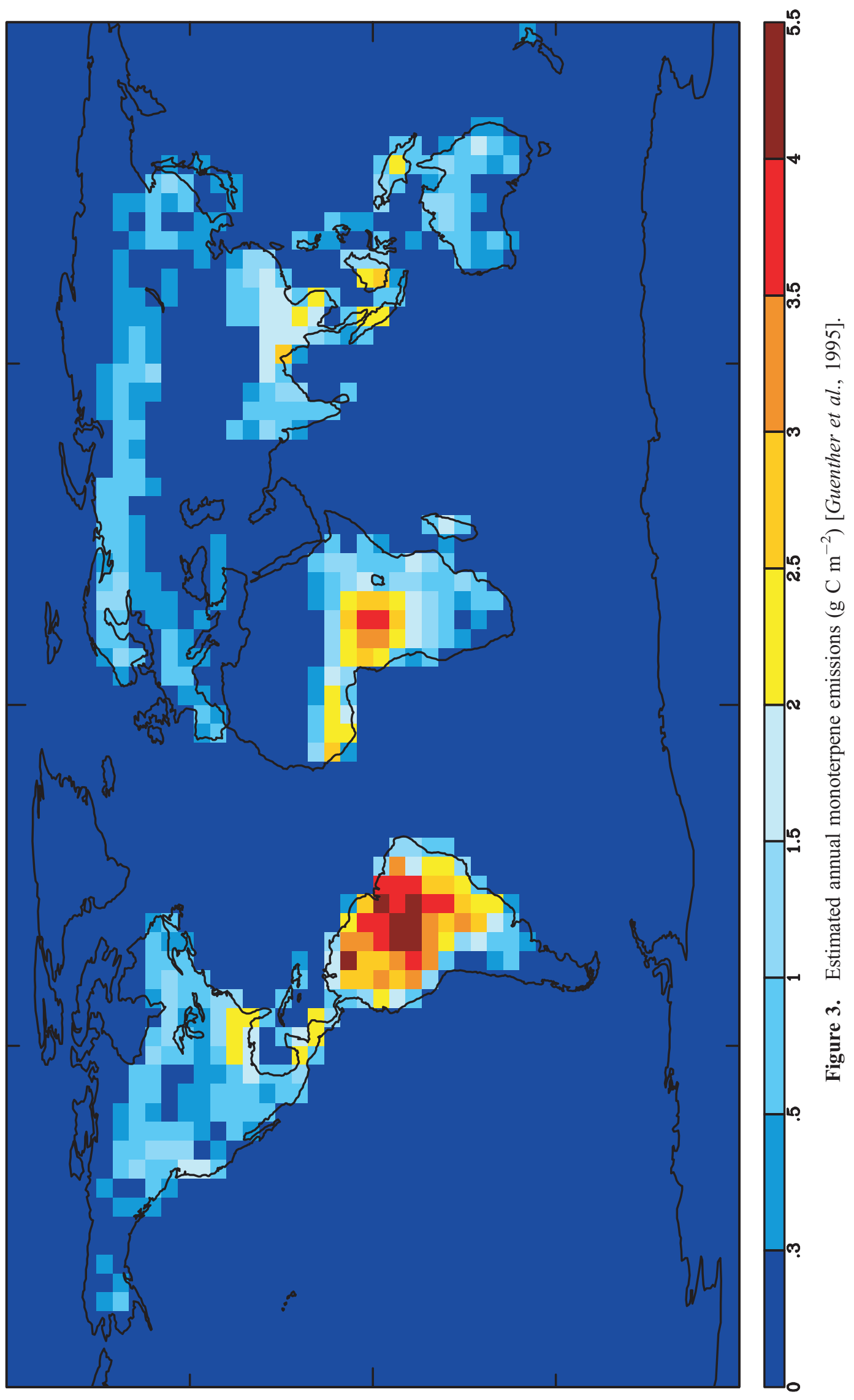




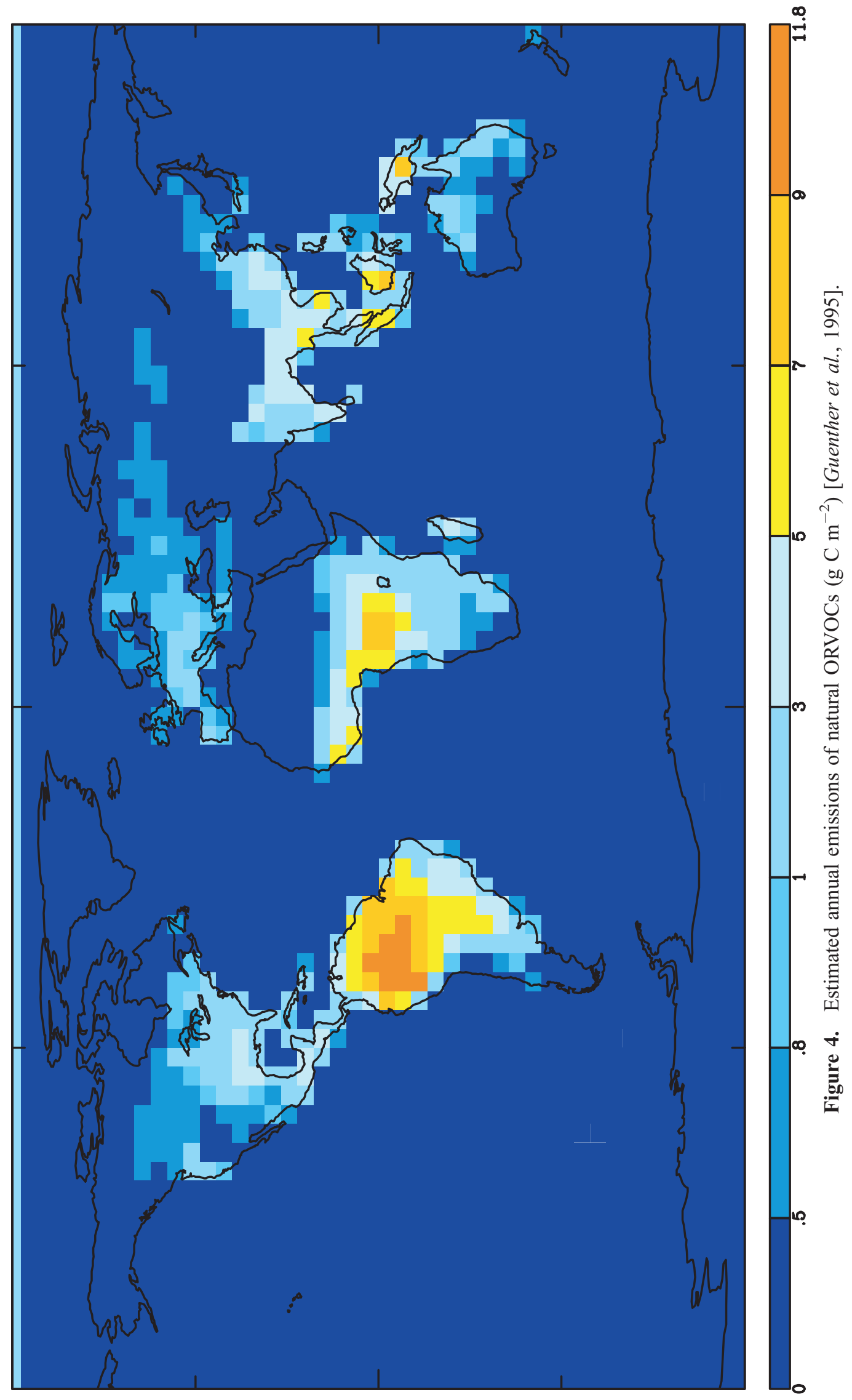


Table 5. Estimated Annual Emissions of SOA Precursors, POA, and $\mathrm{BC}$

\begin{tabular}{|c|c|c|c|}
\hline Tracer & Compound & \multicolumn{2}{|c|}{$\begin{array}{l}\text { Emission } \\
\left(\mathrm{Tg} \mathrm{yr}^{-1}\right)\end{array}$} \\
\hline \multirow[t]{5}{*}{$\mathrm{I}^{\mathrm{a}}$} & & & 109 \\
\hline & $\alpha$-Pinene & 50 & \\
\hline & $\beta$-Pinene & 33 & \\
\hline & Sabinene and terpenoid ketones & 20 & \\
\hline & ${ }^{3} \Delta$-Carene & 6 & \\
\hline $\mathrm{II}^{\mathrm{a}}$ & Limonene & & 33 \\
\hline \multirow[t]{3}{*}{$\mathrm{III}^{\mathrm{a}}$} & & & 4.3 \\
\hline & $\alpha$ - and $\gamma$-Terpinene & 1.4 & \\
\hline & Terpinolene & 2.9 & \\
\hline \multirow[t]{4}{*}{$\mathrm{IV}^{\mathrm{a}}$} & & & 40 \\
\hline & Myrcene & 7 & \\
\hline & Terpenoid alcohols & 30 & \\
\hline & Ocimene & 3 & \\
\hline $\mathrm{V}^{\mathrm{a}}$ & Sesquiterpenes & & 15 \\
\hline $\mathrm{POA}^{\mathrm{b}}$ & & & 81 \\
\hline $\mathrm{BC}^{\mathrm{b}, \mathrm{c}}$ & & & 12 \\
\hline
\end{tabular}

species dissolve into cloud water according to their Henry's law coefficients (Table 6), and aerosol-phase species dissolve according to their scavenging efficiencies [Koch et al., 1999]. When data are available, Henry's law coefficients for the SOA precursor hydrocarbons represent averages for species in that group. Since the Henry's law coefficients for the parent hydrocarbons are relatively small, wet scavenging of these species proves to be insignificant. Indeed, the dominant sink for the reactive hydrocarbons is oxidation by $\mathrm{O}_{3}, \mathrm{OH}$, and $\mathrm{NO}_{3}$. Biogenic hydrocarbon oxidation products are expected to consist of multifunctional oxygenated compounds with a large fraction being carboxylic acids and dicarboxylic acids [Saxena and Hildemann, 1996; Calogirou et al., 1999]. From the compilation of Henry's law coefficients by Sander [1999], $H \approx 10^{3}-10^{4} \mathrm{M} \mathrm{atm}^{-1}$ for carboxylic acids, and $H \approx 10^{6}-10^{8} \mathrm{M} \mathrm{atm}^{-1}$ for dicarboxylic acids; therefore, $10^{5} \mathrm{M} \mathrm{atm}^{-1}$ is a reasonable value to represent those of the gas-phase products. By similar reasoning, $\Delta H_{A} / R=-12 \mathrm{~K}$ is used to represent the temperature dependence of $H$ :

$$
\frac{d \ln H}{d T}=\frac{\Delta H_{A}}{R T^{2}}
$$

where $\Delta H_{A}$ is the heat of dissolution. Temperature dependence of Henry's law coefficients need not be considered for the reactants.

[23] Hydrophobic aerosols are assumed to be insoluble; hydrophilic aerosols are assumed to be infinitely soluble. For SOAs, $80 \%$ are assumed to dissolve into clouds, consistent with findings of Limbeck and Puxbaum [2000].

[24] Transport of dissolved chemical tracers follows the convective air mass transport, and scavenging is applied only to species within or below the cloud updraft. Moist convection includes a variable mass flux scheme determined by the amount of instability relative to the wet adiabat, two plumes, one entraining and one nonentraining, as well as compensating subsidence and downdrafts [Del Genio and Yao, 1993]. All liquid water associated with convective clouds either precipitates, evaporates, or detraines within the 1 hour GCM time step, and the dissolved chemical tracers are either deposited (in case of precipitation) or returned to the air (in case of evaporation or detrainment) in corresponding proportions. All water condensed above a certain level (typically $550 \mathrm{mbar}$ ) is detrained into cirrus anvils and added to the large-scale cloud liquid water content, which is carried as a prognostic variable in the GCM. For large-scale, in-cloud scavenging, tracers are redissolved into cloud water (using Henry's law coefficients or scavenging efficiencies) and scavenged according to a first-order rate loss parameterization that depends on the rate of conversion of cloud into rainwater. Below both types of clouds, aerosols and soluble gases are scavenged according to a first-order parameterization that depends on the amount of precipitation [Koch et al., 1999]. Dissolved tracer is returned to the atmosphere if precipitation from either type of cloud evaporates.

\subsubsection{Dry Deposition}

[25] Dry deposition of all gas-phase species is based on a resistance-in-series parameterization [Wesely and Hicks, 1977]. Aerodynamic resistances are computed as a function of GCM surface momentum and heat fluxes. Surface resistances are scaled to the resistance of $\mathrm{SO}_{2}$, which is parameterized as a function of local surface type, temperature, and insolation [Wesely, 1989]. The scaling uses the Henry's law coefficients in Table 6, ratio of molecular diffusivities of the species in air to that of water vapor (estimated using the ratios of molecular weights), and a surface reactivity factor $f_{0}$. All tracers are assumed to be nonreactive at the surface; therefore, $f_{0}=0$. For all aerosols, the deposition velocity of $0.1 \mathrm{~cm} \mathrm{~s}^{-1}$ is used [Liousse et al., 1996].

\section{Simulated Global Distributions of BC, POA, and SOA}

[26] This section presents simulated aerosol concentration fields. We also present comparisons to observations and previous work. The GCM predictions are averaged over a 3 year period after 11 months of initial spin-up.

\subsection{Global Distributions and Lifetimes}

[27] Figure 5 shows the predicted annual global distributions of BC, POA, and SOA. Distributions of BC and POA exhibit maxima near source regions over the continents, especially in Europe and eastern Asia. The transport of biomass burning aerosols from tropical Africa and South

Table 6. Henry's Law Coefficients for Gas-Phase SOA Parent Hydrocarbons and Oxidation Products

\begin{tabular}{lcc}
\hline \multicolumn{1}{c}{ Tracer } & $H\left(\mathrm{M} \mathrm{atm}^{-1}\right)$ at $298 \mathrm{~K}$ & \multicolumn{1}{c}{ Reference } \\
\hline I & 0.023 & Falk et al. $[1990]$, Li et al. \\
& & [1998], Sander [1999] \\
II & 0.07 & Falk et al. [1990] \\
III & 0.067 & Li et al. $[1998]$ \\
IV & 54 & Li et al. $[1998]$ \\
$V^{\text {a }}$ & 0.049 & Sander [1999] \\
Oxidation products $^{\text {b }}$ & $10^{5}$ & Sander [1999] \\
\hline
\end{tabular}

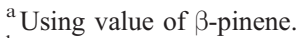

${ }^{\mathrm{b}}$ See text for explanation. 
AAC $14-10$ CHUNG AND SEINFELD: DISTRIBUTION AND CLIMATE FORCING
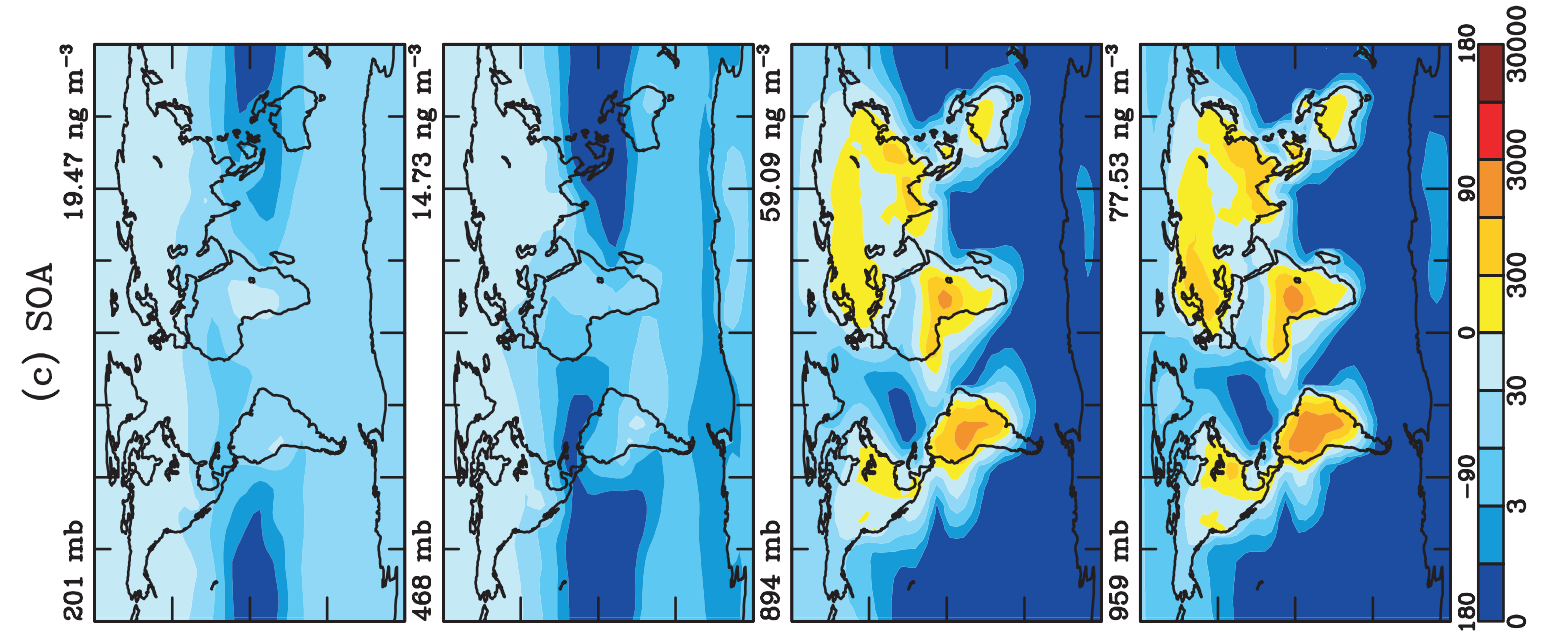

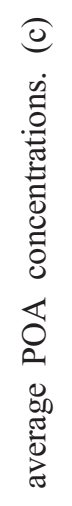

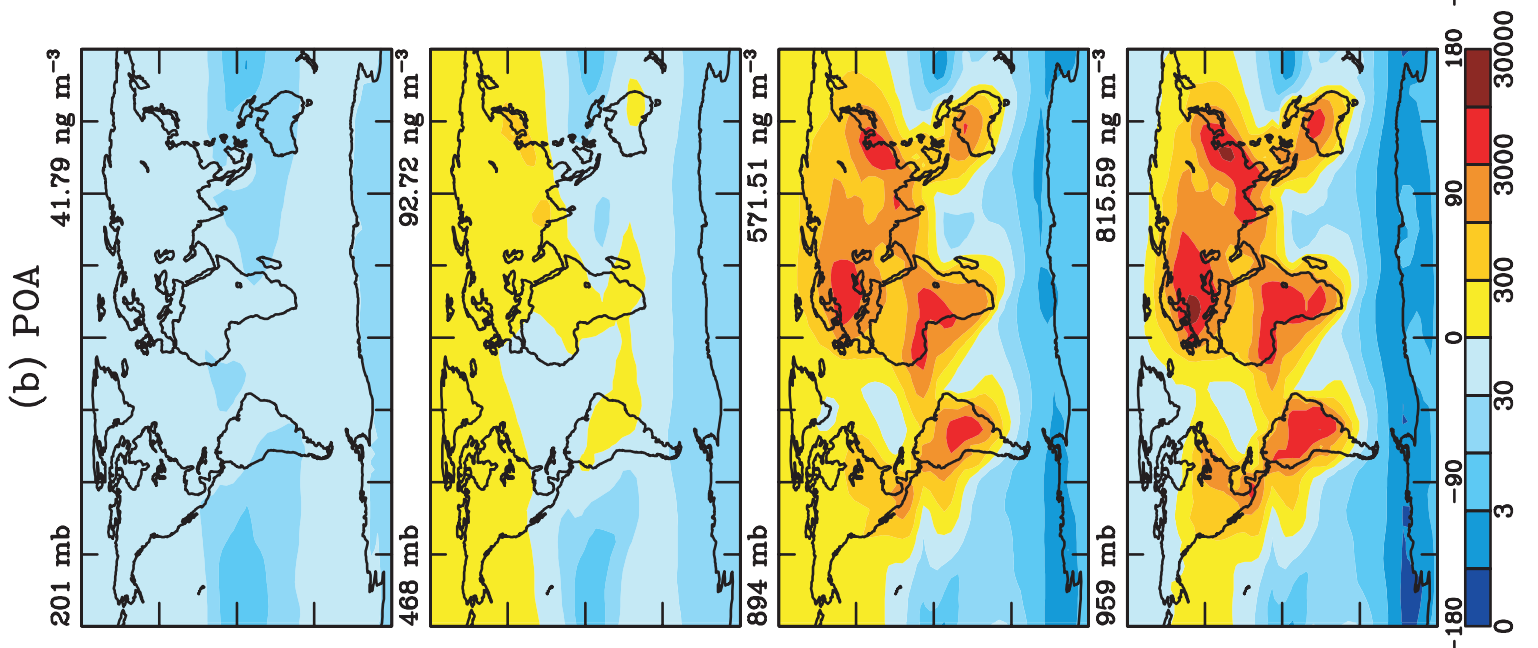

蛋

惫

$\hat{e}_{n}$.

$\stackrel{0}{0} \Xi$

苛

ठั.

บ :

윰
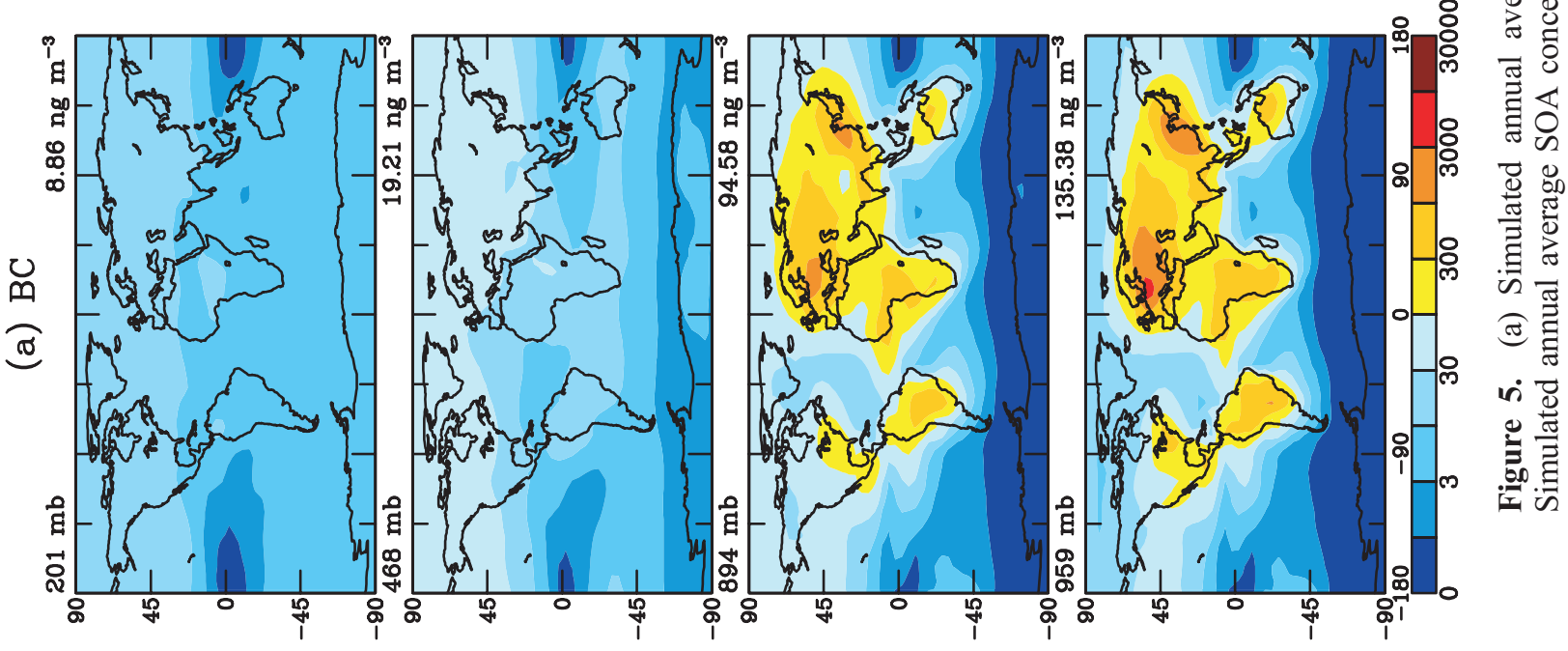


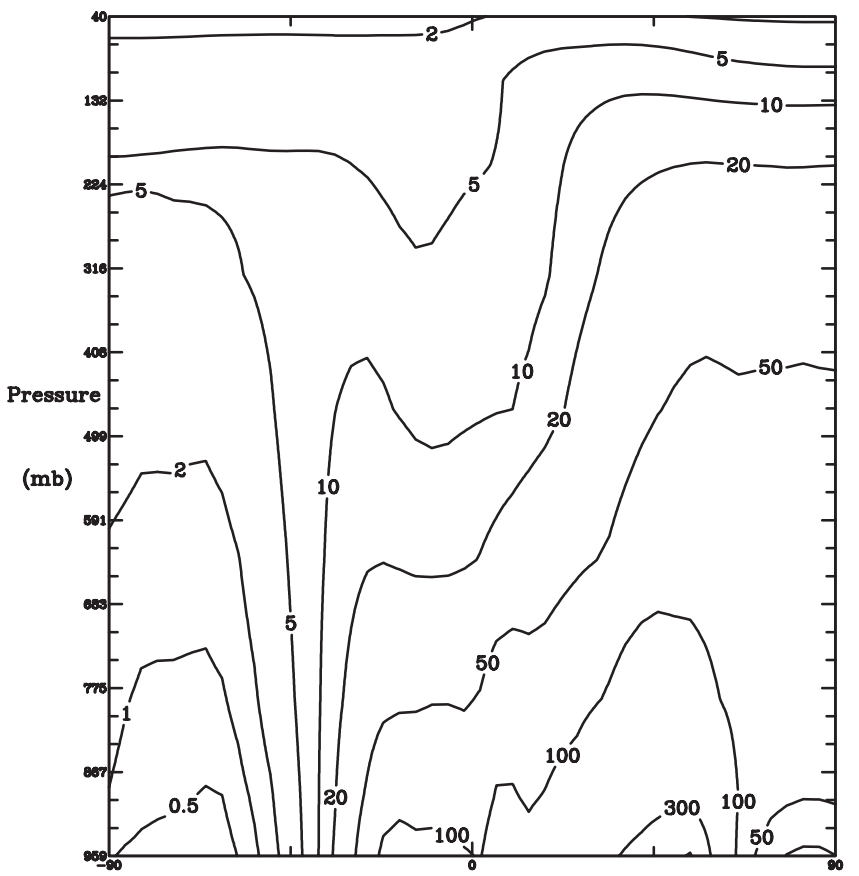

Latitude

Figure 6. Predicted zonal annual average global BC distribution $\left(\mathrm{ng} \mathrm{m}^{-3}\right)$.

America to the Atlantic and Pacific Oceans, respectively, is also evident. On average, the $\mathrm{BC}$ burden is predicted to be about 10 times larger in the Northern Hemisphere $(\mathrm{NH})$ than in the Southern Hemisphere ( $\mathrm{SH}$ ) because of the predominance of fossil fuel sources. For the same reason, NH abundance of POA is also about 10 times as large as that in the SH. SH POA is dominated by biomass burning sources in South America and Africa, whereas NH POA is dominated by fossil fuel emissions in the US, Europe, and eastern Asia, as well as biomass burning in the former USSR. Surface concentrations of SOA follow similar trends to those of POA, since regions of high biogenic emissions tend to overlap with regions of high concentrations of POA, which provide the absorptive medium into which the semivolatile products can condense.

[28] Figures 6-8 show the predicted zonal annual average global distribution of BC, POA, and SOA. For both BC and POA the surface concentration is predicted to be highest at northern midlatitudes, indicating the importance of fossil fuel sources. High concentrations in the tropics reflect the significance of biomass burning. Concentrations drop rapidly with height, as distance from the sources increases. The low concentration in the tropical upper troposphere is evidence of removal by convective scavenging. Similar to $\mathrm{BC}$ and POA, SOA surface concentrations are predicted to be highest in the tropics and northern midlatitudes. Unlike the primary aerosols, however, SOA concentration is predicted to exhibit a secondary peak around 400 mbar in extreme northern latitudes. The quantities at higher altitudes result from the transport of gas-phase oxidation products to the upper troposphere, where colder temperatures favor condensation of the semivolatile gases into the aerosol phase. The peak is not as strong in the SH because POA

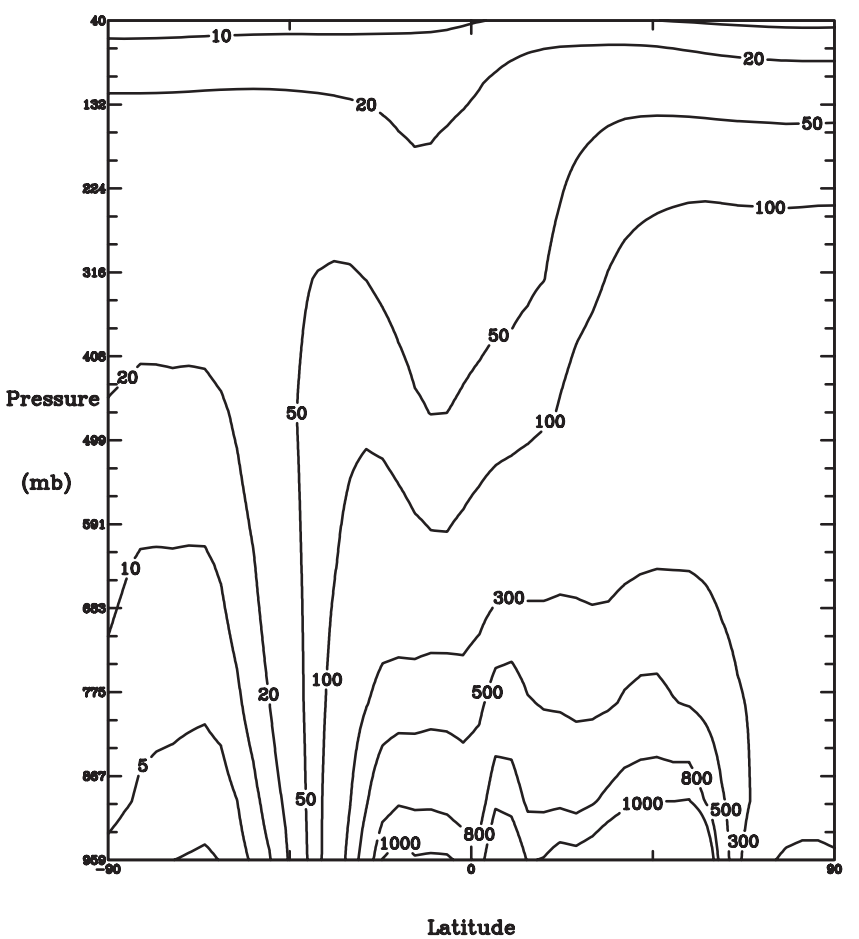

Figure 7. Predicted zonal annual average global POA distribution $\left(\mathrm{ng} \mathrm{m}^{-3}\right)$.

concentrations are lower in the $\mathrm{SH}$, resulting in less absorptive aerosol into which the semivolatile gas condense. Even for products with small partition coefficients, $K_{o m}$, at $298 \mathrm{~K}$ (see Table 4 ), $K_{\text {om }}$ increases by three orders of magnitude (section 2.3) from the temperatures of the surface to those of

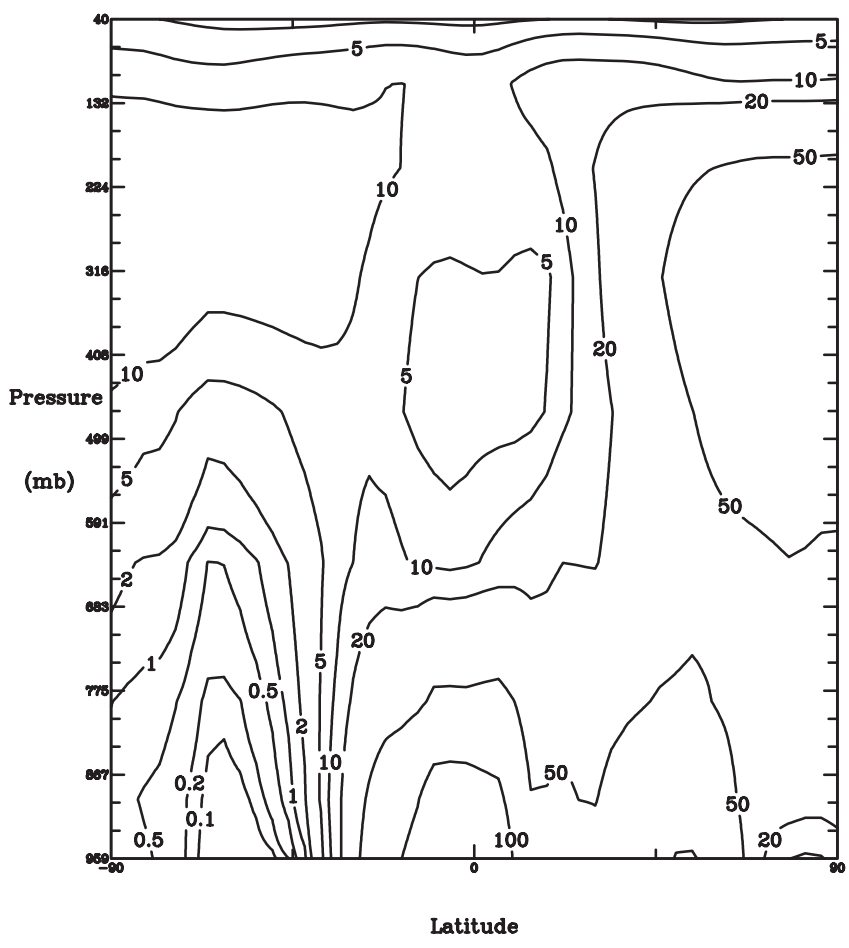

Figure 8. Predicted zonal annual average global SOA distribution $\left(\mathrm{ng} \mathrm{m}^{-3}\right)$. 


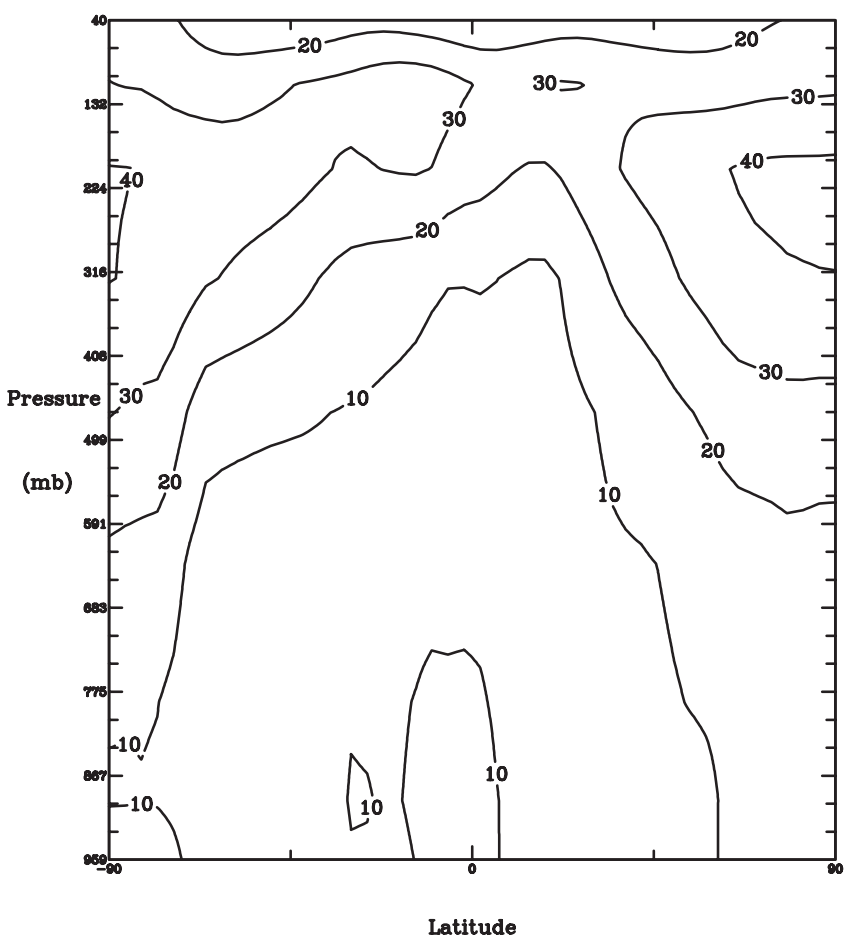

Figure 9. Predicted zonal annual average of the SOA global percentage of total organic aerosol (SOA + POA).

the upper troposphere, and eventually gas-phase products condense as temperature decreases sufficiently. Figure 9 shows the percentage of organic aerosol that is SOA. Near the surface, OC is dominated by POA, but SOA is predicted to contribute approximately one-half of the organic aerosol in the upper troposphere. Again, SOA contribution is predicted to be highest near the polar regions of the upper troposphere. Such predictions of secondary maxima of SOA levels in the cold regions of the upper troposphere have not been verified observationally, although the physics leading to this phenomenon is quite evident.

[29] Simulated global burdens and estimated lifetimes of BC, POA, and SOA are summarized in Table 7. In all cases, the dominant sink is wet deposition, estimated to contribute $66 \%, 69 \%$, and $77 \%$ to the total removal of $\mathrm{BC}$, POA, and SOA, respectively. The lifetime of $\mathrm{BC}$ is predicted to be longer than that of POA because a higher percentage of $\mathrm{BC}$ is assumed to be hydrophobic, which limits wet scavenging. As noted in section 2.5.1, hydrophobic aerosols are treated as completely insoluble; therefore, they are not removed by in-cloud wet scavenging (they are removed by below-cloud scavenging, dry deposition, and conversion to hydrophilic aerosols). The lifetime of SOA is predicted to be larger than that of POA because only $80 \%$ of SOA is considered to be soluble. As seen from Table 7, the lifetime of hydrophilic BC is larger than that for hydrophilic POA even though the dry and wet scavenging schemes are the same for both aerosols; the reason is that a higher percentage of hydrophilic $\mathrm{BC}$ is converted to the hydrophilic state in regions away from the source and in regions of less precipitation.

[30] The estimated global production of SOA is $11.2 \mathrm{Tg}$ $\mathrm{yr}^{-1}$. Table 8 lists the contribution of each class of reactive
Table 7. Predicted Global Burdens and Lifetimes $(\tau)$

\begin{tabular}{lccc}
\hline Aerosol & & Burden $(\mathrm{Tg})$ & $\tau$ (days) \\
\hline BC & & 0.22 & 6.4 \\
& hydrophobic & 0.03 & 1.0 \\
& hydrophilic & 0.19 & 6.4 \\
POA & & 1.2 & 5.3 \\
& hydrophobic & 0.1 & 1.0 \\
& hydrophilic & 1.1 & 5.2 \\
SOA & & 0.19 & 6.2 \\
\hline
\end{tabular}

hydrocarbons to the global SOA production. Tables 5 and 8 indicate that emission rates are not correlated with SOA production. For example, while sesquiterpenes (class V) contribute only about $8 \%$ to the total annual emissions of biogenic hydrocarbons, this class contributes to $22 \%$ of the total SOA. This result emphasizes the need for compoundspecific biogenic emission inventories and aerosol yield parameters. Table 8 also indicates that the contribution from group III ( $\alpha$ - and $\gamma$-terpinene and terpinolene) is insignificant.

[31] On a global average, $\mathrm{NO}_{3}$ is predicted to be responsible for only about $2 \%$ of the chemical sink of the parent hydrocarbons, while $\mathrm{NO}_{3}$ oxidation products are estimated to contribute about $9 \%$ to total SOA. The small contribution from $\mathrm{NO}_{3}$ is a result of the fact that biogenic hydrocarbons are emitted during daylight hours and are rapidly oxidized by $\mathrm{O}_{3}$ and $\mathrm{OH}$. The error introduced by assuming that all $\mathrm{NO}_{3}$ oxidation products behave the similarly to those of $\beta$-pinene oxidation by $\mathrm{NO}_{3}$ is, consequently, negligible.

\subsection{Comparison With Observations}

[32] In this section we compare the predicted fields of carbonaceous aerosols with observations. Observational data for carbonaceous aerosols are limited, especially for organic aerosols. Most available data were taken over a short period of time at specific locations, making comparison to monthly averages in a GCM grid cell difficult as a basis from which to draw wide-ranging conclusions about the adequacy of the global simulation. To convert to $\mathrm{OC}$ mass, which is measured experimentally, we assume that the ratio of organic aerosol mass to OC mass is 1.3 [Liousse et al., 1996]. The assumption of a single value for this conversion factor is, of course, a source of uncertainty.

[33] Table 9 compares the simulation results to the Interagency Monitoring of Protected Visual Environments (IMPROVE) database [Malm et al., 2000]. The IMPROVE network consists of aerosol and optical measurements at approximately 140 rural sites in the United States. Twentyfour hour aerosol samples were taken twice a week (on Wednesdays and Saturdays). The observation data are

Table 8. Parent Hydrocarbon Contributions to Global Average SOA

\begin{tabular}{cc}
\hline Hydrocarbon class & \% Contribution to SOA \\
\hline I & 45 \\
II & 21 \\
III & 1 \\
IV & 11 \\
V & 22 \\
\hline
\end{tabular}


Table 9. Comparison of Simulated and Observed Aerosol Concentrations from the IMPROVE Database

\begin{tabular}{|c|c|c|c|c|c|c|c|}
\hline \multirow[t]{2}{*}{$\begin{array}{ll}\text { Location } & \end{array}$} & \multirow[t]{2}{*}{ Longitude } & \multirow[t]{2}{*}{ Latitude } & \multirow[t]{2}{*}{ Elevation (m) } & \multicolumn{2}{|c|}{$[\mathrm{BC}]\left(\mathrm{ng} \mathrm{m}^{-3}\right)$} & \multicolumn{2}{|c|}{$[\mathrm{OC}]\left(\mathrm{ng} \mathrm{C} \mathrm{m}^{-3}\right)$} \\
\hline & & & & Obs & Sim & Obs & Sim \\
\hline Acadia National Park, Maine & -68.26 & 44.37 & 129 & 240 & 169 & 1470 & 706 \\
\hline Badlands National Park, South Dakota & -101.94 & 43.74 & 736 & 140 & 73 & 1130 & 301 \\
\hline Bandelier National Monument, New Mexico & -106.27 & 35.78 & 1987 & 170 & 53 & 1140 & 249 \\
\hline Big Bend National Park, Texas & -103.18 & 29.30 & 1075 & 180 & 103 & 1450 & 519 \\
\hline Boundary Waters Canoe Area, Minnesota & -91.50 & 47.95 & 524 & 190 & 106 & 1470 & 468 \\
\hline Bryce Canyon National Park, Utah & -112.17 & 37.42 & 2477 & 140 & 30 & 990 & 120 \\
\hline Bridger Wilderness, Wyoming & -109.76 & 42.98 & 2627 & 110 & 34 & 940 & 133 \\
\hline Brigantine National Wildlife Refuge, New Jersey & -74.45 & 39.47 & 9 & 510 & 179 & 2390 & 692 \\
\hline Canyonlands National Park, Utah & -109.82 & 38.46 & 1799 & 150 & 46 & 820 & 200 \\
\hline Chassahowitzka National Wildlife, Florida & -82.55 & 28.75 & 2 & 580 & 218 & 2780 & 989 \\
\hline Chiricahua National Monument, Arizona & -109.39 & 32.01 & 1570 & 130 & 53 & 920 & 249 \\
\hline Crater Lake National Park, Oregon & -122.14 & 42.90 & 1963 & 190 & 52 & 1100 & 178 \\
\hline Denali National Park, Alaska & -148.97 & 63.72 & 658 & 100 & 30 & 670 & 102 \\
\hline Dolly Sods/Otter Creek Wilderness, West Virginia & -79.43 & 39.11 & 1158 & 400 & 179 & 2440 & 762 \\
\hline Glacier National Park, Montana & -114.00 & 48.51 & 979 & 360 & 53 & 2520 & 229 \\
\hline Great Basin National Park, Nevada & -114.22 & 39.01 & 2068 & 160 & 49 & 1030 & 191 \\
\hline Hopi Point (Grand Canyon), Arizona & -112.15 & 36.07 & 2164 & 160 & 49 & 730 & 191 \\
\hline Great Sand Dunes National Monument, Colorado & -105.52 & 37.72 & 2504 & 110 & 30 & 920 & 131 \\
\hline Great Smokey Mountains National Park, Tennessee & -83.94 & 35.63 & 815 & 450 & 162 & 2910 & 753 \\
\hline Guadalupe Mountains National Park, Texas & -104.81 & 31.83 & 1674 & 150 & 70 & 1010 & 369 \\
\hline Jarbidge Wilderness, Nevada & -115.43 & 41.89 & 1882 & 120 & 51 & 1070 & 191 \\
\hline Lassen Volcanic National Park, California & -121.58 & 40.54 & 1755 & 170 & 52 & 1380 & 178 \\
\hline Lone Peak Wilderness, Utah & -111.71 & 40.44 & 1768 & 330 & 49 & 1560 & 190 \\
\hline Lye Brook Wilderness, Vermont & -73.12 & 43.15 & 1010 & 260 & 177 & 1520 & 725 \\
\hline Mammoth Cave National Park, Kentucky & -86.15 & 37.13 & 248 & 500 & 325 & 2830 & 1455 \\
\hline Mesa Verde National Park, Colorado & -108.49 & 37.20 & 2177 & 160 & 46 & 910 & 200 \\
\hline Moosehorn National Wildlife Refuge, Maine & -67.26 & 45.12 & 76 & 250 & 169 & 1700 & 706 \\
\hline Mount Rainier National Park, Washington & -122.12 & 46.76 & 427 & 310 & 91 & 2050 & 375 \\
\hline Mount Zirkel Wilderness, Colorado & -106.73 & 40.47 & 3243 & 110 & 34 & 820 & 133 \\
\hline Okefenokee National Wildlife Refuge, Georgia & -82.13 & 30.74 & 49 & 500 & 218 & 2990 & 989 \\
\hline Petrified Forest National Park, Arizona & -109.77 & 35.08 & 1767 & 220 & 53 & 1070 & 249 \\
\hline Pinnacles National Monument, California & -121.16 & 36.49 & 317 & 340 & 160 & 1780 & 609 \\
\hline Point Reyes National Seashore, California & -122.90 & 38.12 & 38 & 140 & 160 & 1230 & 609 \\
\hline Redwood National Park, California & -124.08 & 41.56 & 245 & 80 & 110 & 980 & 472 \\
\hline Cape Romain National Wildlife Refuge, South Carolina & -76.99 & 32.94 & 3 & 440 & 192 & 2800 & 781 \\
\hline Rocky Mountain National Park, Colorado & -105.55 & 40.28 & 2400 & 150 & 47 & 1020 & 191 \\
\hline San Gorgonio Wilderness, California & -116.90 & 34.18 & 1712 & 370 & 51 & 2040 & 193 \\
\hline Sequoia National Park, California & -118.82 & 36.50 & 549 & 510 & 71 & 3280 & 274 \\
\hline Shenandoah National Park, Virginia & -78.43 & 38.52 & 1098 & 370 & 179 & 2200 & 762 \\
\hline Shining Rock Wilderness, North Carolina & -82.77 & 35.39 & 1621 & 270 & 66 & 1790 & 293 \\
\hline Sipsy Wilderness, Alabama & -87.31 & 34.34 & 279 & 590 & 277 & 3400 & 1298 \\
\hline Snoqualamie Pass, Washington & -121.43 & 47.42 & 1160 & 300 & 59 & 1450 & 249 \\
\hline Three Sisters, Oregon & -122.04 & 44.29 & 885 & 180 & 59 & 1490 & 249 \\
\hline Tonto National Monument, Arizona & -111.11 & 33.65 & 786 & 220 & 89 & 1280 & 371 \\
\hline Upper Buffalo Wilderness, Arkansas & -93.20 & 35.83 & 723 & 340 & 156 & 2350 & 750 \\
\hline Weminuche Wilderness, Colorado & -107.80 & 37.66 & 2765 & 160 & 30 & 760 & 131 \\
\hline Yellowstone National Park, Wyoming & -110.40 & 44.57 & 2425 & 120 & 49 & 1320 & 210 \\
\hline Yosemite National Park, California & -119.70 & 37.71 & 1615 & 240 & 48 & 2280 & 180 \\
\hline
\end{tabular}

$\mathrm{NP}=$ National Park; NWR $=$ National Wildlife Refuge.

Reference: Malm et al. [2000].

averaged over 3 years from March 1996 to February 1999. Related scatterplots are also shown in Figures 10 and 11. The comparison indicates that the GCM simulation consistently underpredicts both $\mathrm{BC}$ and $\mathrm{OC}$ concentrations at this set of locations by about a factor of 3-4. The underprediction is probably the result of averaging over large grid cells as well as uncertainties in the emission inventory itself. As discussed in section 2.4 earlier, the BC emissions from fossil fuel used here are less than those used by Cooke and Wilson [1996], Cooke et al. [1999], and Bond [2000].

[34] Tables 10-15 show comparison of $\mathrm{BC}$ and $\mathrm{OC}$ concentrations at various rural, remote, and marine sites, with the corresponding scatterplots in Figures 10 and 11. Overall, both $\mathrm{OC}$ and $\mathrm{BC}$ concentrations are underpredicted by about a factor of 2 , except at remote sites, for which there are too few data points to draw definitive conclusions. The consistent underestimation suggests that either emissions are too low or wet scavenging is too high.

\subsubsection{Seasonal Variations of $B C$}

[35] An analysis that is perhaps more relevant to judging the accuracy of the GCM simulation that uses averaged climatology over large grid cells is the comparison with long-term observations that smooth out day-to-day variations.

[36] Figure 12 shows the observed and simulated BC concentrations at six different sites in the $\mathrm{NH}$. Figure 12a shows the comparison in Barrow, Alaska $\left(71.2^{\circ} \mathrm{N}, 156.3^{\circ} \mathrm{W}\right)$, a site representative of the Arctic region. The maximum in early spring is indicative of the Arctic haze phenomenon caused by long-range transport from northern midlatitudes, especially northern Europe and Russia [Bodhaine, 1995; 
(a) IMPROVE

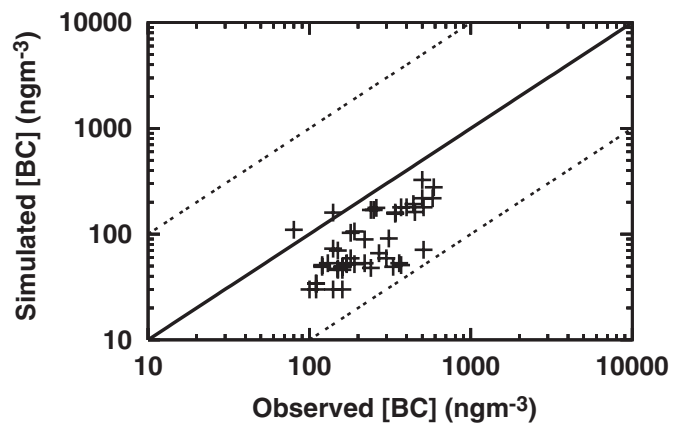

(c) Remote

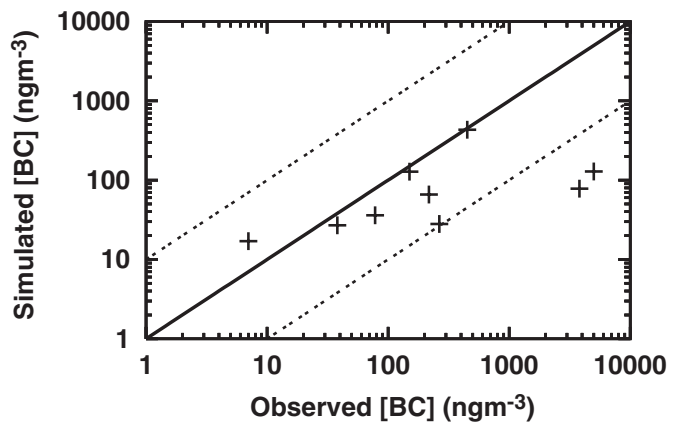

(b) Rural

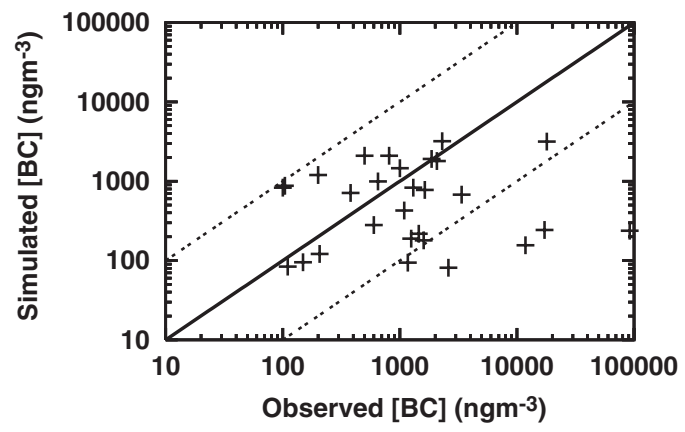

(d) Marine

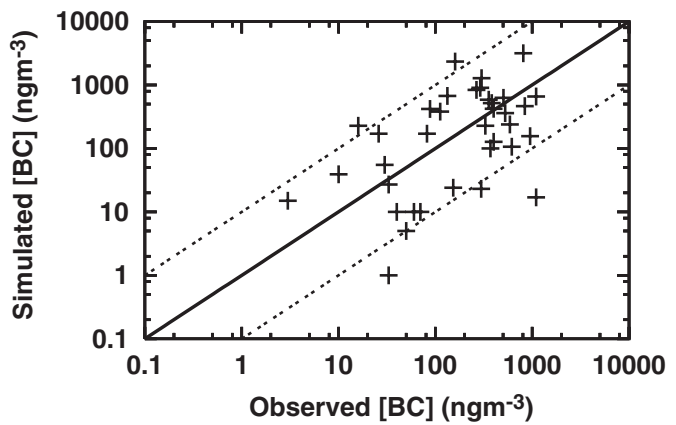

Figure 10. Simulated BC concentrations versus observations for (a) IMPROVE sites, (b) rural sites, (c) remote sites, and (d) marine sites. The dashed lines indicate 10:1 and 1:10 ratios.

Polissar et al., 1999]. Even though the simulation exhibits a small seasonal variation reflected in the observations, the simulated concentrations are as much as a factor of 4 less than observed values. A similar result was obtained by Liousse et al. [1996], who used the same BC emission inventory. Underprediction in the polar regions may be the result of underestimation of biomass sources. For example, boreal

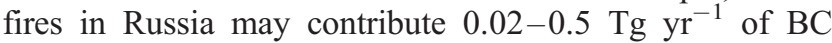

(a) IMPROVE

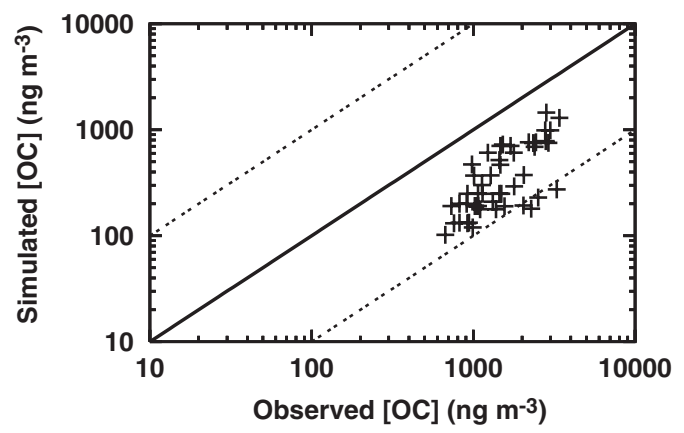

(c) Remote

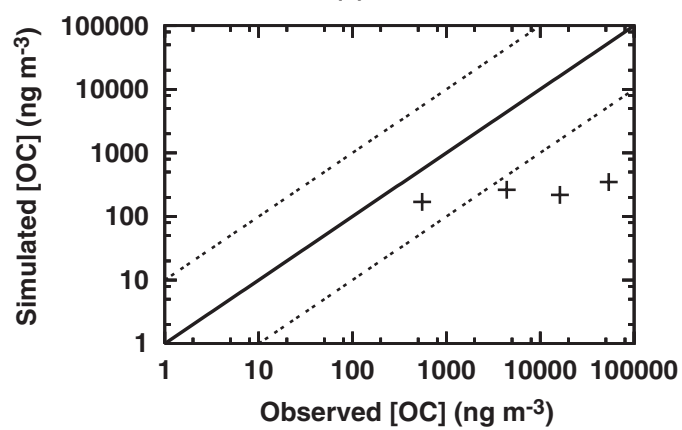

(b) Rural

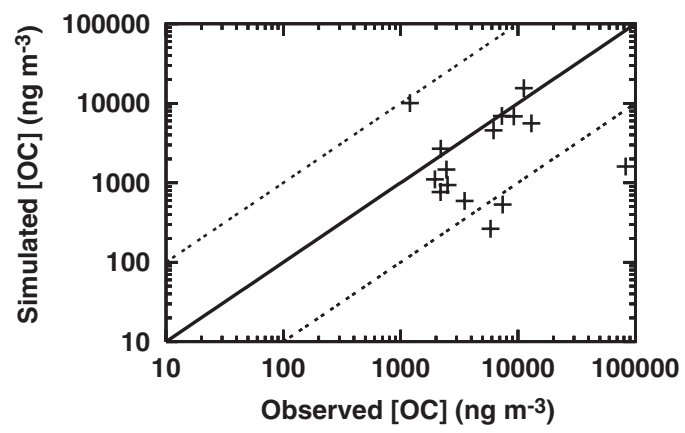

(d) Marine

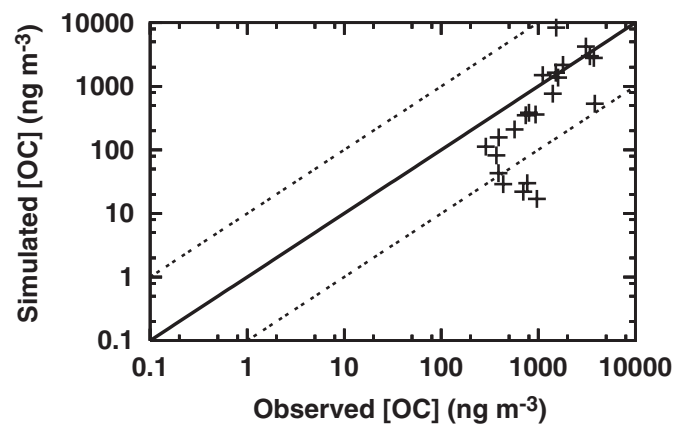

Figure 11. Simulated OC concentrations versus observations for (a) IMPROVE sites, (b) rural sites, (c) remote sites, and (d) marine sites. The dashed lines indicate 10:1 and 1:10 ratios. 
Table 10. Comparison of Simulated and Observed BC Concentrations in Rural Areas $\left(\mathrm{ng} \mathrm{m}^{-3}\right)$

\begin{tabular}{|c|c|c|c|c|c|c|c|}
\hline Location & Longitude & Latitude & Elevation $(\mathrm{km})$ & Time period & Observed & Simulated & Reference \\
\hline Abisko, Sweden & $18.5^{\circ} \mathrm{E}$ & $68.3^{\circ} \mathrm{N}$ & 0 & March-April & 206 & 157 & Noone and Clarke [1988] \\
\hline Allegheny Mountain, Pennsylvania & $79^{\circ} \mathrm{W}$ & $39^{\circ} \mathrm{N}$ & 0.82 & August & 1250 & 196 & Japar et al. [1986] \\
\hline Anadia, Portugal & $8.4^{\circ} \mathrm{W}$ & $40.3^{\circ} \mathrm{N}$ & 0 & August & 1594 & 147 & Castro et al. [1999] \\
\hline Aspvreten, Sweden & $17.4^{\circ} \mathrm{E}$ & $58.8^{\circ} \mathrm{N}$ & 0 & June-July & 100 & 1196 & Zappoli et al. [1999] \\
\hline Aveiro, Portugal & $8^{\circ} \mathrm{W}$ & $40^{\circ} \mathrm{N}$ & 0 & Annual & 11,800 & 141 & Nunes and Pio [1993] \\
\hline Bridgewater, Canada & $64.5^{\circ} \mathrm{W}$ & $44.4^{\circ} \mathrm{N}$ & 0 & August-November & 2600 & 87 & Chýlek et al. [1999] \\
\hline Central Africa & $17-19^{\circ} \mathrm{E}$ & $2-12^{\circ} \mathrm{N}$ & 0 & November-December & 3363 & 718 & Ruellan et al. [1999] \\
\hline Chebogue Point, Canada & $66^{\circ} \mathrm{W}$ & $43^{\circ} \mathrm{N}$ & 0 & August-September & 110 & 104 & Chýlek et al. [1999] \\
\hline Cheboygan County, Michigan & $84.7^{\circ} \mathrm{W}$ & $45.5^{\circ} \mathrm{N}$ & 0 & December-April & 600 & 279 & Cadle and Dasch [1988] \\
\hline Edgbaston, UK & $1^{\circ} \mathrm{W}$ & $51^{\circ} \mathrm{N}$ & 0 & Annual & 380 & 687 & Smith et al. [1996] \\
\hline Guayaquil, Ecuador & $79.9^{\circ} \mathrm{W}$ & $2.2^{\circ} \mathrm{S}$ & 0 & June & 520 & 662 & Andreae et al. [1984] \\
\hline Hemsby, England & $1.4^{\circ} \mathrm{E}$ & $52.4^{\circ} \mathrm{N}$ & 0 & Annual & 104 & 947 & Yaaqub et al. [1991] \\
\hline \multirow[t]{3}{*}{ Ivory Coast Savannah } & $5.1^{\circ} \mathrm{W}$ & $6.2^{\circ} \mathrm{N}$ & 0 & Annual & 1300 & 812 & $\begin{array}{c}\text { Wolff and Cachier [1998], } \\
\text { Cachier et al. [1990] }\end{array}$ \\
\hline & & & & Winter & 1867 & 1921 & Cachier et al. [1989] \\
\hline & & & & Fall & 200 & 1131 & Cachier et al. [1989] \\
\hline \multirow[t]{2}{*}{ K-puszta, Hungary } & $19.5^{\circ} \mathrm{E}$ & $46.9^{\circ} \mathrm{N}$ & 0 & July-August & 500 & 2065 & $\begin{array}{l}\text { Molnár et al. [1999], } \\
\text { Zappoli et al. [1999] }\end{array}$ \\
\hline & & & & Annual & 810 & 2173 & $\begin{array}{l}\text { Heintzenberg and } \\
\text { Mészáros [1985] }\end{array}$ \\
\hline Lahore, Pakistan & $74^{\circ} \mathrm{E}$ & $31^{\circ} \mathrm{N}$ & 0 & Annual & 17,200 & 235 & Smith et al. [1996] \\
\hline Laurel Hill, Pennsylvania & $79^{\circ} \mathrm{W}$ & $40^{\circ} \mathrm{N}$ & 0.85 & August & 1450 & 217 & Japar et al. [1986] \\
\hline Lin-an station, China & $119.7^{\circ} \mathrm{E}$ & $30.8^{\circ} \mathrm{N}$ & 0 & July-September & 2070 & 1814 & Parungo et al. [1994] \\
\hline Melpitz, Germany & $12^{\circ} \mathrm{E}$ & $51^{\circ} \mathrm{N}$ & 0 & Annual & 2300 & 3314 & Heintzenberg et al. [1998] \\
\hline Mt. Kanobili, Georgia & $42.7^{\circ} \mathrm{E}$ & $41.5^{\circ} \mathrm{N}$ & 2.00 & July & 1088 & 423 & Dzubay et al. [1984] \\
\hline Nylsvley Natural Reserve, So & $28.4^{\circ} \mathrm{E}$ & $24.7^{\circ} \mathrm{S}$ & 1.10 & May & 850 & 141 & Puxbaum et al. [2000] \\
\hline Orogrande, New Mexico & $106^{\circ} \mathrm{W}$ & $34.3^{\circ} \mathrm{N}$ & 0 & December-January & 149 & 87 & Pinnick et al. [1993] \\
\hline Petten, the Netherlands & $3^{\circ} \mathrm{E}$ & $52.9^{\circ} \mathrm{N}$ & 0 & April & 1631 & 940 & Berner et al. [1996] \\
\hline Rautavaara, Finland & $28.3^{\circ} \mathrm{E}$ & $63.5^{\circ} \mathrm{N}$ & 0 & December & 650 & 1215 & Raunemaa et al. [1994] \\
\hline San Pietro Capofiume, Italy & $11.6^{\circ} \mathrm{E}$ & $44.7^{\circ} \mathrm{N}$ & 0 & September-October & 1000 & 1327 & Zappoli et al. [1999] \\
\hline Tábua, Portugal & $17^{\circ} \mathrm{W}$ & $33^{\circ} \mathrm{N}$ & 0 & July-August & 1167 & 57 & Castro et al. [1999] \\
\hline Wageninen, the Netherlands & $5.7^{\circ} \mathrm{E}$ & $52^{\circ} \mathrm{N}$ & 0 & January & 18,000 & 2849 & Janssen et al. [1997] \\
\hline West Mountain, China & $116^{\circ} \mathrm{E}$ & $40^{\circ} \mathrm{N}$ & 0 & July-September & 91,711 & 251 & Parungo et al. [1994] \\
\hline
\end{tabular}

[Lavoué et al., 2000], which is not included in the present inventory. Other possible explanations include overestimation of wet scavenging and inaccurate representation of advection to the polar regions by the GCM. Figure $12 \mathrm{~b}$ shows comparison of predictions and observations at Alert, Canada $\left(82.5^{\circ} \mathrm{N}, 62.3^{\circ} \mathrm{W}\right)$, another high Arctic site. Observed $\mathrm{BC}$ concentrations and seasonality are similar to those of Barrow, Alaska. Again, BC concentrations are underpredicted.

[37] Figure 12c compares the $\mathrm{BC}$ observations and predictions at Jungfraujoch, Switzerland $\left(46.5^{\circ} \mathrm{N}, 8.0^{\circ} \mathrm{E}, 3.45\right.$ $\mathrm{km}$ above sea level (asl)), a site that is predominantly in the free troposphere [Nyeki et al., 1998]. Both observations and predictions exhibit a minimum during the winter months and maximum concentrations almost an order of magnitude greater than the minimum. Observations show a peak in
April and a larger peak in July. The peaks are reproduced by the simulations, but offset by 1 and 2 months, respectively, possibly because of representation of the atmospheric boundary layers by the GCM. The seasonal cycle results from vertical transport of boundary layer air masses from the Swiss Plateau to the Jungfraujoch due to enhanced thermal convection, which occurs more frequently during spring and summer [Baltensperger et al., 1997; Lugauer et al., 1998; Lavanchy et al., 1999]. During winter, the air mass is decoupled from the boundary layer, resulting in considerably lower $\mathrm{BC}$ concentrations indicative of those of the free troposphere.

[38] Figure 12d compares the predicted and observed $\mathrm{BC}$ concentrations at Mace Head, Ireland $\left(53.3^{\circ} \mathrm{N}, 9.9^{\circ} \mathrm{W}\right)$. The data at this site were taken on an almost continuous basis from February 1989 to June 1996. Located on the west

Table 11. Comparison of Simulated and Observed BC Concentrations in Remote Areas $\left(\mathrm{ng} \mathrm{m}^{-3}\right)$

\begin{tabular}{|c|c|c|c|c|c|c|c|}
\hline Location & Longitude & Latitude & Elevation $(\mathrm{km})$ & Time period & Observed & Simulated & Reference \\
\hline Mt. Krvavec, Slovenia & $14.5^{\circ} \mathrm{E}$ & $46.3^{\circ} \mathrm{N}$ & 1.74 & $\begin{array}{l}\text { December } \\
\text { July }\end{array}$ & $\begin{array}{l}150 \\
450\end{array}$ & $\begin{array}{c}74 \\
273\end{array}$ & Bizjak et al. [1999] \\
\hline Mt. Mitchell, North Carolina & $82.3^{\circ} \mathrm{W}$ & $35.7^{\circ} \mathrm{N}$ & 2.04 & Annual & 217 & 74 & Bahrmann and Saxena [1998] \\
\hline Mt. Sonnblick, Austria & $13^{\circ} \mathrm{E}$ & $47^{\circ} \mathrm{N}$ & 3.10 & $\begin{array}{c}\text { July } \\
\text { September }\end{array}$ & $\begin{array}{l}5000 \\
3800\end{array}$ & $\begin{array}{l}79 \\
51\end{array}$ & Hitzenberger et al. [1999] \\
\hline Ostrov Golomyanny, Russia & $90.6^{\circ} \mathrm{E}$ & $79.5^{\circ} \mathrm{N}$ & 0 & March-May & 265 & 23 & Polissar [1993] \\
\hline Spitsbergen, Norway & $11.9^{\circ} \mathrm{E}$ & $78.9^{\circ} \mathrm{N}$ & 0 & $\begin{array}{l}\text { October-May } \\
\text { May-October }\end{array}$ & $\begin{array}{c}78 \\
7\end{array}$ & $\begin{array}{l}37 \\
18\end{array}$ & Heintzenberg and Leck [1994] \\
\hline Wrangle Island, Russia & $179.6^{\circ} \mathrm{W}$ & $71^{\circ} \mathrm{N}$ & 0 & March-May & 38 & 23 & Hansen et al. [1991] \\
\hline
\end{tabular}


Table 12. Comparison of Simulated and Observed BC Concentrations in Marine Areas $\left(\mathrm{ng} \mathrm{m}^{-3}\right)$

\begin{tabular}{|c|c|c|c|c|c|c|}
\hline Location & Longitude & Latitude & Time Period & Observed & Simulated & Reference \\
\hline Arctic Region & $15^{\circ} \mathrm{W}-50^{\circ} \mathrm{E}$ & $74-83^{\circ} \mathrm{N}$ & July-September & 3 & 16 & Heintzenberg [1982] \\
\hline \multirow[t]{3}{*}{ Areão, Portugal } & $8.8^{\circ} \mathrm{W}$ & $40.5^{\circ} \mathrm{N}$ & Annual & 950 & 141 & Pio et al. [1996] \\
\hline & & & Summer & 589 & 164 & Castro et al. [1999] \\
\hline & & & Winter & 370 & 109 & \\
\hline Atlantic Ocean & $7-15^{\circ} \mathrm{W}$ & $29-41^{\circ} \mathrm{N}$ & June-July & 400 & 95 & Novakov et al. [2000] \\
\hline Atlantic Ocean (North) & $21^{\circ} \mathrm{W}-20^{\circ} \mathrm{E}$ & $52-79^{\circ} \mathrm{N}$ & July-September & 88 & 464 & Polissar [1992] \\
\hline Atlantic Ocean (Northeast) & $20^{\circ} \mathrm{E}-50^{\circ} \mathrm{W}$ & $50-80^{\circ} \mathrm{N}$ & October-November & 112 & 405 & O'Dowd et al. [1993] \\
\hline Sargasso Sea & $50^{\circ} \mathrm{W}$ & $30^{\circ} \mathrm{N}$ & July & 60 & 10 & Chesselet et al. [1981] \\
\hline \multirow[t]{2}{*}{ Bermuda } & $64.5^{\circ} \mathrm{W}$ & $32.2^{\circ} \mathrm{N}$ & January-February & 30 & 51 & Wolff et al. [1986] \\
\hline & & & August & 40 & 15 & \\
\hline Boistö Island & $26.5^{\circ} \mathrm{E}$ & $60.3^{\circ} \mathrm{N}$ & June & 525 & 498 & Raunemaa et al. [1993] \\
\hline Corsica, France & $9^{\circ} \mathrm{E}$ & $42^{\circ} \mathrm{N}$ & Spring & 383 & 593 & Cachier et al. [1989] \\
\hline \multirow[t]{4}{*}{ South Uist, UK } & $7^{\circ} \mathrm{W}$ & $57^{\circ} \mathrm{N}$ & Winter & 16 & 313 & Loew et al. [1996] \\
\hline & & & Summer & 26 & 176 & \\
\hline & & & Winter & 328 & 313 & \\
\hline & & & Summer & 82 & 176 & \\
\hline Western Mediterranean & $0-10^{\circ} \mathrm{E}$ & $36-46^{\circ} \mathrm{N}$ & Annual & 400 & 427 & Cachier et al. [1990] \\
\hline Chichi-jima, Japan & $142^{\circ} \mathrm{E}$ & $27^{\circ} \mathrm{N}$ & December & 614 & 90 & Ohta and Okita [1984] \\
\hline Enewetak Atoll & $162^{\circ} \mathrm{E}$ & $11^{\circ} \mathrm{N}$ & April & 50 & 6 & Cachier et al. [1990] \\
\hline Hachijo-jima, Japan & $139.8^{\circ} \mathrm{E}$ & $33.1^{\circ} \mathrm{N}$ & December-January & 838 & 485 & Ohta and Okita [1984] \\
\hline \multirow[t]{3}{*}{ Cheju Island, Korea } & $127.2^{\circ} \mathrm{E}$ & $33.3^{\circ} \mathrm{N}$ & December-March & 300 & 1267 & Kim et al. [2000] \\
\hline & & & July-October & 290 & 807 & \\
\hline & & & July-August & 266 & 751 & \\
\hline \multirow[t]{17}{*}{ Pacific Ocean } & $132-139^{\circ} \mathrm{E}$ & $32-34^{\circ} \mathrm{N}$ & December & 1100 & 612 & Ohta and Okita [1984] \\
\hline & $145-155^{\circ} \mathrm{W}$ & $20^{\circ} \mathrm{N}$ & August & 1100 & 16 & Andreae et al. [1984] \\
\hline & $120^{\circ} \mathrm{W}$ & $0^{\circ}$ & July & 10 & 38 & \\
\hline & $125-128^{\circ} \mathrm{E}$ & $28-32^{\circ} \mathrm{N}$ & December & 133 & 588 & Parungo et al. [1994] \\
\hline & $124-129^{\circ} \mathrm{E}$ & $27-33^{\circ} \mathrm{N}$ & October-November & 505 & 640 & \\
\hline & $126-129^{\circ} \mathrm{E}$ & $27-32^{\circ} \mathrm{N}$ & April-May & 355 & 464 & \\
\hline & $140-165^{\circ} \mathrm{E}$ & $0^{\circ}$ & June & 9 & 0 & \\
\hline & $165^{\circ} \mathrm{E}$ & $10^{\circ} \mathrm{N}$ & July & 25 & 0 & \\
\hline & $175^{\circ} \mathrm{E}$ & $8-18^{\circ} \mathrm{S}$ & September & 101 & 4 & Kaneyasu and Murayama [2000] \\
\hline & $175^{\circ} \mathrm{E}$ & $8 \mathrm{~S}-25^{\circ} \mathrm{N}$ & September-October & 33 & 1 & \\
\hline & $175^{\circ} \mathrm{E}$ & $22-8^{\circ} \mathrm{N}$ & April-May & 70 & 11 & \\
\hline & $175^{\circ} \mathrm{E}$ & $8-15^{\circ} \mathrm{S}$ & April-May & 40 & 0 & \\
\hline & $175^{\circ} \mathrm{E}$ & $30-35^{\circ} \mathrm{N}$ & May-June & 297 & 24 & \\
\hline & $175^{\circ} \mathrm{E}$ & $44-48^{\circ} \mathrm{N}$ & May-June & 153 & 27 & \\
\hline & $175^{\circ} \mathrm{E}$ & $5.7^{\circ} \mathrm{S}$ & September-October & 29 & 0 & \\
\hline & $175^{\circ} \mathrm{E}$ & $6.0^{\circ} \mathrm{N}$ & September-October & 37 & 0 & \\
\hline & $175^{\circ} \mathrm{E}$ & $5.3^{\circ} \mathrm{S}$ & May-June & 22 & 0 & \\
\hline China Sea & $113^{\circ} \mathrm{E}$ & $10^{\circ} \mathrm{N}$ & June & 33 & 22 & Parungo et al. [1994] \\
\hline Fuji Island, Japan & $175^{\circ} \mathrm{E}$ & $15.7^{\circ} \mathrm{S}$ & September & 113 & 4 & Kaneyasu and Murayama [2000] \\
\hline \multirow[t]{2}{*}{ San Nicolas Island, USA } & $119.3^{\circ} \mathrm{E}$ & $33.15^{\circ} \mathrm{N}$ & June-September & 160 & 2232 & Chow et al. [1994] \\
\hline & & & November-December & 810 & 3153 & \\
\hline
\end{tabular}

coast of Ireland, Mace Head is right on the western border of a GCM grid cell that covers most of Ireland (the grid box covers $5-10^{\circ} \mathrm{W}$ in longitude); the predictions shown in Figure $12 \mathrm{~d}$, therefore, include strong anthropogenic influence. The meteorology of Mace Head, however, is dominated by relatively unpolluted westerly and southwesterly winds from over the northern Atlantic Ocean [Cooke et al., 1997]. In Figure 12d, observational data from the clean sector and the continental sector are shown separately. BC concentrations from the continental sector are an order of magnitude higher than those from the clean sector and are in better agreement with the simulations; however, the predictions are still too high. One concludes that the BC emission inventory is likely too high in Europe. For example, fossil fuel emissions in Europe from the current inventory are almost three times the amount predicted by Bond [2000]. The maximum BC concentration at Mace Head in February is likely the result of increased fossil fuel emission from domestic heating during winter. Cooke et al. [1997] have suggested that the BC peak in May observed in both the clean and continental sectors is probably a result of reduced wet scavenging at that time. This secondary peak is not reproduced by the simulation. Moreover, Koch [2001] indicates that $\mathrm{BC}$ concentrations at this site are very sensitive to wet scavenging.

[39] Figure 12e compares $\mathrm{BC}$ predictions and observations at Mauna Loa, Hawaii $\left(19.3^{\circ} \mathrm{N}, 155.4^{\circ} \mathrm{W}, 3.4 \mathrm{~km}\right.$ asl). This site is often representative of midtroposphere conditions, particularly during nighttime downslope winds [Mendonca, 1969]. The observed springtime maximum in $\mathrm{BC}$ is attributable to long-range transport from the Asian continent, as evidenced by dust levels [Darzi and Winchester, 1982; Harris and Kahl, 1990]. As compared to the observations, the predicted peak in $\mathrm{BC}$ is delayed by 2 months and is somewhat lower. It has been noted that during strong dust episodes, dust can account for as much as $20 \%$ of the total measured absorption, thus contributing to absorption measurements (using an aethalometer) from which $\mathrm{BC}$ concentrations are inferred [Bodhaine, 1995].

[40] Finally, Figure $12 \mathrm{f}$ shows the seasonality of $\mathrm{BC}$ concentrations at Sapporo, Japan $\left(43^{\circ} \mathrm{N}, 141^{\circ} \mathrm{E}\right)$. Here the 
Table 13. Comparison of Simulated and Observed OC Concentrations in Rural Areas $\left(\mathrm{ng} \mathrm{C} \mathrm{m}^{-3}\right)$

\begin{tabular}{|c|c|c|c|c|c|c|c|}
\hline Location & Longitude & Latitude & Elevation $(\mathrm{km})$ & Time period & Observed & Simulated & Reference \\
\hline Allegheny Mountain, Pennsylvania & $79^{\circ} \mathrm{W}$ & $39^{\circ} \mathrm{N}$ & 0.82 & August & 2190 & 763 & Japar et al. [1986] \\
\hline Anadia, Portugal & $8.4^{\circ} \mathrm{W}$ & $40.3^{\circ} \mathrm{N}$ & 0 & August & 3506 & 591 & Castro et al. [1999] \\
\hline Aspvreten, Sweden & $17.4^{\circ} \mathrm{E}$ & $58.8^{\circ} \mathrm{N}$ & 0 & June-July & 2200 & 2681 & Zappoli et al. [1999] \\
\hline Aveiro, Portugal & $8^{\circ} \mathrm{W}$ & $40^{\circ} \mathrm{N}$ & 0 & Annual & 7400 & 531 & Nunes and Pio [1993] \\
\hline Central Africa & $17-19^{\circ} \mathrm{E}$ & $2-12^{\circ} \mathrm{N}$ & 0 & November-December & 13,021 & 5598 & Ruellan et al. [1999] \\
\hline Cheboygan County, Michigan & $84.7^{\circ} \mathrm{W}$ & $45.5^{\circ} \mathrm{N}$ & 0 & December-April & 1960 & 1101 & Cadle and Dasch [1988] \\
\hline Guayaquil, Ecuador & $79.9^{\circ} \mathrm{W}$ & $2.2^{\circ} \mathrm{S}$ & 0 & June & 510 & 6171 & Andreae et al. [1984] \\
\hline \multirow[t]{3}{*}{ Ivory Coast Savannah } & $5.1^{\circ} \mathrm{W}$ & $6.2^{\circ} \mathrm{N}$ & 0 & Annual & 9200 & 6852 & $\begin{array}{l}\text { Wolff and Cachier [1998], } \\
\text { Cachier et al. [1990] }\end{array}$ \\
\hline & & & & Winter & 11,233 & 15,539 & Cachier et al. [1989] \\
\hline & & & & Fall & 1200 & 10,044 & \\
\hline K-puszta, Hungary & $19.5^{\circ} \mathrm{E}$ & $46.9^{\circ} \mathrm{N}$ & 0 & July-August & 7300 & 6924 & $\begin{array}{l}\text { Molnár et al. [1999], } \\
\text { Zappoli et al. [1999] }\end{array}$ \\
\hline Lahore, Pakistan & $74^{\circ} \mathrm{E}$ & $31^{\circ} \mathrm{N}$ & 0 & Annual & 82,800 & 1605 & Smith et al. [1996] \\
\hline Laurel Hill, Pennsylvania & $79^{\circ} \mathrm{W}$ & $40^{\circ} \mathrm{N}$ & 0.85 & August & 2510 & 935 & Japar et al. [1986] \\
\hline Mt. Kanobili, Georgia & $42.7^{\circ} \mathrm{E}$ & $41.5^{\circ} \mathrm{N}$ & 2.00 & July & 2460 & 1464 & Dzubay et al. [1984] \\
\hline Tábua, Portugal & $17^{\circ} \mathrm{W}$ & $33^{\circ} \mathrm{N}$ & 0 & July-August & 5833 & 264 & Castro et al. [1999] \\
\hline
\end{tabular}

observations are an order of magnitude higher than predictions. Sapporo is an urban site, whereas GCM grid cell includes the surrounding rural and marine areas as well. The limitations of comparing point observations with grid-cell average GCM predictions are exemplified in this case.

[41] Figure 13 shows the comparison between observed and simulated $\mathrm{BC}$ concentrations at four different sites in the $\mathrm{SH}$. Figure $13 \mathrm{a}$ shows $\mathrm{BC}$ concentrations at the subAntarctic site of Amsterdam Island $\left(38^{\circ} \mathrm{S}, 77^{\circ} \mathrm{E}\right)$. Here the seasonal cycle is dominated by biomass burning emissions, which are dominant from June to August, a trend matched by the predictions. The lower-than-expected $\mathrm{BC}$ predictions suggest that either emissions are understated or wet scavenging is overstated.

[42] Figure 13b shows the annual cycle of BC concentrations at Amundsen-Scott Station, South Pole $\left(89^{\circ} \mathrm{S}\right.$, $102^{\circ} \mathrm{W}, 2.8 \mathrm{~km}$ asl). The simulation produces a peak in spring that appears in the data; however, the simulated peak concentration is three times higher than that observed. The low observed $\mathrm{BC}$ concentrations observed is likely a consequence of the measurement technique. $\mathrm{BC}$ concentrations were inferred from light attenuation measurements using an aethalometer [Hansen et al., 1982; Bodhaine, 1995]. The attenuation cross section can vary by a factor of 3 from that used in the calibration, due to varying particle shape and surface coating. Remote BC particles have on average lower cross sections, implying that concentrations from the aethalometer are lower than the true values [Liousse et al., 1993]. The spring maximum is most likely a result of increased long-range continental transport when the circumpolar vortex breaks down together with simultaneous biomass burning in the SH. Observational data indicate a peak in January that is not evident in the simulation. Advection toward the South Pole might be inaccurately represented. A similar seasonal trend is observed at another Antarctic site, Halley $\left(75.6^{\circ} \mathrm{S}, 26.2^{\circ} \mathrm{W}\right)$ (Figure $13 \mathrm{c}$ ). There the observed $\mathrm{BC}$ is higher because the location is closer to the source regions, and a smaller cross section is used to infer the aethalometer measurements. The underprediction again suggests either that emissions are too low or that wet deposition is too strong.

[43] Figure $13 \mathrm{~d}$ shows comparison of $\mathrm{BC}$ concentrations at another remote $\mathrm{SH}$ site, the Australian Baseline Atmospheric Pollution Monitoring Station at Cape Grim, Tasmania $\left(40.7^{\circ} \mathrm{S}, 144.7^{\circ} \mathrm{E}\right)$. The observation data include only the clean air sector [Heintzenberg and Bigg, 1990] and are lower than predicted. The relevant GCM grid cell covers most of Tasmania. According to Heintzenberg and Bigg [1990], the seasonality of BC concentrations at Cape Grim is a result of that of biomass mass burning in the SH. However, the observed peak in October occurs 2 months after the biomass burning peak. The predicted concentration tracks the biomass emission source strength, which peaks during June to August. The reason for this discrepancy is not known.

\subsection{Comparison With Previous Work}

\subsubsection{Black Carbon}

[44] Table 16 compares the global BC burdens and lifetimes predicted here with those of previous work. Among previous studies, Liousse et al. [1996] and Koch [2001] used the same BC emission inventory as this work. Compared to the work of Liousse et al. [1996], the global $\mathrm{BC}$ burden predicted here is 0.21 versus $0.13 \mathrm{Tg}$ with a longer lifetime (6.4 versus $4-4.5$ days). The difference

Table 14. Comparison of Simulated and Observed OC Concentrations in Remote Areas ( $\left.\mathrm{ng} \mathrm{C} \mathrm{m}^{-3}\right)$

\begin{tabular}{lccccccc}
\hline \multicolumn{1}{c}{ Location } & Longitude & Latitude & Elevation $(\mathrm{km})$ & Time period & Observed & Simulated & Reference \\
\hline El Yunque peak, Puerto Rico & $65.8^{\circ} \mathrm{W}$ & $18.3^{\circ} \mathrm{N}$ & 1.00 & April & 552 & 169 & Chesselet et al. $[1981]$ \\
Hotel Everest View, Nepal & $86.4^{\circ} \mathrm{E}$ & $27.5^{\circ} \mathrm{N}$ & 3.90 & December-January & 4400 & 262 & Davidson et al. [1986] \\
Mt. Sonnblick, Austria & $13^{\circ} \mathrm{E}$ & $47^{\circ} \mathrm{N}$ & 3.10 & July & 53,700 & 348 & Hitzenberger et al. $[1999]$ \\
& & & & September & 16,200 & 219 & \\
\hline
\end{tabular}




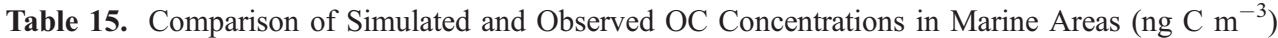

\begin{tabular}{|c|c|c|c|c|c|c|}
\hline Location & Longitude & Latitude & Time period & Observed & Simulated & Reference \\
\hline \multirow[t]{3}{*}{ Areão, Portugal } & \multirow[t]{3}{*}{$8.8^{\circ} \mathrm{W}$} & \multirow[t]{3}{*}{$40.5^{\circ} \mathrm{N}$} & Annual & 3830 & 531 & Pio et al. [1996] \\
\hline & & & Summer & 1410 & 764 & Castro et al. [1999] \\
\hline & & & Winter & 940 & 360 & \\
\hline Atlantic Ocean & $7-15^{\circ} \mathrm{W}$ & $29-41^{\circ} \mathrm{N}$ & June-July & 800 & 382 & Novakov et al. [2000] \\
\hline Sargasso Sea & $50^{\circ} \mathrm{W}$ & $30^{\circ} \mathrm{N}$ & July & 435 & 29 & Chesselet et al. [1981] \\
\hline \multirow[t]{4}{*}{ Bermuda } & \multirow[t]{4}{*}{$64.5^{\circ} \mathrm{W}$} & \multirow[t]{4}{*}{$32.2^{\circ} \mathrm{N}$} & January-February & 570 & 209 & Wolff et al. [1986] \\
\hline & & & May & 288 & 112 & Hoffman and Duce [1974] \\
\hline & & & June & 370 & 82 & Hoffman and Duce [1977] \\
\hline & & & August & 770 & 30 & Wolff et al. [1986] \\
\hline Cape San Juan, Puerto Rico & $66.1^{\circ} \mathrm{W}$ & $18.5^{\circ} \mathrm{N}$ & February-May & 391 & 157 & Novakov et al. [1997] \\
\hline Corsica, France & $9^{\circ} \mathrm{E}$ & $42^{\circ} \mathrm{N}$ & Spring & 1517 & 1641 & Cachier et al. [1989] \\
\hline Western Mediterranean & $0-10^{\circ} \mathrm{E}$ & $36-46^{\circ} \mathrm{N}$ & Annual & 1600 & 1369 & Cachier et al. [1990] \\
\hline Chichi-jima, Japan & $142^{\circ} \mathrm{E}$ & $27^{\circ} \mathrm{N}$ & December & 743 & 351 & Ohta and Okita [1984] \\
\hline \multirow[t]{2}{*}{ Enewetak Atoll } & \multirow[t]{2}{*}{$162^{\circ} \mathrm{E}$} & \multirow[t]{2}{*}{$11^{\circ} \mathrm{N}$} & April-May & 970 & 17 & Chesselet et al. [1981] \\
\hline & & & April & 700 & 22 & Cachier et al. [1990] \\
\hline Hachijo-jima, Japan & $139.8^{\circ} \mathrm{E}$ & $33.1^{\circ} \mathrm{N}$ & December-January & 1113 & 1501 & Ohta and Okita [1984] \\
\hline \multirow[t]{3}{*}{ Cheju Island, Korea } & \multirow[t]{3}{*}{$127.2^{\circ} \mathrm{E}$} & \multirow[t]{3}{*}{$33.3^{\circ} \mathrm{N}$} & December-March & 3100 & 4213 & Kim et al. [2000] \\
\hline & & & July-October & 3400 & 2976 & \\
\hline & & & July-August & 3734 & 2792 & Kim et al. [1999] \\
\hline Oahu, Hawaii, USA & $147.7^{\circ} \mathrm{W}$ & $21.4^{\circ} \mathrm{N}$ & July-October & 390 & 43 & Hoffman and Duce [1977] \\
\hline Pacific Ocean (coast of Japan) & $132-139^{\circ} \mathrm{E}$ & $32-34^{\circ} \mathrm{N}$ & December & 1800 & 2173 & Ohta and Okita [1984] \\
\hline \multirow[t]{2}{*}{ San Nicolas Island, USA } & \multirow[t]{2}{*}{$119.3^{\circ} \mathrm{E}$} & \multirow[t]{2}{*}{$33.15^{\circ} \mathrm{N}$} & June-September & 1530 & 8360 & Chow et al. [1994] \\
\hline & & & November-December & 100 & 10,912 & \\
\hline Tutuila Island, American Sam & $170.6^{\circ} \mathrm{W}$ & $14.3^{\circ} \mathrm{S}$ & June-August & 220 & 10 & Hoffman and Duce [1977] \\
\hline
\end{tabular}

arises because Liousse et al. [1996] assumed all BC to be hydrophilic, leading to more effective wet scavenging. The lower wet deposition rate in the present case leads to higher $\mathrm{BC}$ concentrations at high altitudes. The same explanation also accounts for the difference in global burden and lifetime between this work and that of Koch [2001], which also used the GISS GCM II-prime. For three cases studied by Koch [2001], in which in-cloud convective scavenging removes all soluble and insoluble aerosols, the lifetime of $\mathrm{BC}$ is predicted to be $4.28-4.44$ days. For the case in which only soluble aerosols are removed, as assumed here, the lifetime is predicted to be 8.42 days. The longer lifetime in the latter case results because all $\mathrm{BC}$ is assumed to be emitted as hydrophobic and ages from hydrophobic to hydrophilic as determined by the oxidation of $\mathrm{SO}_{2}$ by $\mathrm{OH}$. Koch [2001] assumed hydrophilic BC to be $90 \%$ soluble, as compared to $100 \%$ in our case. The global burden of BC as predicted by Cooke and Wilson [1996] is higher than that predicted here $(0.28$ versus $0.22 \mathrm{Tg})$, and their estimated lifetime is longer (6-10 versus 6.4 days). Cooke and Wilson [1996] used a larger emission inventory

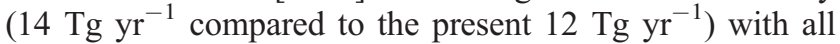
(compared to $80 \%$ in our case) BC emitted as hydrophobic aerosol and conversion to hydrophilic with a time constant of 0.8-1.6 days instead of 1.15 days. Cooke et al. [1999] considered only fossil fuel sources of BC, resulting in an expected lower global burden and a shorter lifetime of 5.3 days. They also used a different GCM and different dry deposition velocities.

\subsubsection{Primary Organic Aerosol}

[45] Table 17 compares the global POA burdens and lifetimes of our work and those of Cooke et al. [1999] and Koch [2001]. The smaller predicted global POA burden and shorter lifetime in the work of Koch [2001] are again a result of the different in-cloud convective scavenging schemes. Cooke et al. [1999] considered only fossil fuel sources of POA. Their predicted POA lifetime lies between those of our work and those of Koch [2001].

\subsubsection{Secondary Organic Aerosol}

[46] Estimated SOA production is $11.2 \mathrm{Tg} \mathrm{yr}^{-1}$, which is lower than the estimated range of $13-24 \mathrm{Tg} \mathrm{yr}^{-1}$ by Griffin et al. [1999a]. Direct comparison is, however, difficult since Griffin et al. [1999a] did not include three-dimensional transport, partitioning of SOA onto POA, or oxidation of parent hydrocarbons by $\mathrm{NO}_{3}$. For these reasons, the estimate of Griffin et al. [1999a] might be considered as a lower bound. If so, this suggests that the SOA production rate predicted in the present study is even lower than might have been expected. Indeed, if we neglect partitioning of SOA into POA, the SOA production rate is reduced by an order of magnitude and the global burden by half. The global burden is only a factor of two lower because of a longer lifetime. (In the absence of POA, gas-phase products remain in the gas phase and are transported away from the source region; therefore, more aerosols are formed at the upper troposphere where wet deposition is less prevalent.) If $\mathrm{NO}_{3}$ oxidation of parent hydrocarbons as a contribution to SOA is ignored, then global SOA production would be approximately $10 \mathrm{Tg} \mathrm{yr}^{-1}$, assuming that the parent hydrocarbons not oxidized by $\mathrm{NO}_{3}$ are oxidized by $\mathrm{O}_{3}$ and $\mathrm{OH}$ and form SOA at a lower yield.

[47] Our estimate of global SOA production is substantially lower than that of $61-79 \mathrm{Tg} \mathrm{yr}^{-1}$ by Kanakidou et al. [2000], the global burden corresponding to which is $1.2-$ $1.6 \mathrm{Tg}$, as compared to $0.19 \mathrm{Tg}$ in the present work. The source of this major discrepancy in global SOA predictions merits discussion.

[48] Kanakidou et al. [2000] made a number of assumptions in calculating SOA yield (see their equation (1)). First, they neglected transport of semivolatile gas-phase products away from source regions, which can form SOA at higher altitudes. The effect of this assumption is actually to under- 
(a) Barrow, Alaska

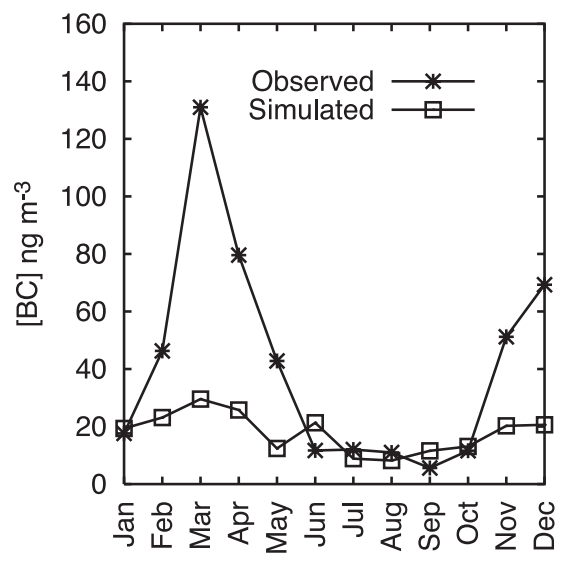

(c) Jungfraujoch, Switzerland

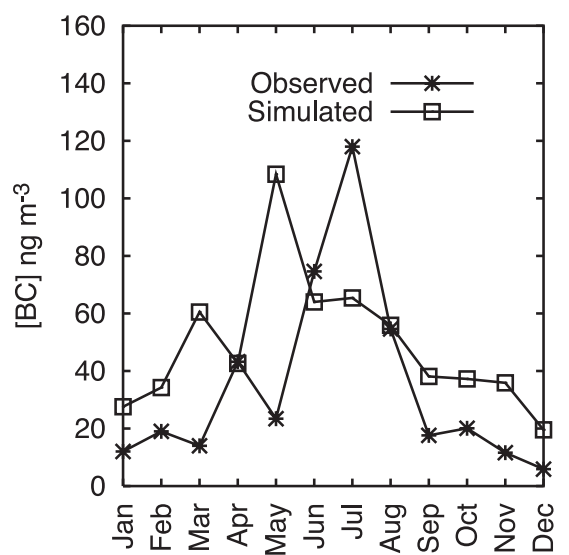

(e) Mauna Loa, Hawaii

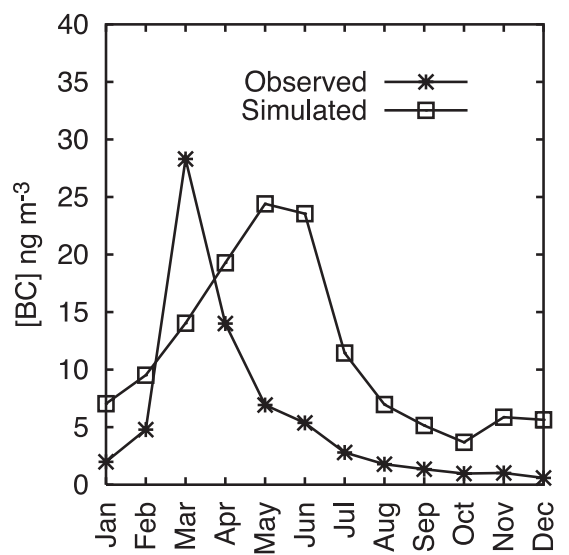

(b) Alert, Canada

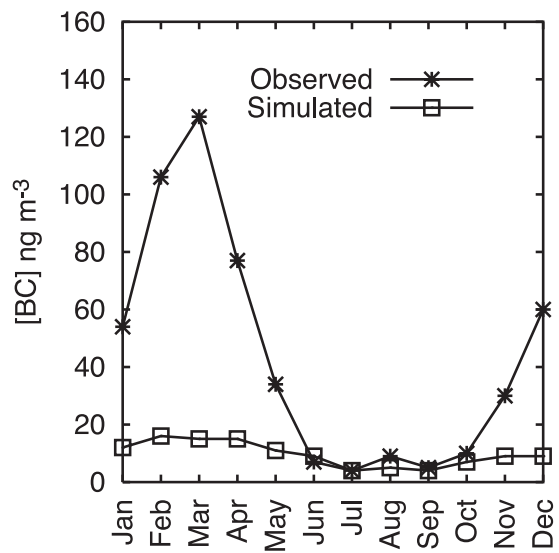

(d) Mace Head, Ireland

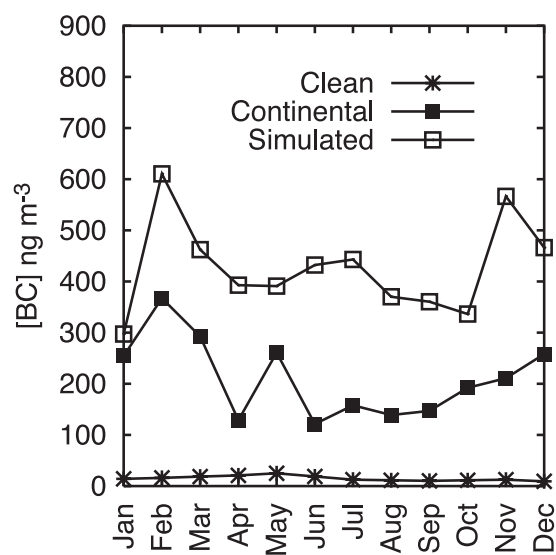

(f) Sapporo, Alaska

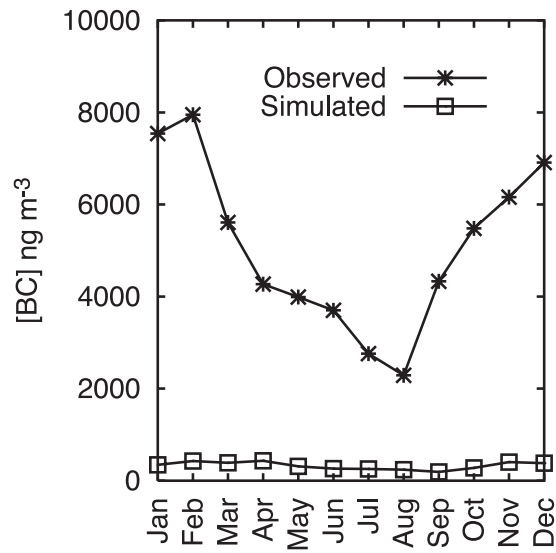

Figure 12. Seasonal cycle of $B C$ concentrations at various sites in the $\mathrm{NH}$ : (a) Barrow, Alaska $\left(71.2^{\circ} \mathrm{N}\right.$, $156.3^{\circ} \mathrm{W}$ ) [Bodhaine, 1995], (b) Alert, Canada $\left(82.5^{\circ} \mathrm{N}, 62.3^{\circ} \mathrm{W}\right)$ [Hopper et al., 1994], (c) Jungfraujoch, Switzerland $\left(46.5^{\circ} \mathrm{N}, 9^{\circ} \mathrm{E}, 3.45 \mathrm{~km}\right.$ asl $)$ [Nyeki et al., 1998], (d) Mace Head, Ireland $\left(53.3^{\circ} \mathrm{N}, 9.9^{\circ} \mathrm{W}\right)$ [Cooke et al., 1997], (e) Mauna Loa, Hawaii $\left(19.3^{\circ} \mathrm{N}, 155.4^{\circ} \mathrm{W}, 3.4 \mathrm{~km}\right.$ asl) [Bodhaine, 1995], and (f) Sapporo, Japan $\left(43^{\circ} \mathrm{N}, 141^{\circ} \mathrm{E}\right)[$ Ohta and Okita, 1990].

estimate SOA production. Second, they assumed that all SOA, once formed, remains in the condensed phase until removal by wet or dry deposition (so that the SOA formed from the previous time steps behaves as POA in the current time step). Because of gas-particle equilibrium, however, SOA can repartition back into the gas phase. For example, if an air parcel originally at equilibrium is advected to a region of higher temperature, some of the SOA will reevaporate to establish the new equilibrium state. We calculate that the combined effect of these two assumptions made by Kanakidou et al. [2000] is underestimation of SOA production by about $45 \%$. 
(a) Amsterdam Island, France

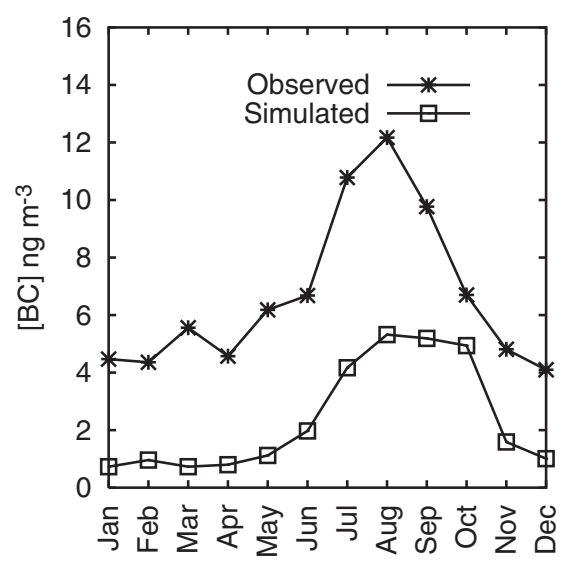

(c) Halley, Antarctica

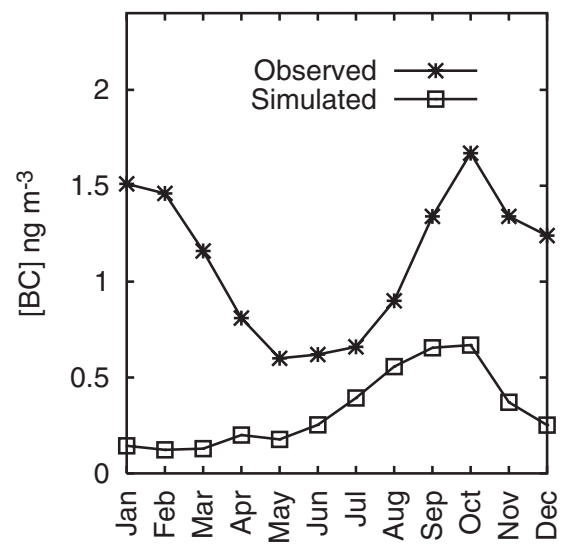

(b) Amundsen-Scott, South Pole

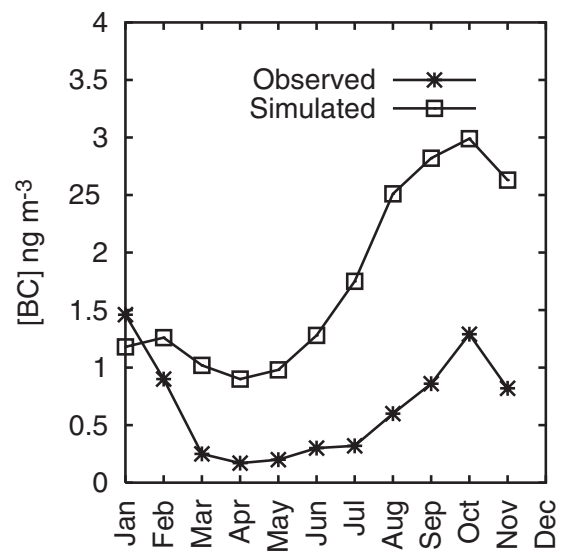

(d) Cape Grim, Tasmania

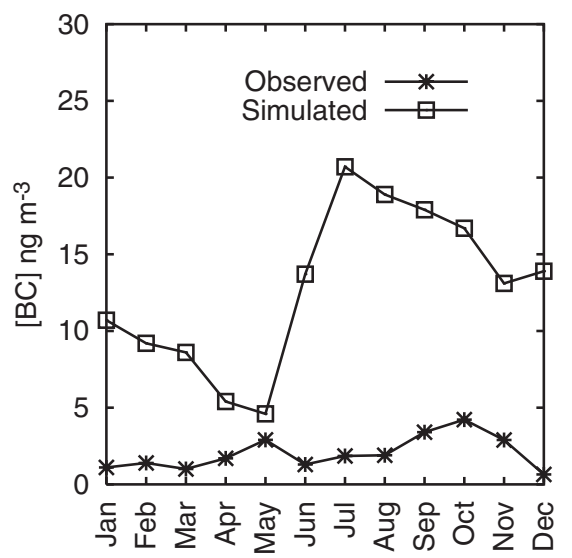

Figure 13. Seasonal cycle of $\mathrm{BC}$ concentrations at various sites in the SH: (a) Amsterdam Island, France $\left(38^{\circ} \mathrm{S}, 77^{\circ} \mathrm{E}\right)$ [Wolff and Cachier, 1998], (b) Amundsen-Scott Station, South Pole $\left(89^{\circ} \mathrm{S}, 102^{\circ} \mathrm{W}\right.$, 2.84 asl) [Bodhaine, 1995], (c) Halley, Antarctica $\left(75.6^{\circ} \mathrm{S}, 26.2^{\circ} \mathrm{W}\right)$ [Wolff and Cachier, 1998], and (d) Cape Grim, Tasmania $\left(40.7^{\circ} \mathrm{S}, 144.7^{\circ} \mathrm{E}\right)$ [Heintzenberg and Bigg, 1990].

[49] The emissions inventory used by Kanakidou et al. [2000] included $210 \mathrm{Tg} \mathrm{C} \mathrm{yr}^{-1}$ of biogenic hydrocarbons (127 $\mathrm{Tg} \mathrm{C} \mathrm{yr}^{-1}$ monoterpenes and $83 \mathrm{Tg} \mathrm{C} \mathrm{yr}^{-1}$ ORVOC), of which they assumed $50 \%$ to be $\alpha$-pinene and $50 \% \beta$-pinene. Assuming the molecular weight of ORVOCs is equal to that of monoterpenes, a total of $210 \mathrm{Tg} \mathrm{C} \mathrm{yr}^{-1}$ is equivalent to a total mass of $238 \mathrm{Tg} \mathrm{yr}^{-1}$, which is to be compared with the value of $201 \mathrm{Tg} \mathrm{yr}^{-1}$ in our work. The difference arises from a different percent contribution of ORVOCs to SOA formation and molecular weights of ORVOC. The average molarbased stoichiometric coefficient for SOA formation was assumed to be $\approx 0.34$, which equals 0.425 in mass-based units by assuming SOA has molecular weight of $170 \mathrm{~g}$ $\mathrm{mol}^{-1}$. Therefore, assuming all of the $\alpha$-pinene and $\beta$-pinene react, the maximum SOA production possible is $0.425 \times 238$ $=101 \mathrm{Tg} \mathrm{yr}^{-1}$. This is assuming that: (1) all oxidants $\mathrm{O}_{3}, \mathrm{OH}$ and $\mathrm{NO}_{3}$ contribute to $\mathrm{SOA}$ formation and (2) all products condense to the aerosol phase. Kanakidou et al. [2000] included $\mathrm{O}_{3}, \mathrm{OH}$, and $\mathrm{NO}_{3}$ oxidation as sinks for the parent hydrocarbons, but they considered only $\mathrm{O}_{3}$ reaction as sources of SOA formation. They predicted that $\mathrm{O}_{3}$ accounted for $\approx 80 \%$ of the oxidation of the parent hydrocarbons. Thus the maximum $\mathrm{SOA}$ production rate, neglecting any $\mathrm{NO}_{3}$ or
$\mathrm{OH}$ contribution, is $101 \times 0.8=81 \mathrm{Tg} \mathrm{yr}^{-1}$. Not all $81 \mathrm{Tg}$ $\mathrm{yr}^{-1}$ can be in the aerosol phase since thermodynamic equilibrium requires that

$$
\frac{A_{i, j, k}}{A_{i, j, k}+G_{i, j, k}}=\left(\frac{K_{o m, i, j, k} M_{o}}{1+K_{o m, i, j, k} M_{o}}\right)<1
$$

Even under the most favorable conditions for aerosol formation, $K_{o m, i, j, k}=0.2 \mu \mathrm{g}^{-1} \mathrm{~m}^{3}$ and $M_{o}=30 \mu \mathrm{g} \mathrm{m}^{-3}$, the above ratio is 0.86 . The predicted production rate of $61-79$ $\mathrm{Tg} \mathrm{yr}^{-1}$ means that the predicted ratio is 0.75 to 0.98 . However, $M_{o}$ is generally on the order of $0.1-1 \mu \mathrm{g} \mathrm{m}^{-3}$, so the above ratio should be about $0.02-0.16$.

[50] The same analysis above can be applied to our work.

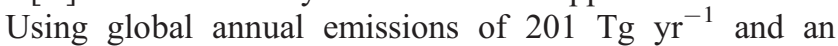
average mass-based stoichiometric coefficient of $\alpha=0.7$,

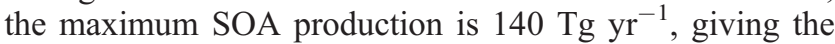
predicted ratio of aerosol-phase products to total products to be about 0.08 , which is more reasonable.

[51] Figure 14 shows a comparison of the current SOA prediction to that of the work of Andersson-Sköld and Simpson [2001] at four sites in the Nordic countries. Andersson-Sköld and Simpson [2001] used the Lagrangian 
Table 16. Comparison of Predicted BC Global Burdens and Lifetimes

\begin{tabular}{lcc}
\hline \multicolumn{1}{c}{ Reference } & Burden (Tg) & Lifetime (days) \\
\hline This work & 0.22 & 6.4 \\
Cooke and Wilson [1996] & 0.28 & $6-10$ \\
Liousse et al. [1996] & 0.13 & $4-4.5$ \\
Cooke et al. [1999] & $0.073^{\mathrm{a}}$ & $5.29^{\mathrm{a}}$ \\
Koch [2001] & $0.14-0.29^{\mathrm{b}}$ & $4.28-8.42^{\mathrm{b}}$ \\
\hline
\end{tabular}

${ }^{\mathrm{a}}$ Fossil fuel only.

${ }^{b}$ The range of estimates arises from different wet scavenging schemes.

EMEP (Cooperative Programme for Monitoring and Evaluation of the Long Range Transmission of Air Pollutants in Europe) oxidant model. The comparison is shown for the three cases studied by Andersson-Sköld and Simpson [2001] and for the months of January, April, July, and October for each of the four sites. The first case used the mechanism of [Kamens et al., 1999] for $\mathrm{O}_{3}$ oxidation of $\alpha$-pinene and did not include other terpenes (labeled "Kamens" on Figure 14). The second and third cases used similar emission inventory and aerosol parameters as our work. " $\alpha-\mathrm{K}$ " on Figure 14 uses the aerosol yield parameters of Griffin et al. [1999a]. " $\alpha-K-T$ " also uses the parameters given by Griffin et al. [1999a], but partition coefficients $K_{o m}$ are adjusted for temperature effects. In Figure 14 the predictions of Andersson-Sköld and Simpson [2001] are plotted against our predictions multiplied by 0.93 to account for the fact that they did not consider $\mathrm{NO}_{3}$ as a sink for terpenes. The factor of 0.93 approximates the lower aerosol yield of $\mathrm{O}_{3} / \mathrm{OH}$ oxidation if one allows the reactive hydrocarbons to be oxidized only by $\mathrm{O}_{3}$ and $\mathrm{OH}$. The factor of 0.93 represents an annual and global average, so it is only a first-order estimate for the effect of neglecting $\mathrm{NO}_{3}$ oxidation on $\mathrm{SOA}$ concentrations. This estimate also assumes that the lifetime of SOA does not change. The lifetime of SOA can change because wet scavenging is sensitive to precipitation rates, which vary with locations. As seen from Figure 14, the present predictions are in good agreement with those of the work of Andersson-Sköld and Simpson [2001], given the differences in gas-phase chemistry, model resolution, and meteorological conditions. The slightly higher levels predicted by Andersson-Sköld and Simpson [2001] may be a result of the fact that they used a stronger temperature dependence of $K_{\text {om }}$; we employ $\Delta H / R=5000 \mathrm{~K}$ in equation (4), whereas they used $\Delta H / R=9525 \mathrm{~K}$.

\subsection{Sources of Uncertainties in Global Burdens and Distributions}

[52] Global burdens and distributions are strongly dependent on a number of factors. First and foremost, they are sensitive to the emission inventories of primary carbonaceous

Table 17. Comparison of Predicted POA Global Burdens and Lifetimes

\begin{tabular}{lcc}
\hline \multicolumn{1}{c}{ Reference } & Burden (Tg) & Lifetime (days) \\
\hline This work & 1.2 & 5.3 \\
Cooke et al. [1999] & $0.11^{\mathrm{a}}$ & $4.54^{\mathrm{a}}$ \\
Koch [2001] & 0.95 & 3.86 \\
\hline
\end{tabular}

\footnotetext{
${ }^{\mathrm{a}}$ Fossil fuel only.
}

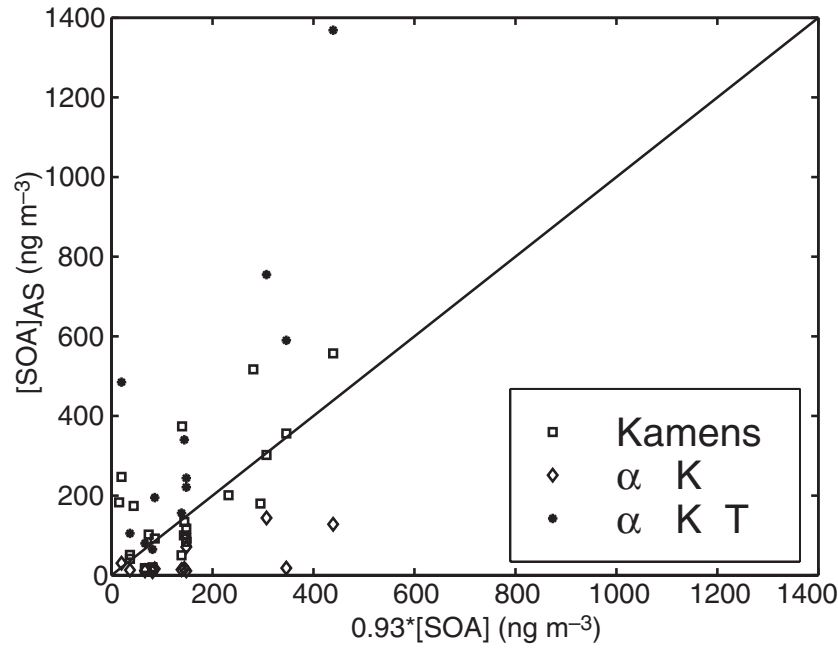

Figure 14. Comparison of predicted SOA concentrations with those of the work of Andersson-Sköld and Simpson [2001] for six sites in the Nordic countries. The abscissa is $93 \%$ of predicted SOA concentrations of this work (see text). The ordinate is the SOA concentrations predicted by Andersson-Sköld and Simpson [2001] for three different mechanisms. "Kamens" is based on the gas-phase reaction mechanisms of Kamens et al. [1999]. " $\alpha-K$ " is based on the aerosol yield parameters of Griffin et al. [1999a]. " $\alpha-K-T$ " is based on the same aerosol yield parameters but adjusted for temperature effects.

aerosols [Liousse et al., 1996]. The BC inventory from fossil fuel used in the present work is approximately 4 times less than that of the work of Cooke and Wilson [1996] in North America but comparable to that of Cooke et al. [1999]. The difference is a result of updated emission factors and fuel usage data. The global emissions of POA from fossil fuels employed here are a factor of two higher than those of the work of Cooke et al. [1999] because Liousse et al. [1996] assume that fossil fuel emissions of POA are proportional to the fossil fuel emissions of $\mathrm{BC}$ and that the proportionality constant is globally uniform.

[53] Uncertainties in the emissions of POA also have an effect on the predicted global burden and lifetime of SOA. For a given emission rate of biogenic hydrocarbons but less POA, more semivolatile oxidation products will stay in the gas phase and be transported away from the source regions. At higher altitudes, colder temperatures would eventually allow the some for the products to condense into the aerosol phase. Using the predicted global aerosol production of 11.2 $\mathrm{Tg} \mathrm{yr}^{-1}$ and assuming that all $201 \mathrm{Tg} \mathrm{yr}^{-1}$ parent hydrocarbons are oxidized, the overall global aerosol yield that we predict is

$$
Y=\approx \frac{11.2}{201}=0.05
$$

If we average the mass-based stoichiometric coefficients $\alpha_{i, j, j}$ 's listed in Table 3 and weigh them by emissions and reactivity, the average is $\alpha=0.7$. Since $\alpha \gg Y$, this means that the total organic aerosol concentration $M_{o}$ is in the regime where the total aerosol yield is very sensitive to $M_{o}$. In other words, SOA production is very sensitive to the 
concentrations of POA (and therefore to the emission rate of POA). As human activities continue to increase POA emissions, SOA production will likewise increase.

[54] Because aerosol-forming hydrocarbons are oxidized in the atmosphere virtually entirely, uncertainties in their emission inventory translate directly to uncertainties in SOA production. According to Guenther et al. [1995], uncertainties associated with monoterpene emissions in some temperate regions are at least a factor of 3 . Segmenting total monoterpene and ORVOC emissions into individual compounds and lumping into groups of reactants (Table 5) also contribute to the uncertainty. The contribution of individual compounds to the total monoterpene emission is not geographically constant as we have assumed. By grouping compounds with similar aerosol yield parameters and reactivities together according to Table 5, the contributions of each group of parent hydrocarbons to SOA formation (see Table 8) are roughly proportional to the emission rates multiplied by the mass-based stoichiometric coefficients. Uncertainties in the emissions of specific monoterpene would certainly lead to inaccuracy in the predicted global SOA production.

[55] The spatial resolution of the GCM also introduces uncertainties to the model prediction since physical processes such as emissions and transport often occur at a spatial scale smaller than the GCM grid cells. For example, the coarse resolution can introduce artificial dilution of emissions and lead to underestimation of aerosol concentrations.

[56] Another factor leading to uncertainty in prediction of global SOA production arises from the aerosol yield parameters. Available experimental data on $\alpha$ and $K_{o m}$ values for the biogenic hydrocarbons are for temperatures of about $298 \mathrm{~K}$. We have represented the temperature dependence of $K_{\text {om }}$, but temperature dependence of $\alpha$ is not taken into account. Implicitly assumed is that the nature of the reaction pathway and products remains unchanged at colder temperatures, an assumption that is likely not to be a source of serious error.

[57] Finally, uncertainties in wet scavenging lead to large uncertainties in global burden, lifetime, and distribution of any soluble tracer. The relevant parameters in the current study include the percentage of primary carbonaceous aerosols emitted that are hydrophobic and the scavenging efficiency (or solubility) of hydrophilic aerosols. More hydrophobic aerosols or lower scavenging efficiency lead to longer predicted lifetime, more aerosol in the upper troposphere, and a larger global burden. For the semivolatile gas-phase oxidation products, values of Henry's law coefficients are important. Lower Henry's law coefficients mean that more gas-phase products are transported to the upper troposphere, where colder temperatures allow the semivolatile gases to condense. This would also increase SOA concentrations in the polar regions.

\section{Preindustrial Versus Present-Day}

[58] For preindustrial BC and POA emissions, we assume only $10 \%$ of the current global emissions from biomass burning occurred in the preindustrial period and neglect all fossil fuel sources, resulting in 0.56 and $4.5 \mathrm{Tg} \mathrm{yr}^{-1}$ of $\mathrm{BC}$ and POA, respectively. The seasonal and geographical distributions of preindustrial $\mathrm{BC}$ and POA emissions are assumed to be the same as the present-day biomass emis- sions of carbon monoxide given by Wang et al. [1998a]. Preindustrial monthly mean concentrations of $\mathrm{OH}$ and $\mathrm{O}_{3}$ concentrations are available from the work of Mickley et al. [1999]. Although biogenic VOC emissions may have decreased since the 1800 s due to deforestation, we assume that the monoterpene and biogenic ORVOC emissions remain the same. Therefore, our preindustrial SOA calculation may lie in the low end of the possible range.

[59] The global distribution of preindustrial carbonaceous aerosol concentrations is shown in Figure 15. In contrast to the present-day, the average $\mathrm{BC}$ and POA concentrations are higher in the SH where biomass burning is more prominent. The relative increase since the preindustrial time is greater in the NH because of fossil fuel emissions. Total global burdens are estimated to have increased by almost an order of magnitude since preindustrial period (Table 18).

[60] For SOA, preindustrial concentrations are still predicted to be higher in the $\mathrm{NH}$, where biogenic emissions of VOC are higher. If we assumed that biogenic emissions of VOC remained constant and that VOCs are oxidized almost to completion even with lower ozone levels, the overall lower preindustrial SOA concentrations is mainly due to less POA available for absorption of SOA. The preindustrial SOA production rate is estimated to be $0.85 \mathrm{Tg} \mathrm{yr}^{-1}$, which is an order of magnitude of lower than present-day production. Interestingly, SOA concentrations in the upper troposphere are actually predicted to be slightly higher during the preindustrial time (Figure 15c). This prediction is explained by the semivolatile nature of SOA; with lower POA concentrations near the surface, more gas-phase products are transported to higher altitudes where they condense to the aerosol phase. This result again illustrates the sensitivity of SOA concentrations to wet deposition of gas-phase products and the temperature dependence of the partition coefficient, $K_{o m}$.

\section{Direct Radiative Forcing of Carbonaceous Aerosols}

[61] Radiative forcing is calculated as the difference in the incoming solar irradiance at the top of the atmosphere (TOA) with and without the presence of aerosols. We ne-glect longwave forcing as it is expected to be small [Haywood et al., 1997]. Direct aerosol radiative forcing is calculated online using the radiation model embedded in the GISS GCM II-prime [Lacis and Hansen, 1974; Hansen et al., 1983; Lacis and Mishchenko, 1995; Tegen et al., 2000]. Reflection, absorption, and transmission by aerosols are calculated using the single Gauss point doubling/adding radiative transfer model. The correlated $k$-distribution method is used to compute absorption by gases for 6 solar and 25 thermal intervals [Lacis and Oinas, 1991]. The radiation time step in the model is 5 hours. The radiative forcing calculations do not feed back into the GCM climate, so that the preindustrial and present-day simulations use the same meteorological fields.

[62] To include inorganic aerosols, present-day and preindustrial monthly sulfate fields and associated aerosol water computed with the GISS GCM II-prime are imported from the work of Adams et al. [2001].

\subsection{Aerosol Mixing State}

[63] The mixing state of carbonaceous aerosol is important in determining its radiative effect [Chyýlek et al., 1995; 

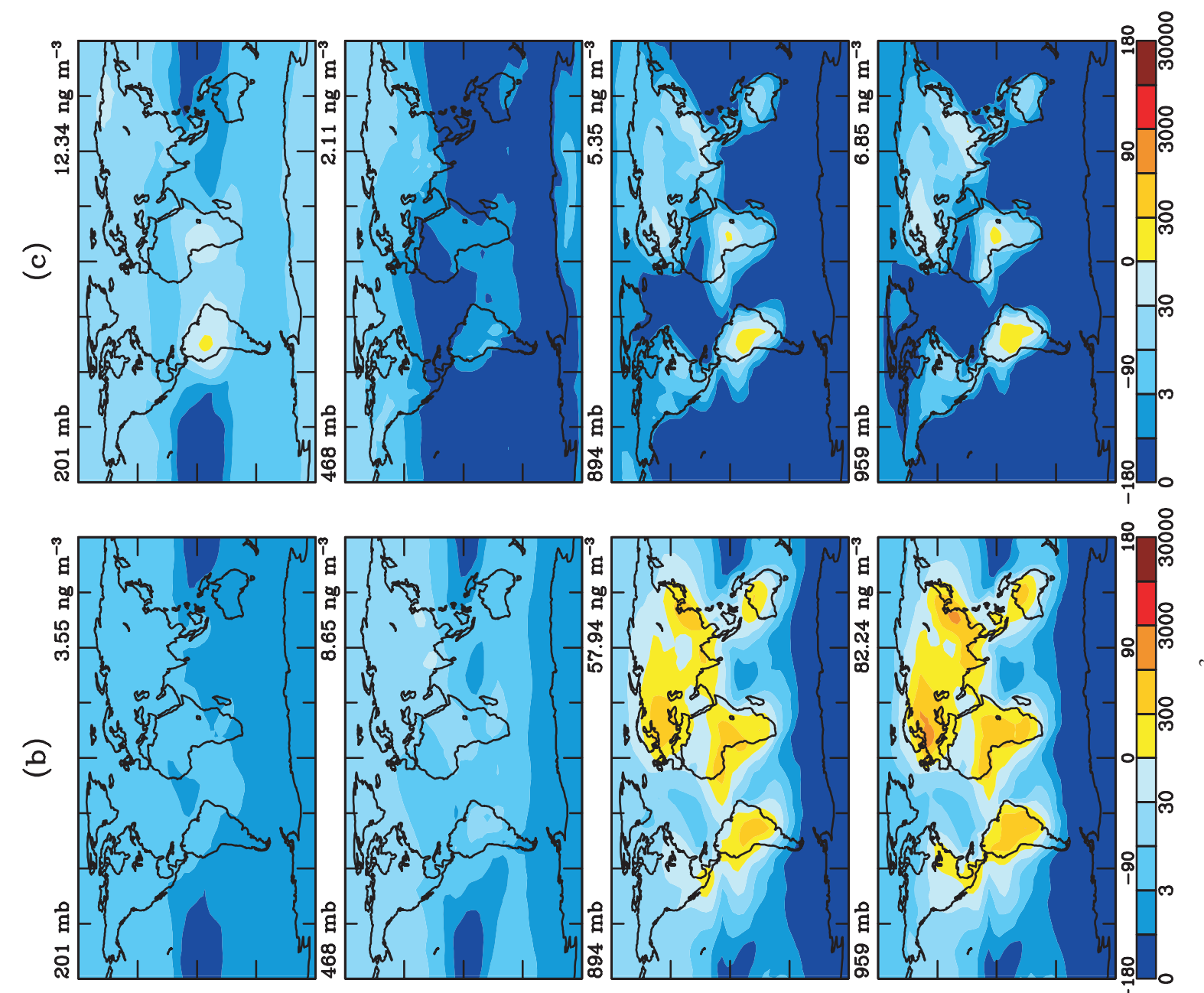

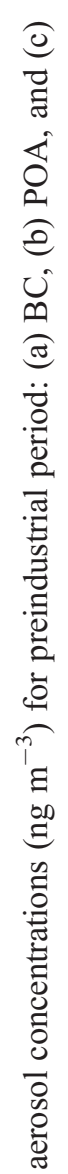
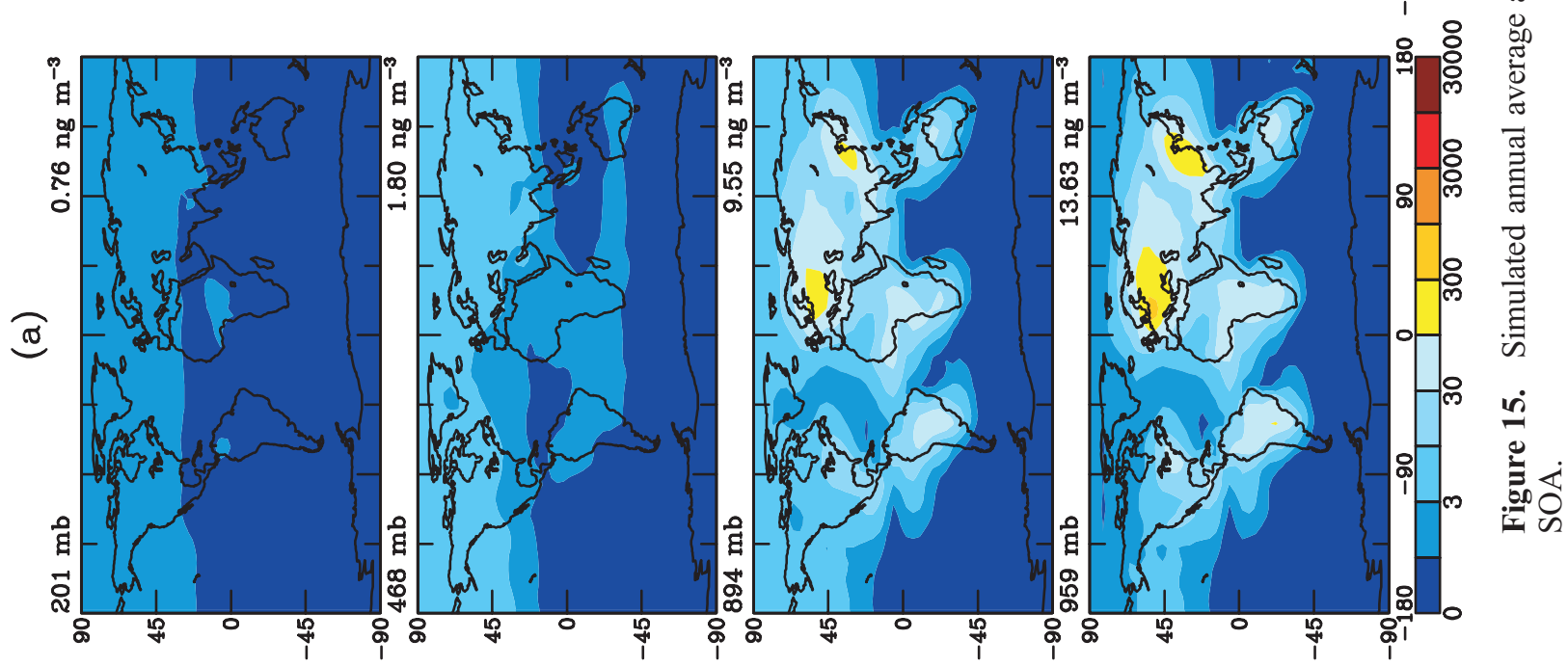
Table 18. Preindustrial and Present-Day Global Burdens of Carbonaceous Aerosols

\begin{tabular}{lcc}
\hline Aerosol & \multicolumn{2}{c}{ Burden $(\mathrm{Tg})$} \\
\cline { 2 - 3 } & Preindustrial & Present-day \\
\hline BC & 0.02 & 0.22 \\
POA & 0.11 & 1.2 \\
SOA & 0.06 & 0.19 \\
\hline
\end{tabular}

Haywood et al., 1997; Myhre et al., 1998; Jacobson, 2000]. To quantify the effect of aerosol mixing state on direct radiative forcing, we consider two limiting cases. In one case, each aerosol component is assumed to be contained in physically separate particles, forming an external mixture. In the other case the aerosols are internally mixed. A more detailed microphysical representation could treat each particle that contains $\mathrm{BC}, \mathrm{OC}$ and sulfate as a core of $\mathrm{BC}$ surrounded by a shell of sulfate, OC and water. As shown by Jacobson [2000], the radiative forcing of aerosols with a concentric core of $\mathrm{BC}$ lies between those of internally and externally mixed particles. By considering the two extreme cases, we can estimate the range of radiative forcing.

\subsection{Aerosol Optical Properties}

[64] Optical properties (extinction efficiency, single-scattering albedo, and asymmetry parameter) of the aerosols are determined by Mie theory based on wavelength-dependent refractive indices and assumed size distributions. The particle size distribution is assumed to be the standard gamma distribution with area-weighted effective variance, $v_{e}=0.2$. We assume that the variance is constant even when particles take up water and grow to larger sizes. The effective dry radius and density, as well as optical properties of dry aerosols at $\lambda=550 \mathrm{~nm}$, of each class are listed in Table 19 . Dry sulfate aerosol is represented as ammonium sulfate, with refractive indices from the work of Toon et al. [1976]. The water uptake of ammonium sulfate aerosol is governed by thermodynamic equilibrium [Adams et al., 1999]. Composite refractive indices of the aqueous sulfate aerosol are the volume-averaged refractive indices of ammonium sulfate and water. Refractive indices of water are taken from the work of d'Almeida et al. [1991]. Refractive indices of soot by d'Almeida et al. [1991] are used for BC. For an internal mixture of $\mathrm{BC}, \mathrm{OC}$, and sulfate aerosols, the refractive indices are calculated by volume-weighting the refractive indices of $\mathrm{BC}, \mathrm{OC},\left(\mathrm{NH}_{4}\right)_{2} \mathrm{SO}_{4}$, and water.

[65] In the absence of data for OC, refractive indices for "water-soluble" aerosol from the work of d'Almeida et al. [1991] are used for OC. "Water-soluble" aerosols as described by d'Almeida et al. [1991] include sulfates, nitrates, as well as water-soluble organic aerosols. Since water uptake by organic aerosol is not well established, we consider two cases. At one limit, we assume no water uptake. In the other case we follow the treatment of water-soluble aerosols given by d'Almeida et al. [1991] (Figure 16). Below $50 \%$ relative humidity, water uptake is assumed to be zero. Above $99 \%$, the growth factor $f_{g}=r_{\text {wet }} / r_{\text {dry }}$ is capped at 2.52. This treatment of water uptake is similar in magnitude to that given by Fitzgerald [1975] and is considered to be the upper bound since not all organic compounds are as soluble as ammonium sulfate. For the case of internally
Table 19. Aerosol Physical and Optical Properties at $\lambda=550 \mathrm{~nm}$ in the Dry State

\begin{tabular}{lccccc}
\hline \multicolumn{1}{c}{ Aerosol type } & $r_{e, \text { dry }}(\mu \mathrm{m})$ & $\rho\left(\mathrm{g} \mathrm{cm}^{-3}\right)$ & $\sigma_{e}\left(\mathrm{~m}^{2} \mathrm{~g}^{-1}\right)$ & $\omega$ & $g$ \\
\hline$\left(\mathrm{NH}_{4}\right)_{2} \mathrm{SO}_{4}$ & 0.3 & 1.8 & 4.2 & 1.00 & 0.69 \\
$\mathrm{OC}$ & 0.5 & 1.8 & 2.53 & 0.94 & 0.68 \\
$\mathrm{BC}$ & 0.1 & 1.0 & 12.5 & 0.38 & 0.47 \\
internal mixture & 0.3 & $\ldots$ & $\ldots$ & $\ldots$ & $\ldots$
\end{tabular}

$r_{e, \text { dry }}=$ effective dry radius; $\rho=$ density; $\sigma_{e}=$ extinction coefficient; $\omega=$ single scattering albedo; $g=$ asymmetry factor.

mixed aerosols, we assume that the total amount of water uptake is equal to that of the externally mixed aerosols.

\subsection{Global Distributions of Direct Radiative Forcing}

[66] The results presented here are 1 year averages after an initial spin up of 7 months. Figure 17 shows the annually averaged global distributions of radiative forcing for anthropogenic sulfate, OC, and $\mathrm{BC}$. The cooling at TOA calculated here for sulfate aerosols is slightly different from that of the work of Adams et al. [2001] because we do not consider the presence of ammonium and nitrate and assume that all sulfate exists as ammonium sulfate. We do, however, include all water that is associated with the equilibrium of $\left(\mathrm{NH}_{4}\right)_{2} \mathrm{SO}_{4}-\mathrm{NO}_{3}-\mathrm{NH}_{4}-\mathrm{H}_{2} \mathrm{O}$ system given by Adams et al. [1999].

[67] The globally averaged annual direct radiative effect of anthropogenic $\mathrm{BC}$ is predicted to be $+0.51 \mathrm{~W} \mathrm{~m}^{-2}$. The effect is predicted to be the greatest in regions of high $\mathrm{BC}$ concentrations and high surface albedo, such as eastern China and northern Europe.

[68] The globally averaged TOA radiative forcing of pure anthropogenic $\mathrm{OC}$ is relatively small, $-0.09 \mathrm{~W} \mathrm{~m}^{-2}$, and the direction of warming or cooling varies geographically based on the surface albedo and cloud cover. The single scattering albedo of OC at $\lambda=550 \mathrm{~nm}$ is $\omega=0.94$ based on the properties given in section 5.2. Over regions of high surface albedo, OC aerosol causes a net warming. For lower albedos, the effect is one of net cooling. In either case, the magnitude

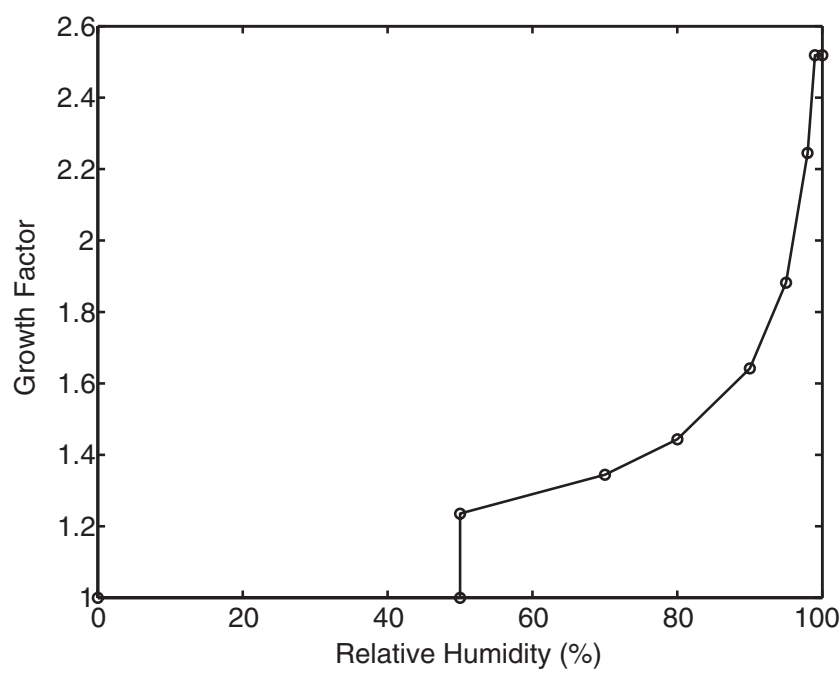

Figure 16. Hygroscopic growth of organic aerosol [d'Almeida et al., 1991]. The growth factor is defined as $f_{g}=r_{\text {wet }} / r_{\text {dry. }}$ 

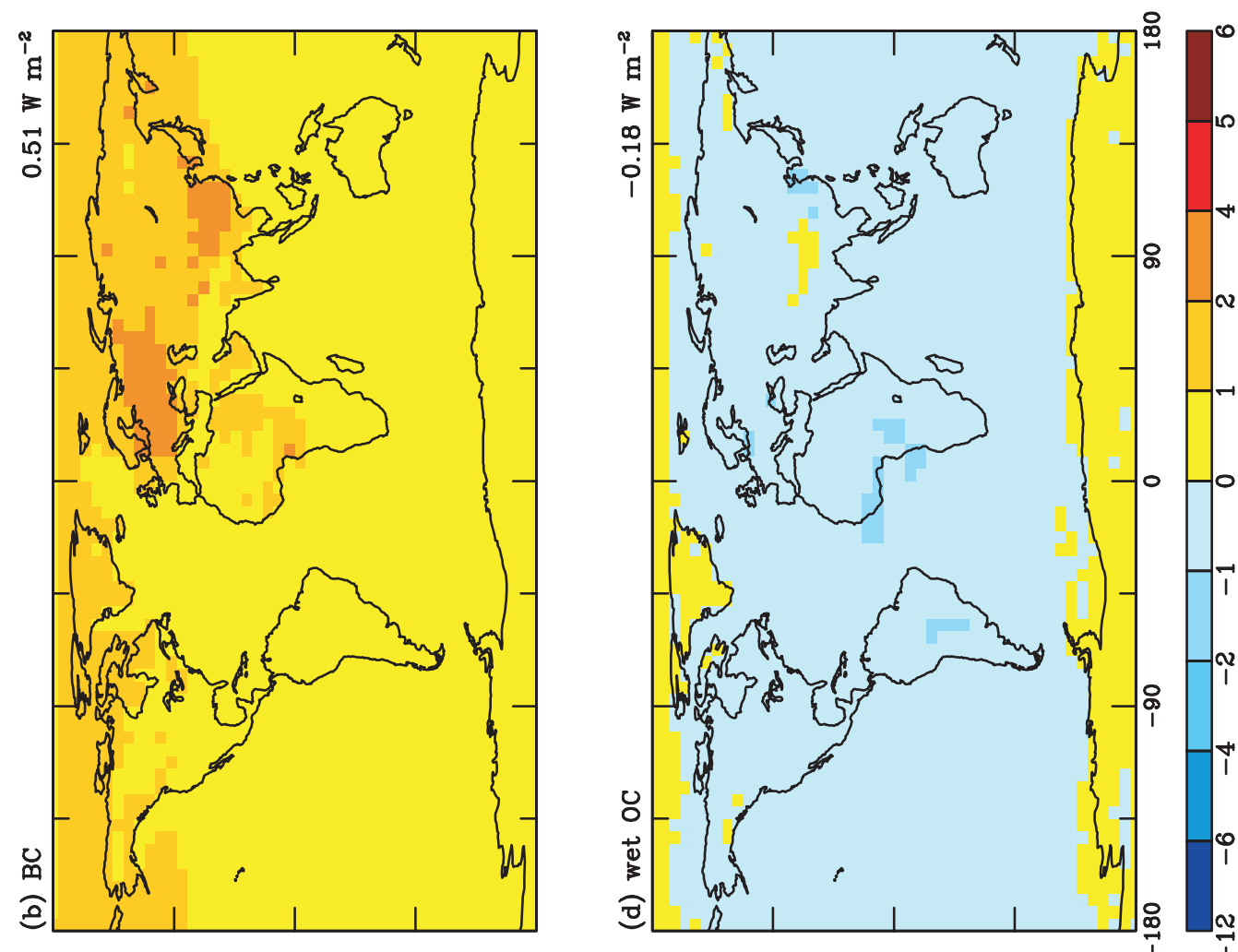

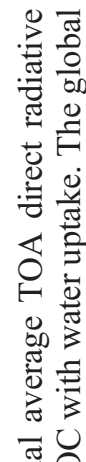
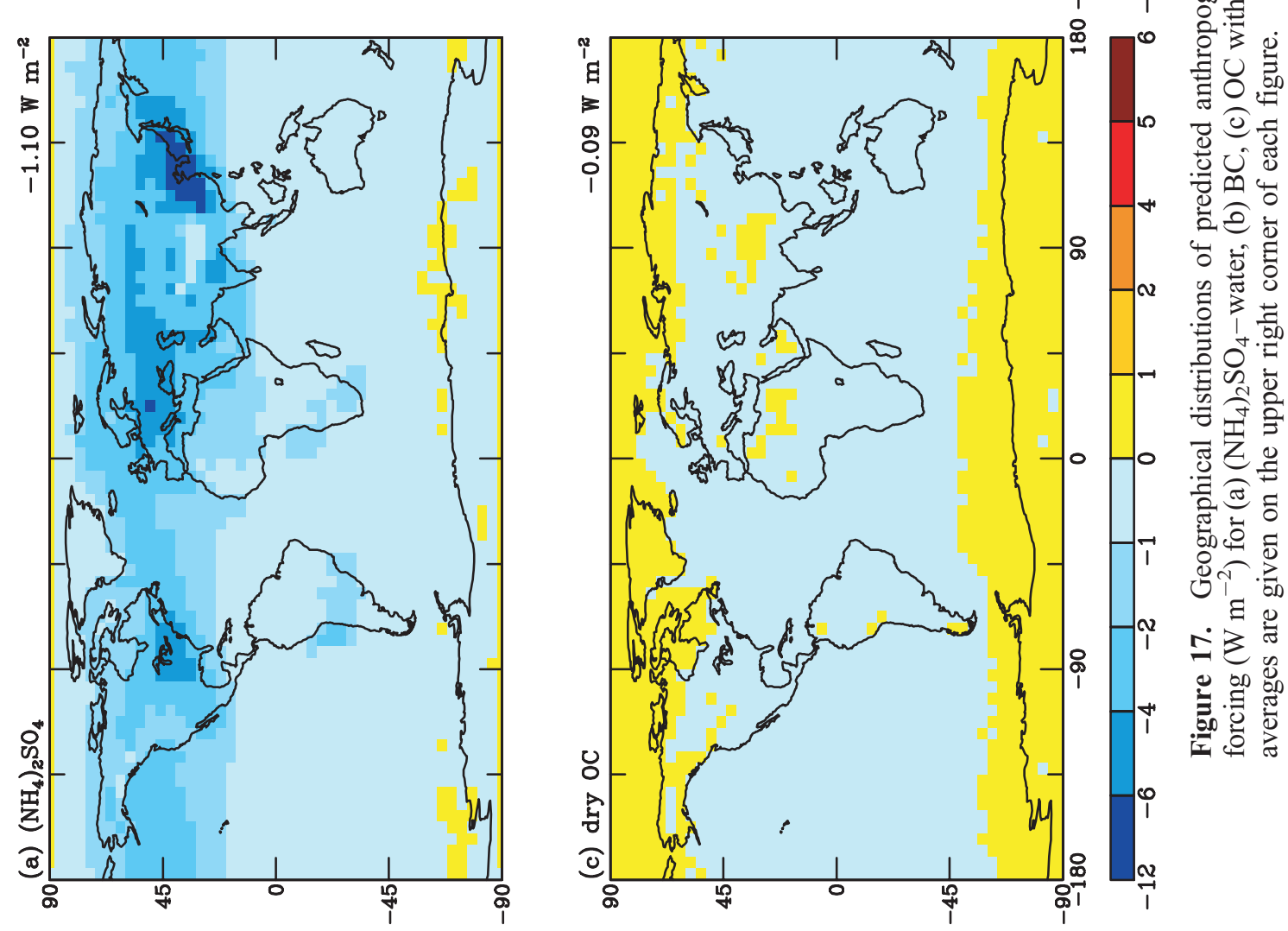

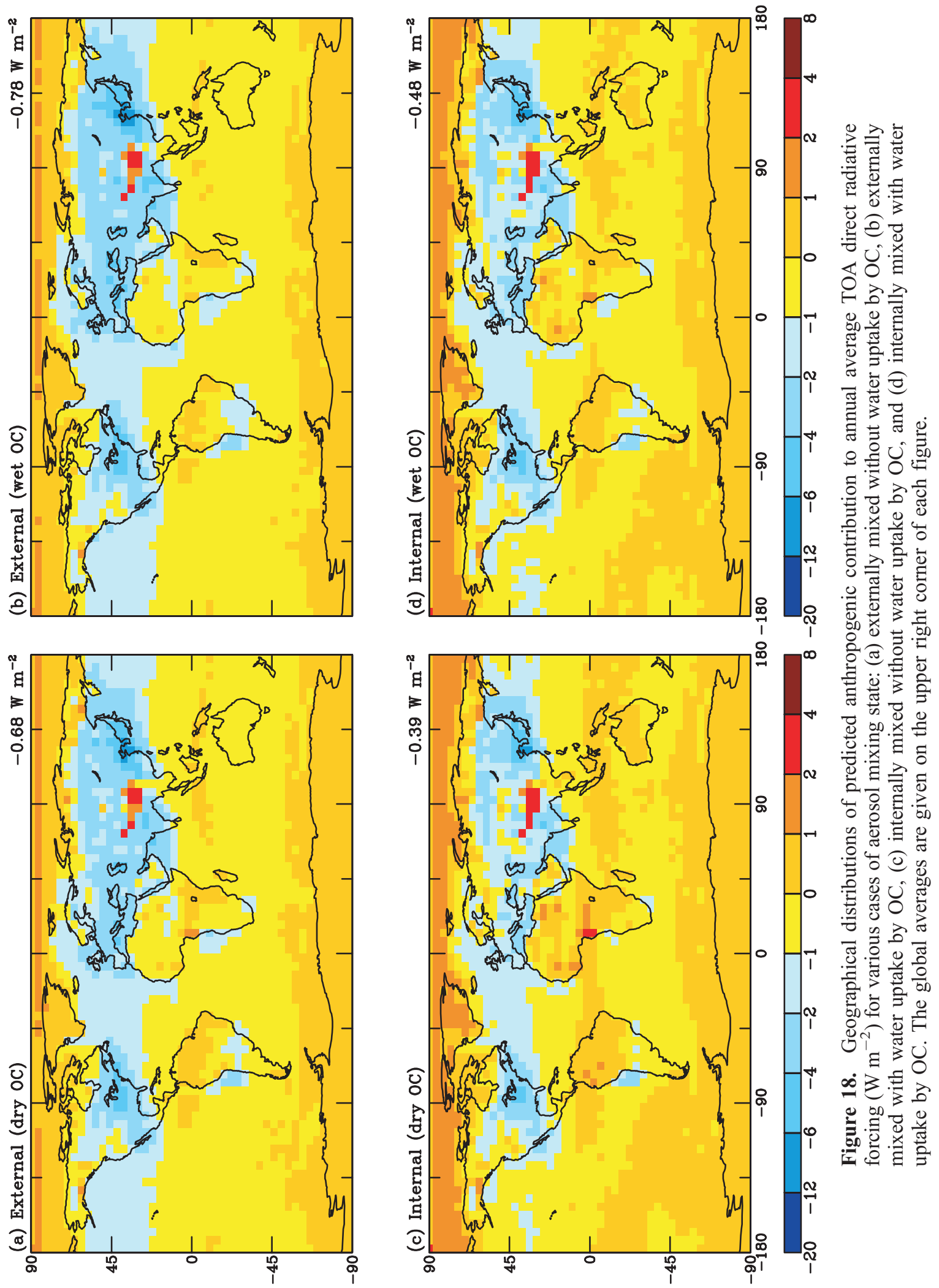
Table 20. Summary of Predicted TOA Direct Radiative Forcing $\left(\mathrm{W} \mathrm{m}^{-2}\right)$

\begin{tabular}{lccc}
\hline \multicolumn{1}{c}{ Aerosol type } & Preindustrial & $\begin{array}{c}\text { Modern } \\
\text { day }\end{array}$ & $\begin{array}{c}\text { Net anthropogenic } \\
\text { forcing }\end{array}$ \\
\hline$\left(\mathrm{NH}_{4}\right)_{2} \mathrm{SO}_{4}$ & -0.53 & -1.63 & -1.10 \\
$\mathrm{BC}$ & 0.07 & 0.57 & 0.51 \\
$\mathrm{OC}$ (dry) & 0.00 & -0.09 & -0.09 \\
$\mathrm{OC}$ (wet) & -0.03 & -0.21 & -0.18 \\
External mixture (dry OC) & -0.47 & -1.15 & -0.68 \\
External mixture (wet OC) & -0.49 & -1.26 & -0.78 \\
Internal mixture (dry OC) & -0.47 & -0.86 & -0.39 \\
Internal mixture (wet OC) & -0.49 & -0.97 & -0.48 \\
\hline
\end{tabular}

of forcing is generally small. Including water uptake by organic aerosol increases the tendency toward cooling (increased $\omega$ ), and the predicted globally averaged annual radiative forcing becomes $-0.18 \mathrm{~W} \mathrm{~m}^{-2}$.

[69] Figure 18 shows the predicted global distributions of TOA radiative forcing for all three types of aerosols combined. As expected, the internally mixed aerosol exhibits less cooling than the external mixture. The predicted cooling decreases from $0.68 \mathrm{~W} \mathrm{~m}^{-2}$ for the external mixture to 0.39 $\mathrm{W} \mathrm{m}{ }^{-2}$ for internally mixed aerosols when water uptake of $\mathrm{OC}$ is not considered. When the water uptake by OC is included, the combined cooling decreases from 0.78 to 0.48 $\mathrm{W} \mathrm{m}^{-2}$. In an internal mixture, $\mathrm{BC}$ is present in every aerosol particle such that all particles absorb radiation; for the external mixture, only BC (and, to a lesser extent, OC) absorbs solar radiation. Even though the overall global net anthropogenic forcing is negative, regions of significant warming are predicted, such as the polar regions, eastern China, and India. Table 20 summarizes the radiative forcing predictions.

\subsection{Seasonal Variations of Direct Radiative Forcing}

[70] The predicted seasonal trend of anthropogenic radiative forcing is shown in Figures 19 and 20. In the NH, the maximum cooling of sulfate occurring in summer coincides with a high $\mathrm{SO}_{2}$ oxidation rate and overlaps with the peak warming of $\mathrm{BC}$, which is dominated by industrial emissions. The BC peak occurs slightly earlier in the $\mathrm{NH}$ because biomass emissions are also important for $\mathrm{BC}$. The peak of $\mathrm{OC}$ in the $\mathrm{NH}$ is determined by a combination of fossil fuel and biomass burning sources. The peak in March represents the tailing part of the biomass burning season but also of increasing fossil fuel sources. Sulfate forcing in the $\mathrm{SH}$ is small in comparison to that in the $\mathrm{NH}$, but still stronger than those of $\mathrm{BC}$ and $\mathrm{OC}$. In the $\mathrm{SH}, \mathrm{OC}$ and $\mathrm{BC}$ forcings peak in August and September, which coincide with peak of the burning season.

[71] Figure 20 shows the combined seasonal effect of all three classes of aerosols. Regardless of the mixing state and water uptake of $\mathrm{OC}$, radiative forcing in the $\mathrm{SH}$ remains relatively constant. Forcing always tends toward cooling except for the case of internally mixed aerosols with no water uptake by OC during the months of June to September. In the $\mathrm{NH}$, there is strong cooling during summer. The presence of $\mathrm{BC}$ reduces the cooling of sulfate and $\mathrm{OC}$ by (a) Sulfate

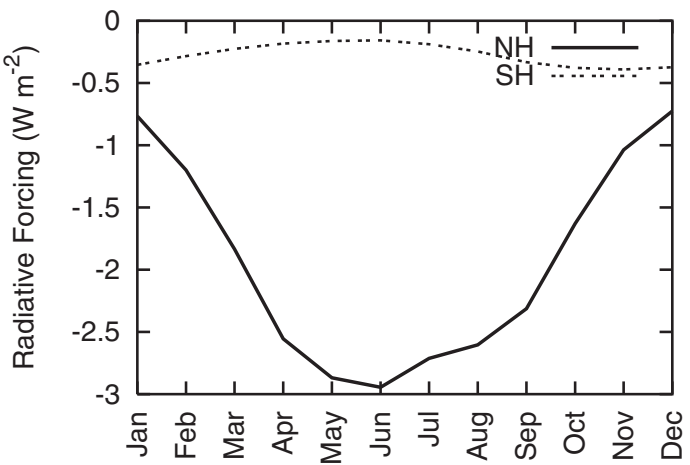

(c) Dry OC

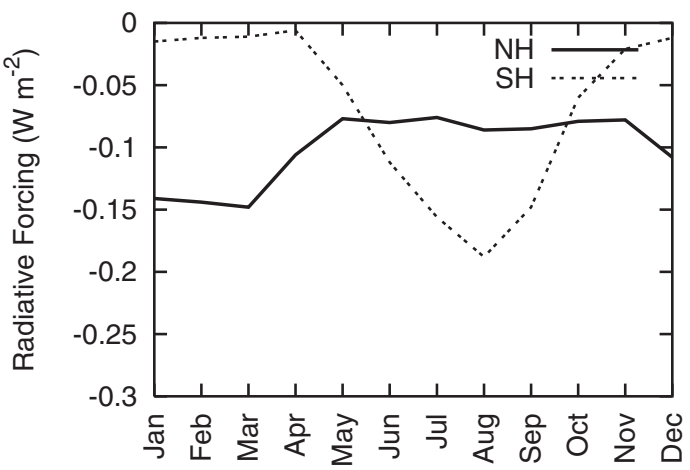

(b) $\mathrm{BC}$

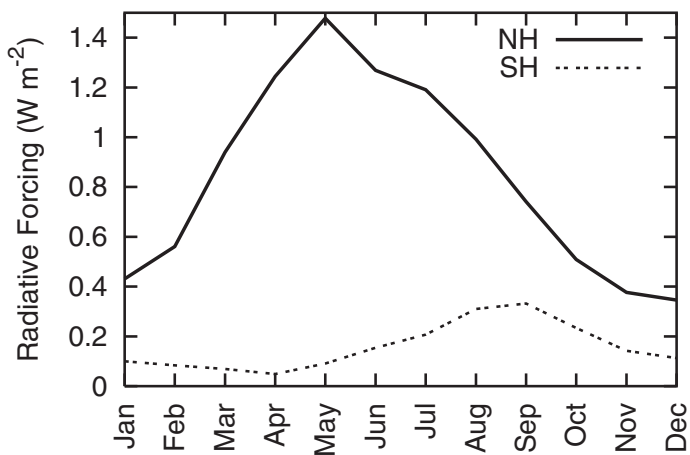

(d) Wet OC

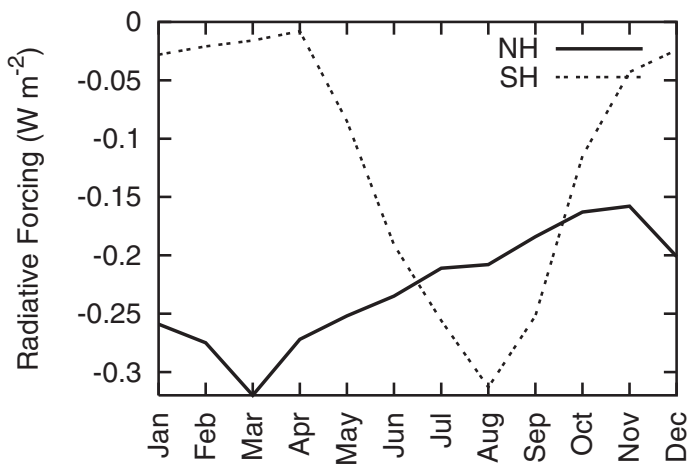

Figure 19. Seasonal cycle of anthropogenic TOA radiative forcing $\left(\mathrm{W} \mathrm{m}^{-2}\right)$ for (a) $\left(\mathrm{NH}_{4}\right)_{2} \mathrm{SO}_{4}-$ water, (b) $\mathrm{BC}$, (c) $\mathrm{OC}$ without water uptake, and (d) $\mathrm{OC}$ with water uptake. 
(a) External (dry OC)

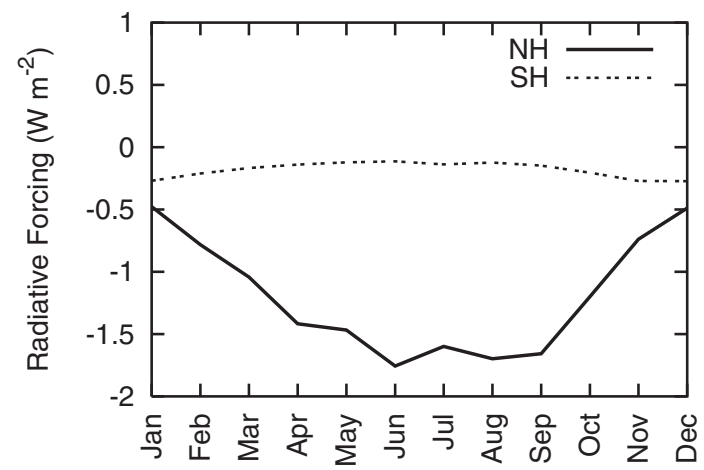

(c) Internal (dry OC)

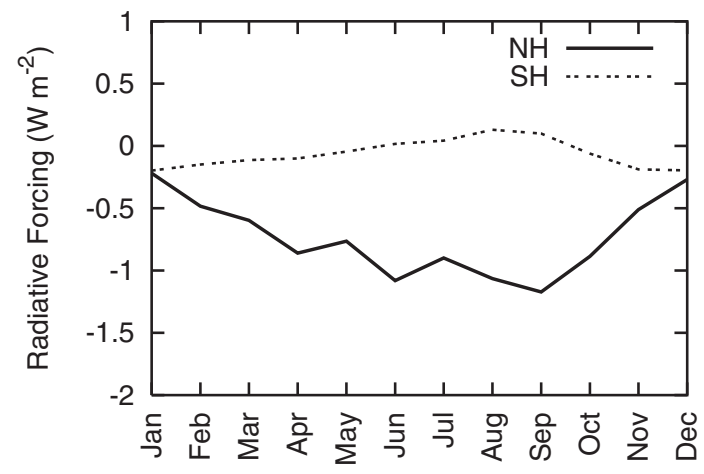

(b) External (wet OC)

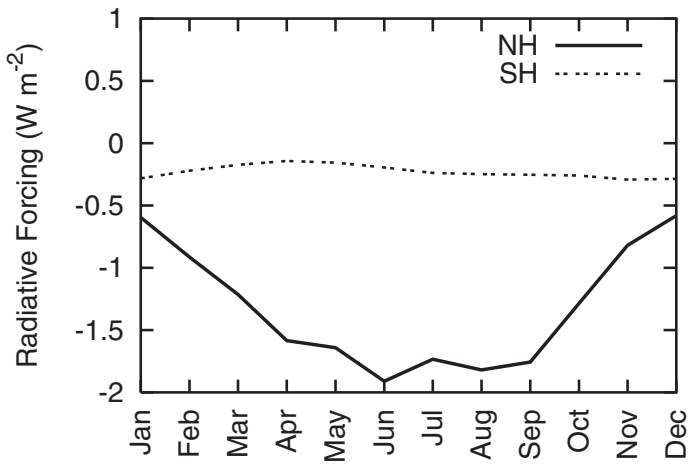

(d) Internal (wet OC)

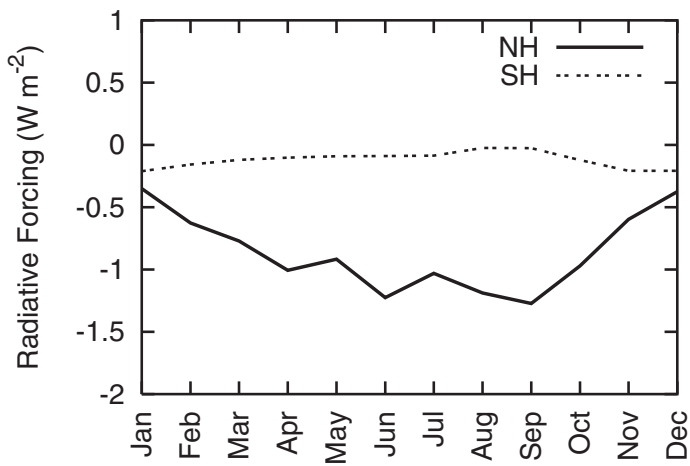

Figure 20. Seasonal cycle of anthropogenic TOA radiative forcing $\left(\mathrm{W} \mathrm{m}^{-2}\right)$ for various cases of aerosol mixing state: (a) externally mixed without water uptake by $\mathrm{OC}$, (b) externally mixed with water uptake by OC, (c) internally mixed without water uptake by OC, and (d) internally mixed with water uptake by OC.

almost one third in case of the internal mixture with dry OC and almost $70 \%$ for an internal mixture with wet OC.

\subsection{Comparison of Predicted Radiative Forcing With Previous Work}

\subsubsection{Black Carbon}

[72] Table 21 compares the predicted direct radiative forcing of BC with those of previous studies. For internally mixed aerosols, separating the contribution of each component to the total radiative forcing is difficult because total radiative forcing is not a linear sum of individual components. For the purpose of comparison with other works, however, we take the direct radiative forcing of $\mathrm{BC}$ in an internal mixture to be the difference in radiative forcing between the internal mixture of sulfate, $\mathrm{OC}$, and $\mathrm{BC}$ and that of an external mixture of sulfate and OC. This definition is still not perfect since most of the studies listed in Table 21 considered only sulfate and BC and excluded OC.

[73] Many of the previous estimated BC radiative forcings listed in Table 21 are relatively small because they considered only fossil fuel $\mathrm{BC}$ and not biomass burning. In Figure 21, predicted $\mathrm{BC}$ radiative forcing is shown as a function of the global $\mathrm{BC}$ burden for the studies in which the global burdens can be determined. Even when differences in global burdens are taken into account, discrepancies among the different studies still exit. Another important factor affecting radiative forcing is the actual three-dimensional distribution, which is different for fossil fuel and biomass burning BC. Haywood and Shine [1995], Haywood et al. [1997], Haywood and Ramaswamy [1998], and Myhre et al. [1998] all assumed that the distribution of fossil $\mathrm{BC}$ scales with that of sulfate. The assumption is oversimplified because not only is the ratio of BC and sulfate emission rates different for varying fuel types, wet scavenging of sulfate is more effective as sulfate is much more soluble. The geographical distribution is important because the radiative forcing is strongly dependent on the surface albedo, the presence of clouds, and the interaction of

Table 21. Comparison of Predicted Direct Radiative Forcing of Black Carbon With Other Studies $\left(\mathrm{W} \mathrm{m}^{-2}\right)$

\begin{tabular}{lccc}
\hline \multicolumn{1}{c}{ Reference } & Emissions & $\begin{array}{c}\text { Mixing } \\
\text { scenario }\end{array}$ & $\begin{array}{c}\text { Anthropogenic } \\
\text { forcing }\end{array}$ \\
\hline This work & FF and BB & External & 0.51 \\
& & Internal & 0.8 \\
Haywood and Shine [1995] & FF & External & 0.04 \\
& & Internal & 0.18 \\
Haywood et al. [1997] & FF & External & 0.20 \\
& & Internal & 0.36 \\
Haywood and Ramaswamy [1998] & FF and BB & External & 0.40 \\
Myhre et al. $[1998]$ & FF & External & 0.16 \\
& & Internal & 0.42 \\
Penner et al. [1998] & FF & External & 0.20 \\
Cooke et al. $[1999]$ & FF & External & 0.17 \\
Jacobson [2000] & FF and BB & External & 0.27 \\
& & Internal & 0.78 \\
Koch [2001] & & BC Core & 0.54 \\
\hline
\end{tabular}

${ }^{\mathrm{a}}$ Clear-sky forcing.

$\mathrm{FF}=$ fossil fuel; $\mathrm{BB}=$ biomass burning. 


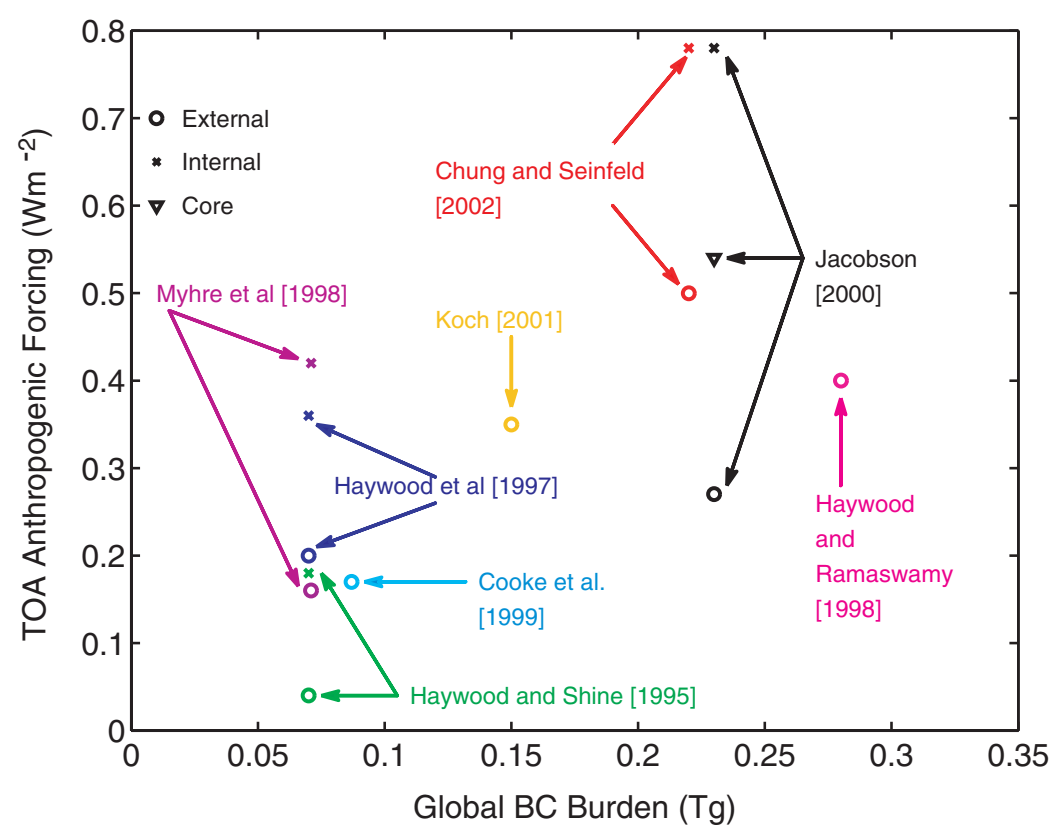

Figure 21. Comparison of $\mathrm{BC}$ radiative forcing predictions versus $\mathrm{BC}$ global burden by various authors. The color of the data points is coded to the authors, and their shapes correspond to the assumptions made about the mixing state of the aerosols.

scattering and absorbing aerosols in the case of an internal mixture [Haywood et al., 1997; Haywood and Ramaswamy, 1998]. Finally, uncertainties in the size distribution of the aerosols lead to variabilities in the predictions.

\subsubsection{Organic Carbon}

[74] Radiative forcing of organic aerosol has been less studied than BC. Cooke et al. [1999] calculated the radiative forcing of fossil OC to be $-70 \mathrm{~W} \mathrm{~g} \mathrm{C}^{-1}\left(-0.012 \mathrm{~W} \mathrm{~m}^{-2}\right.$ and $0.087 \mathrm{Tg} \mathrm{C}$ ) and Koch [2001] calculated the forcing of fossil fuel and biomass $\mathrm{OC}$ to be $-210 \mathrm{~W} \mathrm{~g} \mathrm{C}^{-1}\left(-0.30 \mathrm{~W} \mathrm{~m}^{-2}\right.$ and $0.95 \mathrm{Tg} \approx 0.73 \mathrm{Tg} \mathrm{C}$ ). Our values of -36 to $-76 \mathrm{Wg}$ $\mathrm{OC}^{-1}\left(-0.08\right.$ to $-0.17 \mathrm{~W} \mathrm{~m}^{-2}$ and $\left.1.48 \mathrm{Tg} \approx 1.14 \mathrm{Tg} \mathrm{C}\right)$ are comparable to those of the work of Cooke et al. [1999]. The major difference between our work and that of Koch [2001] lies in the optical properties of OC. At $\lambda=550 \mathrm{~nm}$, we used an extinction coefficient $\sigma_{e}=2.53 \mathrm{~m}^{2} \mathrm{~g}^{-1}$, whereas Koch [2001] used $\sigma_{e}=8 \mathrm{~m}^{2} \mathrm{~g}^{-1}$ for dry OC, the refractive indices of ammonium sulfate for OC instead of the "water-soluble" aerosol that Cooke et al. [1999] and the present study employ. The optical properties also depend on water uptake by the OC. Both Cooke et al. [1999] and Koch [2001] considered only dry OC.

\section{Conclusions}

[75] The global distribution of carbonaceous aerosols is simulated online in the GISS GCM II-prime. We include $\mathrm{BC}$ and POAs from fossil fuel and biomass burning, as well as SOAs from the oxidation of biogenic hydrocarbons. Simulated BC concentrations are generally low at rural and marine sites when compared with available measurements. In comparison to $\mathrm{BC}$ and $\mathrm{OC}$ concentrations measured at rural sites in the United States, predictions are consistently low, suggesting that the carbonaceous aerosol emissions inventory in the U.S. might be too low. Overall, the results suggest that wet scavenging, the dominant sink for carbonaceous aerosols, may be overestimated. More accurate predictions of scavenging require better knowledge of the hydrophilic fraction of primary aerosols and the solubility of hydrophilic aerosols.

[76] We also present global simulation of SOA from oxidation of biogenic hydrocarbons by $\mathrm{O}_{3}, \mathrm{OH}$, and $\mathrm{NO}_{3}$. Unlike POAs, which have the highest concentrations at the surface near source regions, SOA is predicted to accumulate in cold regions of the upper troposphere. At the surface, SOA contributes only about 10 to $20 \%$ of the total OC, whereas in polar regions it is predicted to contribute up to $50 \%$. The reason is that semivolatile gas-phase oxidation products are transported to higher altitudes where colder temperatures allow more products to condense. SOA burden and lifetime are sensitive to the temperature dependence of gas-particle partition coefficients. SOA production is also sensitive to the solubility of the gas-phase oxidation products since solubility determines how effectively they are removed from the atmosphere by wet scavenging and how far they are transported away from their source regions.

[77] Human activities since the preindustrial period are predicted to have increased global burdens of $\mathrm{BC}$ and $\mathrm{OC}$ by an order of magnitude and almost tripled the SOA production rate. Anthropogenic perturbations are especially pronounced in the $\mathrm{NH}$ due to fossil fuel use.

[78] Anthropogenic $\mathrm{BC}$ is predicted to contribute to a globally and annually averaged net radiative forcing of $+0.51 \mathrm{~W} \mathrm{~m}^{-2}$ when considered to be externally mixed and $+0.78 \mathrm{~W} \mathrm{~m}^{-2}$ when occurring in an internal mixture of $\mathrm{BC}$, $\mathrm{OC}$, and sulfate. Externally mixed $\mathrm{OC}$ has a radiative forcing of -0.09 to $-0.17 \mathrm{~W} \mathrm{~m}^{-2}$, depending on the amount of water uptake. Globally averaged and taken together, anthropogenic $\mathrm{BC}, \mathrm{OC}$ and sulfate are predicted to exert a radiative forcing of -0.4 to $-0.76 \mathrm{~W} \mathrm{~m}^{-2}$, depending on the exact 
assumptions of aerosol mixing and water uptake by OC. Even though the net radiative effect is one of cooling, warming of up to $3 \mathrm{~W} \mathrm{~m}^{-2}$ is predicted to occur in regions of large $\mathrm{BC}$ concentrations and high surface albedo. The annual combined cycle of $\mathrm{BC}, \mathrm{OC}$, and sulfate radiative forcing is nearly constant in the SH but varies strongly with season in the $\mathrm{NH}$, with maximum cooling occurring during summer. Regional climate perturbations are expected to lead to climate feedback that warrant further study.

[79] Acknowledgments. This work was supported by the National Aeronautics and Space Administration Earth Observing System Interdisciplinary Science Program (NASA EOS-IDS). Serena Chung was supported by a National Science Foundation Graduate Fellowship. The authors thank Peter Adams and Dorothy Koch for assistance.

\section{References}

Adams, P. J., J. H. Seinfeld, and D. M. Koch, Global concentrations of tropospheric sulfate, nitrate, and ammonium aerosol simulated in a general circulation model, J. Geophys. Res., 104, 13,791-13,823, 1999.

Adams, P. J., J. H. Seinfeld, D. M. Koch, L. Mickley, and D. Jacob, General circulation model assessment of direct radiative forcing by sulfate-nitrate-ammonium-water inorganic aerosol system, J. Geophys. Res., 106, 2001.

Andersson-Sköld, Y., and D. Simpson, Secondary organic aerosol formation in northern Europe: A model study, J. Geophys. Res., 106, $7357-$ 7374, 2001

Andreae, M. O., T. W. Andreae, R. J. Ferek, and H. Raemdonck, Longrange transport of soot carbon in the marine atmosphere, Sci. Total Environ., 36, 73-80, 1984 .

Atkinson, R., Gas-phase tropospheric chemistry of organic compounds, J. Phys. Chem. Ref. Data, Monogr., 2, 1994.

Atkinson, R., Gas-phase tropospheric chemistry of volatile organic compounds, 1, Alkanes and alkenes, J. Phys. Chem. Ref. Data, 26, 215-290, 1997.

Atkinson, R., J. Arey, S. M. Aschmann, S. B. Corchnoy, and Y. Shu, Rate constants for the gas-phase reactions of cis-3-hexen-1-ol, cis-3-hexenylacetate, trans-2-hexenal, and linalool with $\mathrm{OH}$ and $\mathrm{NO}_{3}$ radicals and $\mathrm{O}_{3}$ at $296 \pm 2 \mathrm{~K}$ and $\mathrm{OH}$ radical formation yields from the $\mathrm{O}_{3}$ reactions, Int. J. Chem. Kinet., 27, 941-955, 1995.

Bahrmann, C. P., and V. K. Saxena, Influence of air mass history on black carbon concentrations and regional climate forcing in southeastern United States, J. Geophys. Res., 103, 23,153-23,161, 1998.

Baltensperger, U., H. W. Gäggeler, D. T. Jost, M. Lugauer, M. Schwikowski, and E. Weingartner, Aerosol climatology at the high-Alpine site Jungfraujoch, Switzerland, J. Geophys. Res., 102, 19,707-19,715, 1997.

Barth, M. C., P. J. Rasch, J. T. Kiehl, C. M. Benkovitz, and S. E. Schwartz, Sulfur chemistry in the National Center for Atmospheric Research Community Climate Model: Description, evaluation, features, and sensitivity to aqueous chemistry, J. Geophys. Res., 105, 1387-1415, 2000.

Benkovitz, C. M., C. M. Berkowitz, R. C. Easter, S. Memesure, R. Wagner, and S. E. Schwartz, Sulfate over the North Atlantic and adjacent continental regions: Evaluation for October and November 1986 using a three-dimensional model driven by observation-derived meteorology, J. Geophys. Res., 99, 20,725-20,756, 1994.

Berner, A., S. Sidla, Z. Galambos, C. Kruisz, and R. Hitzenberger, Modal character of atmospheric black carbon size distributions, J. Geophys. Res., 101, 19,559-19,565, 1996.

Bizjak, M., J. Tursic, M. Lesnjak, and T. Cegnar, Aerosol black carbon and ozone measurements at Mt. Krvavec EMEP GAW station, Slovenia, Atmos. Environ., 33, 2783-2787, 1999.

Bodhaine, B. A., Aerosol absorption measurements at Barrow, Mauna-Loa and the South-Pole, J. Geophys. Res., 100, 8967-8975, 1995.

Bond, T. C., Light absorption by primary particles from fossil-fuel combustion: Implication for radiative forcing, Ph.D. thesis, Univ. of Wash. Seattle, Wash. 98195, 2000.

Cachier, H., M. P. Brémond, and P. Buat-Ménard, Determination of atmospheric soot carbon with a simple thermal method, Tellus, 41B, 379-390, 1989.

Cachier, H., M. P. Brémond, and P. Buat-Ménard, Organic and black carbon aerosols over marine regions of the northern hemisphere, in Proceedings of the International Conference on Global and Regional Environmental Atmospheric Chemistry, edited by L. Newman et al., pp. 249-261, Dept. of Energy, Brookhaven Natl. Lab., Upton, N. Y., 1990.

Cadle, S. H., and J. M. Dasch, Wintertime concentrations and sinks of atmospheric particulate carbon at a rural location in northern Michigan, Atmos. Environ., 22, 1373-1381, 1988

Calogirou, A., B. R. Larsen, and D. Kotzias, Gas-phase terpene oxidation products: A review, Atmos. Environ., 33, 1423-1439, 1999.

Castro, L. M., C. A. Pio, R. M. Harrison, and D. J. T. Smith, Carbonaceous aerosol in urban and rural European atmospheres: Estimation of secondary organic carbon concentrations, Atmos. Environ., 33, 2771-2781, 1999.

Charlson, R. J., J. Langner, H. Rodhe, C. B. Leovy, and S. G. Warren, Perturbation of the Northern Hemisphere radiative balance by backscattering from anthropogenic sulfate aerosols, Tellus, 43AB, 152-163, 1991.

Chesselet, R., M. Fontugne, P. Buat-Ménard, U. Ezat, and C. E. Lambert, The origin of particulate organic carbon in the marine atmosphere as indicated by its stable carbon isotopic composition, Geophys. Res. Lett., 8, 345-348, 1981 .

Chin, M., D. J. Jacob, G. M. Gardner, M. S. Foreman-Fowler, and P. A. Spiro, A global three-dimensional model of tropospheric sulfate, J. Geophys. Res., 101, 18,667-18,690, 1996.

Chow, J. C., J. G. Watson, E. M. Fujita, Z. Q. Lu, D. R. Lawson, and L. L. Ashbaugh, Temporal and spatial variations of $\mathrm{PM}_{2.5}$ and $\mathrm{PM}_{10}$ aerosol in the Southern California Air-Quality Study, Atmos. Environ., 28, $2061-$ 2080, 1994

Chuang, C. C., J. E. Penner, K. E. Taylor, A. S. Grossman, and J. J. Walton, An assessment of the radiative effects of anthropogenic sulfate, J. Geophys. Res., 102, 3761-3778, 1997.

Chyýlek, P., G. Videen, D. Ngo, R. G. Pinnick, and J. D. Klett, Effect of black carbon on the optical properties and climate forcing of sulfate aerosols, J. Geophys. Res., 100, 16,325-16,332, 1995.

Chýlek, P., L. Kou, B. Johnson, F. Boudala, and G. Lesins, Black carbon concentrations in precipitation and near surface air in and near Halifax, Nova Scotia, Atmos. Environ., 33, 2269-2277, 1999

Cooke, W. F., and J. J. N. Wilson, A global black carbon aerosol model, J. Geophys Res., 101, 19,395-19,409, 1996.

Cooke, W. F., S. G. Jennings, and T. G. Spain, Black carbon measurements at Mace Head, 1989-1996, J. Geophys. Res., 102, 25,339-25,346, 1997.

Cooke, W. F., C. Liousse, H. Cachier, and J. Feichter, Construction of a $1^{\circ} \times 1^{\circ}$ fossil fuel emission data set for carbonaceous aerosol and implementation and radiative impact in the ECHAM4 model, J. Geophys. Res. 104, 22,137-22,162, 1999.

d'Almeida, G. A., P. Koepke, and E. P. Shettle, Atmospheric Aerosol: Global Climatology and Radiative Characteristics, A. Deepak, Hampton, Va., 1991.

Darzi, M., and J. W. Winchester, Aerosol characteristics at Mauna Loa Observatory, Hawaii, after east Asian dust storm episodes, J. Geophys. Res. 87, 1251-1258, 1982

Davidson, C. I., S. Lin, and J. F. Osborn, Indoor and outdoor air pollution in the Himalayas, Environ. Sci. Technol., 20, 561-567, 1986.

Del Genio, A. D. and Y. Yao, Efficient cumulus parameterization for longterm climate studies: The GISS scheme, in The Representation of Cumulus Convection in Numerical Models Monograph 46, edited by K. E. Emanuel and D. J. Raymond, pp. 181-184, Am. Meteorol. Soc., Boston, Mass., 1993.

Del Genio, A. D., M.-S. Yao, W. Kavari, and K. K.-W. Lo, A prognostic cloud water parameterization for global climate models, J. Clim., 9, 270304, 1996

Dzubay, T. G., R. K. Stevens, and P. L. Haagenson, Composition and origins of aerosol at a forested mountain in Soviet Georgia, Environ. Sci. Technol., 18, 873-883, 1984.

Falk, A., E. Gullstrand, A. Löf, and E. Wigaeus-Hjelm, Liquid/air partition coefficients of four terpenes, Br. J. Ind. Med., 47, 62-64, 1990.

Feichter, J., E. Kjellstrom, H. Rodhe, F. Dentener, J. Lelieveld, and G. J. Roelofs, Simulation of the tropospheric sulfur cycle in a global climate model, Atmos. Environ., 30, 1693-1707, 1996.

Feichter, J., U. Lohmann, and I. Schult, The atmospheric sulfur cycle in ECHAM-4 and its impact on the shortwave radiation, Clim. Dyn., 13, 235-246, 1997.

Fitzgerald, J. W., Approximation formulas for the equilibrium size of an aerosol as a function of its dry size and composition and the ambient relative humidity, J. Appl. Meteorol., 14, 1044-1049, 1975.

Griffin, R. J., D. Dabdub, D. R. C. III, and J. H. Seinfeld, Estimate of global atmospheric organic aerosol from oxidation of biogenic hydrocarbons, Geophys. Res. Lett., 26, 2721-2724, 1999a.

Griffin, R. J., D. R. C. III, R. C. Flagan, and J. H. Seinfeld, Organic aerosol formation from the oxidation of biogenic hydrocarbons, J. Geophys. Res., 104, 3555-3567, 1999b.

Guenther, A., et al., A global model of natural volatile organic compound emissions, J. Geophys. Res., 100, 8873-8892, 1995.

Hansen, A. D. A., H. Rosen, and T. Novakov, Real-time measurement of the absorption coefficient of aerosol particles, Appl. Opt., 21, 30603062, 1982. 
Hansen, J., G. Russell, D. R. P. Stone, A. Lacis, S. Lebedeff, R. Ruedy, and L. Travis, Efficient three-dimensional global models for climate studies: Model I and II, Mon. Weather Rev., 111, 609-662, 1983.

Hansen, A. D. A., V. N. Kapustin, and A. D. Polissar, Measurements of airborne carbonaceous aerosols in the eastern Arctic, Izv. Acad. Sci. USSR, Atmos. Ocean. Phys. Engl. Transl., 27, 429-433, 1991

Harris, J. M., and J. D. Kahl, A descriptive atmospheric transport climatology of the Mauna Loa Observatory, using clustered trajectories, J. Geophys. Res., 95, 13,651-13,667, 1990.

Hartke, G. J., and D. Rind, Improved surface and boundary layer models for the Goddard Institute for Space Studies general circulation model, J. Geophys. Res., 102, 16,407-16,422, 1997

Haywood, J. M., and V. Ramaswamy, Global activity studies of the direct forcing due to anthropogenic sulfate and black carbon aerosols, J. Geophys. Res., 103, 6043-6058, 1998

Haywood, J. M., and K. P. Shine, The effect of anthropogenic sulfate and soot aerosol on the clear sky planetary radiation budget, Geophys. Res. Lett., 22, 603-605, 1995.

Haywood, J. M., D. L. Roberts, A. Slingo, J. M. Edwards, and K. P. Shine, General circulation model calculations of the direct radiative forcing by anthropogenic sulfate and fossil-fuel soot aerosol, J. Clim., 10, $1562-$ 1577,1997

Heintzenberg, J., Size-segregated measurements of particulate elemental carbon and aerosol light-absorption at remote Arctic locations, Atmos. Environ., 16, 2461-2469, 1982.

Heintzenberg, J., and E. K. Bigg, Tropospheric transport of trace substances in the Southern Hemisphere, Tellus, 42B, 355-363, 1990.

Heintzenberg, J., and C. Leck, Seasonal variation of the atmospheric aerosol near the top of the marine boundary layer over Spitzenberg related to the Arctic sulfur cycle, Tellus, 46B, 52-67, 1994.

Heintzenberg, J., and A. Mészáros, Elemental carbon, sulfur and metals in aerosol samples at a Hungarian regional air pollution station, Idöjárás, $89,313-319,1985$

Heintzenberg, J., K. Müller, W. Birmili, G. Spindler, and A. Wiedensohler, Mass-related aerosol properties over the Leipzig basin, J. Geophys. Res. $103,13,125-13,135,1998$

Hitzenberger, R., A. Berner, H. Giebl, R. Koch, S. M. Larson, A. Rouc, A Koch, S. Marischka, and H. Puxbaum, Contribution of carbonaceous material to cloud condensation nuclei concentrations in European background (Mt. Sonnblick) and urban (Vienna) aerosols, Atmos. Environ. 33, 2647-2659, 1999.

Hoffman, E. J., and R. A. Duce, The organic carbon content of marine aerosols collected on Bermuda, J. Geophys. Res., 79, 4474-4477, 1974

Hoffman, E. J., and R. A. Duce, Organic carbon in marine atmospheric particulate matter: Concentration and particle size distribution, Geophys. Res. Lett., 4, 449-452, 1977.

Hoffmann, T., J. R. Odum, F. Bowman, D. Collins, D. Klockow, R. C Flagan, and J. H. Seinfeld, Formation of organic aerosols from the oxidation of biogenic hydrocarbons, J. Atmos. Chem., 26, 189-222, 1997.

Hopper, J. F., D. E. J. Worthy, L. A. Barrie, and N. B. A. Trivett, Atmospheric observations of aerosol black carbon, carbon-dioxide, and methane in the high Arctic, Atmos. Environ., 28, 3047-3054, 1994.

Houghton, J. T., Y. Ding, D. J. Griggs, M. Noguer, P. J. van der Linden, D Xiaosu, K. Maskell, and C. A. Johnson (Eds.), Intergovernmental Panel on Climate Change (IPCC): Climate Change, 2001, Cambridge Univ. Press, New York, 2001

Jacobson, M. Z., A physically-based treatment of elemental carbon optics: Implication for global direct forcing of aerosols, Geophys. Res. Lett., 27 , 217-220, 2000

Jacobson, M. Z., Strong radiative heating due to the mixing state of black carbon in atmospheric aerosols, Nature, 409, 695-697, 2001a

Jacobson, M. Z., Global direct radiative forcing due to multicomponent anthropogenic and natural aerosols, J. Geophys. Res., 196, 1551-1568, $2001 b$.

Janssen, N. A. H., D. F. M. VanMansom, K. VanDerJagt, H. Harssema, and G. Hoek, Mass concentration and elemental composition of airborne particulate matter at street and background locations, Atmos. Environ., 31, 1185-1193, 1997.

Japar, S. M., W. W. Brachaczek, R. A. B. Jr., J. M. Norbeck, and W. R. Pierson, The contribution of elemental carbon to the optical properties of rural atmospheric aerosols, Atmos. Environ., 20, 1281-1289, 1986.

Kamens, R., M. Jang, C. Chien, and K. Leach, Aerosol formation from the reaction of $\alpha$-pinene and ozone using a gas-phase kinetics-aerosol partitioning model, Environ. Sci. Technol., 33, 1430-1438, 1999.

Kanakidou, M., K. Tsigaridis, F. J. Dentener, and P. J. Crutzen, Humanactivity-enhanced formation of organic aerosols by biogenic hydrocarbon oxidation, J. Geophys. Res., 105, 9243-9254, 2000.

Kaneyasu, N., and S. Murayama, High concentrations of black carbon over middle latitudes in the North Pacific Ocean, J. Geophys. Res., 105 $19,881-19,890,2000$.
Kiehl, J. T., and B. P. Briegleb, The relative roles of sulfate aerosols and greenhouse gases in climate forcing, Science, 260, 311-314, 1993

Kiehl, J. T., T. L. Schneider, P. J. Rasch, M. C. Barth, and J. Wong, Radiative forcing due to sulfate aerosols from simulations with the $\mathrm{Na}$ tional Center for Atmospheric Research Community Climate Model, Version 3, J. Geophys. Res., 105, 1441-1457, 2000.

Kim, Y. P. K. C. Moon, J. H. Lee, and N. J. Baik, Concentrations of carbonaceous species in particles at Seoul and Cheju in Korea, Atmos. Environ., 33, 2751-2758, 1999

Kim, Y. P., K. C. Moon, and J. H. Lee, Organic and elemental carbon in fine particles at Kosan, Korea, Atmos. Environ., 34, 3309-3317, 2000.

Koch, D., The transport and direct radiative forcing of carbonaceous and sulfate aerosols in the GISS GCM, J. Geophys. Res., 106, 20,31120,332, 2001

Koch, D., D. Jacob, I. Tegen, D. Rind, and M. Chin, Tropospheric sulfur simulation and sulfate direct radiative forcing in the Goddard Institute for Space Studies general circulation model, J. Geophys. Res., 104, 23,799$23,822,1999$

Lacis, A. A., and J. E. Hansen, A parameterization for the absorption of solar radiation in the earth's atmosphere, J. Aerosol Sci., 31, 118-133, 1974.

Lacis, A. A. and M. I. Mishchenko, Climate forcing, climate sensitivity, and climate response: A radiative modeling perspective on atmospheric aerosols, in Aerosol Forcing of Climate, edited by R. J. Charlson and J. Heintzenberg, pp. 11-42, John Wiley, New York, 1995.

Lacis, A. A., and V. Oinas, A description of the correlated $k$-distribution method for modeling nongray gaseous absorption, thermal emission, and multiple-scattering in vertically inhomogeneous atmospheres, J. Geophys. Res., 96, 9027-9063, 1991

Langner, J., and H. Rodhe, A global three-dimensional model of the tropospheric sulfur cycle, J. Aerosol Sci., 13, 225-263, 1991.

Lavanchy, V. M. H., H. W. Gaggeler, S. Nyeki, and U. Baltensperger, Elemental carbon (EC) and black carbon (BC) measurements with a thermal method and an aethalometer at the high-alpine research station Jungfraujoch, Atmos. Environ., 33, 2759-2769, 1999.

Lavoué, D., C. Liousse, H. Cachier, B. J. Stocks, and J. G. Goldammer, Modeling of carbonaceous particles emitted by boreal and temperate wildfires at northern latitudes, J. Geophys. Res., 105, 26,871-26,890, 2000

Li, J., E. M. Perdue, S. G. Pavlostathis, and R. Araujo, Physicochemical properties of selected monoterpenes, Environ. Int., 24, 353-358, 1998.

Lide, D. R., (Ed.), CRC Handbook of Chemistry and Physics, CRC Press, Boca Raton, Fla., 2001.

Limbeck, A., and H. Puxbaum, Dependence of in-cloud scavenging of polar organic aerosol compounds on the water solubility, J. Geophys. Res., 105, 19,857-19,867, 2000 .

Lindberg, J. D., R. E. Douglass, and D. M. Garvey, Atmospheric particulate absorption and black carbon measurement, Appl. Opt., 38, 2369-2376, 1999.

Liousse, C., H. Cachier, and S. G. Jennings, Optical and thermal measurements of black carbon aerosol content in different environments: Variation of specific attenuation cross-section, sigma $(\sigma)$, Atmos. Environ., 27, $1203-1211,1993$

Liousse, C., J. E. Penner, C. Chuang, J. J. Walton, H. Eddleman, and H. Cachier, A global three-dimensional model study of carbonaceous aerosols, J. Geophys. Res., 101, 19,411-19,432, 1996.

Loew, J. A., M. H. Smith, B. M. Davison, S. E. Benson, M. K. Hill, C. D. O'Dowd, R. M. Harrison, and C. N. Hewitt, Physicochemical properties of atmospheric aerosol at South Uist, Atmos. Environ., 30, 3765-3776, 1996.

Lohmann, U., K. von Salzen, N. McFarlane, H. G. Leighton, and J. Feichter, Tropospheric sulfur cycle in the Canadian general circulation model, J. Geophys. Res., 104, 26,833-26,858, 1999.

Luecken, D. J., C. M. Berkowitz, and R. C. Easter, Use of a three-dimensional cloud-chemistry model to study the trans-Atlantic transport of soluble sulfur species, J. Geophys. Res., 96, 22,477-22,490, 1991

Lugauer, M., U. Baltensperger, M. Furger, H. W. Gäggeler, D. T. Jost, M. Schwikowski, and H. Wanner, Aerosol transport to the high Alpine sites Jungfraujoch (3454 m asl) and Colle Gnifetti (4452 $\mathrm{m}$ asl), Tellus, 50B, 76-92, 1998

Malm, W. C., M. L. Pitchford, M. Scruggs, J. F. Sisler, R. Ames, S. Copeland, K. A. Gebhart, and D. E. Day, Spational and Seasonal Patterns and Temporal Variability of Haze and Its Constituents in the United States. Report III, Coop. Inst. for Res., Colo. State Univ., Fort Collins, Colo., 2000

Mendonca, B. G., Local wind circulations on the slopes of Mauna Loa, J. Appl. Meteorol., 8, 533-541, 1969.

Mickley, L. J., P. Murti, D. Jacob, J. Logan, D. Koch, and D. Rind, Radiative forcing from tropospheric ozone calculated with a unified chemistryclimate model, J. Geophys. Res., 104, 30,135-30,172, 1999. 
Molnár, A., E. Mészáros, H. C. Hansson, H. Karlsson, A. Gelencsér, G. Y. Kiss, and Z. Krivácsy, The importance of organic and elemental carbon in the fine atmospheric aerosol particles, Atmos. Environ., 33, 2745-2750, 1999.

Myhre, G., F. Stordal, K. Restad, and I. S. A. Isaksen, Estimation of the direct radiative forcing due to sulfate and soot aerosols, Tellus, 50B, $463-477,1998$

Noone, K. J., and A. D. Clarke, Soot scavenging measurements in Arctic snowfall, Atmos. Environ., 22, 2773-2778, 1988.

Novakov, T., C. E. Corrigan, J. E. Penner, O. Rosario, and O. M. Bracero, Organic aerosols in the Caribbean trade winds: A natural source, J. Geophys. Res., 102, 21,307-21,313, 1997

Novakov, T., T. S. Bates, and P. K. Quinn, Shipboard measurements of concentrations and properties of carbonaceous aerosols during ACE-2, Tellus, 52B, 228-238, 2000.

Nunes, T. V., and C. A. Pio, Carbonaceous aerosols in industrial and coastal atmospheres, Atmos. Environ., 27A, 1339-1346, 1993.

Nyeki, S., U. Baltensperger, I. Colbeck, D. T. Jost, and E. Weingartner, The Jungfraujoch high-Alpine research station $(3454 \mathrm{~m})$ as a background clean continental site for the measurement of aerosol parameters, J. Geophys. Res., 103, 6097-6107, 1998

O'Dowd, C. D., M. H. Smith, and S. G. Jennings, Submicron particle, radon, and soot carbon characteristics over the northeast Atlantic, J. Geophys. Res., 98, 1123-1135, 1993.

Odum, J. R., T. P. W. Jungkamp, R. J. Griffin, R. C. Flagan, and J. H. Seinfeld, The atmospheric aerosol-forming potential of whole gasoline vapor, Science, 276, 96-99, 1997.

Ohta, S., and T. Okita, Measurements of particulate carbon in urban and marine air in Japanese areas, Atmos. Environ., 18, 2439-2445, 1984.

Ohta, S., and T. Okita, A chemical characterization of atmospheric aerosols in Sapporo, Atmos. Environ., 24A, 815-822, 1990.

Pandis, S. N., S. E. Paulson, J. H. Seinfeld, and R. C. Flagan, Aerosol formation in the photooxidation of isoprene and $\beta$-pinene, Atmos. Environ., 25A, 997-1008, 1991 .

Pankow, J. F., An absorption model of gas/particle partitioning of organic compounds in the atmosphere, Atmos. Environ., 28, 185-188, 1994a.

Pankow, J. F., An absorption model of gas/particle partitioning involved in the formation of secondary organic aerosol, Atmos. Environ., 28, 189 193, 1994b.

Parungo, F., C. Nagamoto, M. Zhou, A. Hansen, and J. Harris, Aeolian transport of aerosol black carbon from China to the ocean, Atmos. Environ., 28, 3251-3260, 1994.

Penner, J. E., H. Eddleman, and T. Novakov, Towards the development of a global inventory for black carbon emissions, Atmos. Environ., 27A $1277-1295,1993$.

Penner, J. E., C. A. Atherton, and T. E. Graedel, Global emissions and models of photochemically active compounds, in Global AtmosphericBiospheric Chemistry, edited by R. Prinn, pp. 223-248, Plenum, New York, 1994.

Penner, J. E., T. Wigley, P. Jaumann, B. Santer, and K. Taylor, Anthropogenic sulfate aerosols and climate change: A method for calibrating forcing, in Communicating About Climate: The Story of the Model Evaluation Consortium for Climate Assessment, edited by W. Howe and A. Henderson-Sellers, pp. 91-111, Gordon and Breach, Newark, N. J., 1997.

Penner, J. E., C. C. Chuang, and K. Grant, Climate forcing by carbonaceous and sulfate aerosols, Clim. Dyn., 14, 839-851, 1998.

Pham, M., J. F. Müller, G. P. Brasseur, G. Granier, and G. Megie, A 3d model study of the global sulfur cycle: Contributions of anthropogenic and biogenic sources, Atmos. Environ., 30, 1815-1822, 1996.

Piccot, S. D., J. J. Watson, and J. W. Jones, A global inventory of volatile organic compound emissions from anthropogenic sources, J. Geophys. Res., 97, 9897-9912, 1992.

Pinnick, R. G., G. Fernandez, E. Martinezandazola, B. D. Hinds, A. Hansen, and K. Fuller, Black carbon content and vertical structure to $7 \mathrm{~km}$ above sea-level, J. Geophys. Res., 98, 2651-2666, 1993.

Pio, C. A., L. M. Castro, M. A. Cequeira, I. M. Santos, F. Belchior, and M. L. Salqueiro, Source assessment of particulate air pollutants measured at the southern European coast, Atmos. Environ., 30, 3309-3320, 1996.

Polissar, A. V., Surface-level carbon-containing aerosol concentration in the North Atlantic, Izv. Acad. Sci. USSR, Atmos. Ocean. Phys. Engl. Transl., 28, 520-525, 1992.

Polissar, A. V., Measurements of the soot mass concentration and particlesize distribution of the atmospheric aerosol in the eastern Arctic, Izv Acad. Sci. USSR, Atmos. Ocean. Phys. Engl. Transl., 29, 66-73, 1993.

Polissar, A. V., P. K. Hopke, P. Paatero, Y. J. Kaufmann, D. K. Hall, B. A Bodhaine, E. G. Dutton, and J. M. Harris, The aerosol at Barrow, Alaska: Long-term trends and source locations, Atmos. Environ., 33, 2441-2458, 1999
Prather, M. J., Numerical advection by conservation of second-order moments, J. Geophys. Res., 91, 6671-6681, 1986

Puxbaum, H., J. Rendl, R. Allabashi, L. Otter, and M. C. Scholes, Mass balance of the atmospheric aerosol in a South African subtropical savanna (Nylsvley, May 1997), J. Geophys. Res., 105, 20,697-20,706, 2000.

Rasch, P. J., M. C. Barth, J. T. Kiehl, S. E. Schwartz, and C. M. Benkovitz, A description of the global sulfur cycle and its controlling processes in the National Center for Atmospheric Research Community Climate Model, Version 3, J. Geophys. Res., 105, 1367-1385, 2000.

Raunemaa, T., K. Kuuspalo, T. Alander, E. Tamm, A. Mirme, and V. Laine, Black carbon and aerosol in Boistö island, J. Aerosol Sci., 24, S29-S30, 1993.

Raunemaa, T., U. Kikas, and T. Bernotas, Observation of submicron aerosol, black carbon and visibility degradation in remote area at temperature-range from -24 to 20-degrees-C, Atmos. Environ., 28, 865871, 1994.

Rind, D., and J. Lerner, Use of on-line tracers as a diagnostic tool in general circulation model development, 1 , Horizontal and vertical transport in the troposphere, J. Geophys. Res., 101, 12,667-12,683, 1996.

Roelofs, G. J., J. Lelieveld, and L. Ganzeveld, Simulation of global sulfate distribution and the influence on effective cloud drop radii with a coupled photochemistry sulfur cycle model, Tellus, 50B, 224-242, 1998.

Ruellan, S., H. Cachier, A. Gaudichet, P. Masclet, and J.-P. Lacaux, Airborne aerosols over central Africa during the experiment for regional sources and sinks of oxidants (EXPRESSO), J. Geophys. Res., 104, 30,673-30,690, 1999 .

Sander, R., Compilation of Henry's law constants for inorganic and organic species of potential importance in environmental chemistry (version 3), http://www.mpch-mainz.mpg.de/sander/res/henry.html, 1999.

Saxena, P., and L. M. Hildemann, Water-soluble organics in atmospheric particles: A critical review of the literature and application of thermodynamics to identify candidate compounds, J. Atmos. Chem., 24, 57109,1996

Schult, I., J. Feichter, and W. F. Cooke, Effect of black carbon and sulfate aerosols on the global radiation budget, J. Geophys. Res., 102, 30,107$30,117,1997$

Seinfeld, J. H., G. B. Erdakos, W. E. Asher, and J. F. Pankow, Modeling the formation of secondary organic aerosol (SOA), 2, The predicted effects of relative humidity on aerosol formation in the $\alpha$-pinene-, $\beta$-pinene-, sabinene-, $\delta^{3}$-carene-, and cyclohexene-ozone systems, Environ. Sci. Technol., 35, 1806-1817, 2001.

Shu, Y., and R. Atkinson, Atmospheric lifetimes and fates of a series of sesquiterpenes, J. Geophys. Res., 100, 7275-7281, 1995.

Smith, D. J. T., R. M. Harrison, L. Luhana, C. A. Pio, L. M. Castro, M. N. Tariq, S. Hayat, and T. Quraishi, Concentrations of particulate airborne polycyclic aromatic hydrocarbons and metals collected in Lahore, Pakistan, Atmos. Environ., 30, 4031-4040, 1996.

Taylor, K. E., and J. E. Penner, Response of the climate system to atmospheric aerosols and greenhouse gases, Nature, 369, 734-737, 1994

Tegen, I., D. Koch, A. A. Lacis, and M. Sato, Trends in tropospheric aerosol loads and corresponding impact on direct radiative forcing between 1950 and 1990: A model study, J. Geophys. Res., 105, 26,97126,989, 2000

Toon, O. B., J. B. Pollack, and B. N. Khare, The optical constants of several atmospheric aerosol species: Ammonium sulfate, aluminum oxide, and sodium chloride, J. Geophys. Res., 81, 5733-5748, 1976.

Turpin, B. J., P. Saxena, and E. Andrews, Measuring and simulating particulate organics in the atmosphere: Problems and prospects, Atmos. Environ., 34, 2983-3031, 2000.

Wang, S., S. E. Paulson, D. Grosjean, R. C. Flagan, and J. H. Seinfeld, Aerosol formation and growth in atmospheric organic/ $\mathrm{NO}_{x}$ systems, I, Outdoor smog chamber studies of $\mathrm{C}_{7^{-}}$and $\mathrm{C}_{8}$-hydrocarbons, Atmos. Environ., 26A, 403-420, 1992.

Wang, Y., D. J. Jacob, and J. A. Logan, Global simulation of tropospheric $\mathrm{O}_{3}-\mathrm{NO}_{x}$-hydrocarbon chemistry, 1, Model formulation, J. Geophys. Res., 103, 10,713-10,725, 1998a.

Wang, Y., J. A. Logan, and D. J. Jacob, Global simulation of tropospheric $\mathrm{O}_{3}-\mathrm{NO}_{x}$-hydrocarbon chemistry, 2, Model evaluation and global ozone budget, J. Geophys. Res., 103, 10,727-10,755, $1998 \mathrm{~b}$.

Wang, Y., J. A. Logan, and D. J. Jacob, Global simulation of tropospheric $\mathrm{O}_{3}-\mathrm{NO}_{2}$-hydrocarbon chemistry, 3, Origin of tropospheric ozone and effects of nonmethane hydrocarbons, J. Geophys. Res., 103, 10,757$10,767,1998 \mathrm{c}$

Wesely, M. L., Parameterization of surface resistances to gaseous dry deposition in region-scale numerical models, Atmos. Environ., 23, $1293-$ 1304, 1989.

Wesely, M. L., and B. B. Hicks, Some factors that affect the deposition rates of sulfur dioxide and similar gases in vegetation, J. Air Pollut. Control Assoc., 27, 1110-1116, 1977. 
Wolff, E. W., and H. Cachier, Concentrations and seasonal cycle of black carbon in aerosol at a coastal Antarctic station, J. Geophys. Res., 103, 11,033-11,041, 1998.

Wolff, G. T., M. S. Ruthkosky, D. P. Stroup, P. E. Korsog, M. A. Ferman, G. J. Wendel, and D. H. Stedman, Measurements of $\mathrm{SO}_{\mathrm{x}}, \mathrm{NO}_{\mathrm{x}}$, and aerosol species on Bermuda, Atmos. Environ., 20, 1229-1239, 1986.

Yaaqub, R. R., T. D. Davies, T. D. Jickells, and J. M. Miller, Trace-elements in daily collected aerosols at a site in southeast England, Atmos. Environ., 45A, 985-996, 1991

Yu, J. Z., D. R. Cocker, R. J. Griffin, R. C. Flagan, and J. H. Seinfeld, Gas- phase ozone oxidation of monoterpenes: Gaseous and particulate products, J. Atmos. Chem., 34, 207-258, 1999.

Zappoli, S., et al., Inorganic, organic, and macromolecular components of fine aerosols in different areas of Europe in relation to their water solubility, Atmos. Environ., 33, 2733-2743, 1999.

S. H. Chung and J. H. Seinfeld, Department of Chemical Engineering, California Institute of Technology, Pasadena, CA 91125, USA. (seinfeld@ caltech.edu; serenac@caltech.edu) 